T.А. Орнацкая

\title{
ИСТОРИЧЕСКИЙ ОПЫТ ПРАВОВОГО ПРОСВЕЩЕНИЯ \\ НА ДАЛЬНЕМ ВОСТОКЕ РОССИИ \\ (1917-1941 гг.)
}

Монография

Владивосток

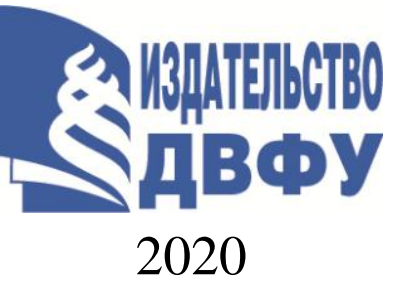




\section{Рецензенты:}

В.В. Синиченко, доктор исторических наук, профессор; М.В. Полянский, кандидат исторических наук

\section{Орнацкая, Татьяна Александровна.}

O-68 Исторический опыт правового просвещения на Дальнем Востоке России (1917-1941 гг.) : монография / Т.А. Орнацкая. Владивосток : Изд-во Дальневост. федерал. ун-та, 2020. - 190 с. ISBN 978-5-7444-4901-8.

DOI dx.doi.org/10.24866/7444-4901-8.

В монографии на основе широкого круга источников анализируется исторический опыт правового просвещения на Дальнем Востоке России в 1917-1941 гг. В работе рассматриваются теоретические подходы к изучению правового просвещения; исследуются этапы становления советской системы правового просвещения; анализируются особенности правового просвещения в системе профессиональной подготовки сотрудников дальневосточных государственных органов; изучается процесс формирования правовой культуры сотрудников органов милиции Дальнего Востока.

$$
\text { УДК } 378
$$

ББК 74.03

(C) Орнацкая T.A., 2020

ISBN 978-5-7444-4901-8 О Оформление. ФГАОУ ВО ДВФУ, 2020 


\section{ВВЕДЕНИЕ}

Система образования и просвещения - ключевые составляющие в обеспечении исторического воспроизводства общества. Страны создают их в соответствии с историей, традициями, культурой и национальными особенностями. 1990-е годы стали значимой вехой в истории России. Кардинальные преобразования, пережитые нашей страной привели к всплеску востребованности защиты законных интересов и прав граждан во всех отраслях российского права, что способствовало увеличению интереса населения к юридическим знаниям. Знание права вновь стало востребованным.

В постсоветской России сфера применения правовых знаний значительно расширилась. Появились новые профессии, тесно связанные с юриспруденцией, но для замещения вакансии, не требующие юридического образования, поэтому ключевую роль стало играть правовое просвещение. Вместе с тем постоянно меняющееся отечественное законодательство требует понимания основных принципов права, осознания ключевой роли закона в общественной жизни, готовности к постоянному обучению и расширению своих знаний, поэтому юридические знания являются одними из важных для современного человека.

В настоящее время правовое просвещение широко распространено. Оно осуществляется не только на государственном и муниципальном уровнях, но и реализуется средствами массовой информации, 
коммерческими и общественными организациями. В Российской Федерации правовое просвещение способствует решению задач государственного строительства, преодолевая правовой нигилизм содействует осознанному отношению граждан к праву и закону, позволяет повысить уровень правовой культуры общества и поэтому занимает особое место в образовательном комплексе страны.

Отечественная историография проблемы правового просвещения на Дальнем Востоке России 1917-1941 гг. обладает определенными особенностями. К числу специфических черт, характеризующих ее развитие следует отнести плавное повышение интереса специалистов к теоретическим проблемам, постепенное расширение проблематики темы, системный поиск учеными новых подходов к изучению ее отдельных сюжетов с применением междисциплинарных подходов, расширением и новым прочтением источниковой базы. К настоящему времени отечественными и иностранными учеными освещен широкий спектр вопросов, связанных с историей правового просвещения в нашей стране. Историография имеет в своем арсенале научно значимые труды и оригинальные научные публикации. Внимание исследователей уделено истории просвещения сотрудников милиции и, частично, анализу деятельности небольшевистских властей.

Анализ литературы показывает, что история отечественного правового просвещения 1917-1941 гг. включает в себя два периода: советский и постсоветский.

Советский период общероссийской историографии исследования условно можно разделить на 4 этапа: 
1 этап (октябрь 1917 - конец 1922 г.). Первые постреволюционные годы в общероссийском масштабе связаны не только с Гражданской войной в России, но и с разрушением существовавших государственных и общественных институтов. История этого периода отражена в работах современников событий, однако появился и первый советский учебник по истории России ${ }^{1}$. Система просвещения подверглась кардинальному реформированию. Идеологами изменений в соответствии с советской концепцией выступали Н.К. Крупская, А.В. Луначарский и М.Н. Покровский.

Исследовательская деятельность по изучению теоретических аспектов права и правового просвещения в эти годы за исключением единичных работ не проводилась ${ }^{2}$. Прежде всего это связано с тем, что в условиях гражданской войны запросы быстроменяющегося общества не распространялись на аналитические работы. На наш взгляд, слабый интерес центральной печати к правовому просвещению связан с широким освещением событий Гражданской войны и борьбы с интервенцией, трудностей становления советской власти, поэтому вопросы внутренней жизни отходили на второй план.

2 этап (1923 г. - конец 1920-х гг.) характеризуется завершением Гражданской войны, укреплением советской власти в СССР, началом масштабных экономических

${ }^{1}$ Болдырев В.Г. Из пережитого // Сибирские огни. 1922. №№ 56; 1924. № 1; Покровский М.Н. Русская история в самом сжатом очерке. М., 1920-1923.

${ }^{2}$ Гойхбарг А.Г. Пролетарская революция и гражданское право // Пролетарская революция и право. 1918. № 1. С. 12-19; Звягинцев Е.А. Словарь внешкольнаго образованія М., 1918. 
изменений, а также окончательным формированием однопартийной системы. $\mathrm{B}$ рассматриваемый этап появились первые обобщающие работы по истории гражданской войны и военной интервенции в России ${ }^{3}$, изучающие вклад советской власти в культурное развитие народных масс ${ }^{4}$. Отечественная педагогическая наука переживала всплеск своего развития. Активно работали и занимались теоретической проработкой своих идей А.С. Макаренко, П.Ф. Каптерев, С.Т. Шацкий и др. Их труды могут одновременно рассматриваться и как исторический источник по истории образовательного и воспитательного процессов, т.к. они содержат идеи, которые активно внедрялись по всей стране.

Этап связан с провозглашением на X съезде РКП (б) новой экономической политики и, как следствие, увеличением роли права в общественной жизни. Это обусловило интерес специалистов-правоведов к советскому пониманию права, законности, а также вопросам распространения знаний о советских правовых нормах среди населения $\mathrm{CCCP}^{5}$. Правоведы-теоретики в своих научных

${ }^{3}$ Венцов С., Белинский С. Красная гвардия. М., 1924; Парфенов (Алтайский) П.С. Гражданская война в Сибири. 1918-1920 М., 1925; Пишон. Союзническая интервенция на Дальнем Востоке и в Сибири. М.-Л., 1925 и др.

4 Кабо Е.О. Очерки рабочего быта (Опыт монографического исследования рабочего быта). М., 1928; Янковский М. За нового человека. (О борьбе молодежи за культуру). Л., 1928 и др.

5 Трайнин А.Н. О революционной законности // Право и жизнь. 1922 № 1. С. 5-8; Бранденбургский Я.Н. Просто законность или революционная законность? //Еженедельник советской юстиции. 1922. № 31-32. С.1-2; Рейснер М.А. Наше право. Чужое право. Общее право. М.-Л., 1926; Ростовский И. Правовое просвещение и изба-читальня: 
трудах рассуждали о революционной законности и содержании права, а юристы-практики писали о необходимости распространения среди населения элементарных знаний о правовых нормах действующих в стране $^{6}$. Все они, выражая отрицательное отношение к правовой системе Российской империи, были единодушны в том, что советские правовые нормы должны являться одним из регуляторов общественных отношений. Однако конструкция и смысловое содержание этих норм ими не обсуждались, а общая концепция исследований базировалась на понимании прогрессивности советского права.

Постепенно утверждавшийся в стране классовопартийный подход сказывался и на публикациях. Все чаще стали печатать статьи научно-публицистического характера. На страницах советской печати разворачивались идеологические «бои» по вопросам методов построения социализма. Идея полезности юридических знаний для нужд социалистических преобразований стала предметом дискуссии ${ }^{7}$.

Таким образом, второй этап советской историографии связан с развитием публицистической и зарождением советской научно-публицистической литературы, началом теоретического осмысления советского права, правового

материалы и их проработка для шести занятий (руководство для юридических бюро, кружков и справочных столов). М., 1927 и др.

6 Эратов Л. К ликвидации правовой безграмотности // Еженедельник советской юстиции. 1922. № 8. С. 8-9; Санчев В. Очередная задача Наркомюста // Еженедельник советской юстиции. 1922. № 11. С. 7; Иорданский Н.Н. Основы и практика социального воспитания. М., 1923 и др.

7 Бехтерев Ю. К вопросу о подготовке работников исправительно-трудового дела // Административный вестник. 1926. № 11. С. 32-36 и др. 
обучения и воспитания, поиском эффективных методов их практического распространения среди населения страны. Основной целью авторов было через высказывание своих взглядов на существовавшие проблемы воздействовать на читателя, что в целом соответствовало марксистской методологии. Содержание советского правового просвещения не являлось предметом научного обсуждения, т.к. оно находилось в стадии своего становления. Большая часть работ не имела аналитического характера, а лишь констатировала происходившие в стране перемены, вызывая диалектические споры о дальнейшем развитии советского права.

3 этап (1930-е - 1945 гг.) определяется кардинальным переустройством страны, существованием административнокомандной системы, а также дальнейшим распространением марксистской методологии, и как следствие, признанием определяющей роли экономического строя по отношения к правовым нормам. Стали выпускаться обобщающие работы по истории нашей страны ${ }^{8}$. Важным событием в отечественной педагогической науке стал завершившийся к 1930 г. выпуск «Педагогической энциклопедии» ${ }^{9}$. В ней обобщено представление о советской методологии и методике преподавания, содержится богатый понятийный аппарат связанный с советской психологией и педагогикой 1930-х гг., раскрыты формы подготовки советских кадров и т.д. На долгие годы этот научный труд стал базой для всей системы отечественного образования.

${ }^{8}$ История гражданской войны в СССР / Под ред. М. Горького, В. Молотова и др. М., 1936; Генкина Э.Б. Курс истории СССР. М., 1938 и др.

9 Педагогическая энциклопедия / Под ред. А.Г. Калашникова. Тт. 1,3. М., 1930. 
В рассматриваемый этап продолжился выпуск публицистических статей о советском праве. В прессе начала 1930-х гг. широко освещались проводившиеся всесоюзные совещания, посвященные вопросам правового просвещения ${ }^{10}$. Эти публикации в условиях укрепления административнокомандной системы создавали иллюзию главенства в стране норм социалистического права. Практика была сопряжена с борьбой с «врагами народа», а в реалии - с юристами, «не стоящими на марксисткой основе» ${ }^{11}$.

Провозглашенная руководством страны в середине 1930-х гг. популяризация советского законодательства положительно сказалась на правовом просвещении граждан. Редакторы журналов «Заочник-юрист», «Советская юстиция», «Социалистическая законность» и других, принимая посыл и директивы советского руководства о распространении знаний о советском праве пересмотрели концепцию изданий поставив во главу угла потребности читателя. Лица, ответственные за подготовку выпусков нередко вступали в переписку с подписчиками и отвечали на интересующие адресантов вопросы.

В рассматриваемый период появились первые аналитические статьи и монографии по проблемам формирования советского права ${ }^{12}$. Авторы анализировали

10 Совещание в Прокуратуре Союза ССР с районными следователями // Социалистическая законность. 1936. № 7. С. 73-83; Всесоюзное совещание по вопросам юридического образования // Социалистическая законность. 1938. № 7. С. 99-101 и др.

${ }_{11}$ Иезуитов В., Резунов М. Назревшая реформа // Советское государство и революция права. 1930. № 3. С. 142-146 и др.

12 Ундервич В. Борьба за суд пролетарской диктатуры в первые месяцы Октябрьской революции // Советское государство и революция права. 1931. № 7. С. 58-76; № 8. С. 58-79; Сизонов К.П. Основы советского 
этот процесс с классовых позиций и не только признавали ключевую роль коммунистической партии в формировании советских правовых норм, но и видели в этом личные заслуги В.И. Ленина и И.В. Сталина. Такой подход к изучению исторического прошлого становления советской правовой системы отражал существовавшее идеологическое влияние.

Начало Великой Отечественной войны не приостановило публицистическую и исследовательскую работу, однако фокус изысканий концентрировался вокруг решения проблем изучения юриспруденции в условиях вооруженного противостояния ${ }^{13}$. В этот сложный для страны период борьбы с врагом авторы освещали изменение задач, стоявших перед правовым просвещением, предлагали новые методы обучения специалистов.

Таким образом, третий этап советской историографии тесно связан с условиями политической жизни страны в рассматриваемый период. Право стало выступать инструментом политической борьбы, а распространение марксистской методологии привело к полному подчинению теоретической юриспруденции требованиям партийноидеологической системы. Обучение специалистов в области советского права осуществлялось исходя из запросов социалистического общества. Подходы к изучению советского правового воспитания только формировались. Большинство

права и этапы его развития М., 1933; Крыленко Н.В. Советское правосудие. Суд и прокуратура в СССР. М., 1937 и др.

13 Судариков Н., Финкельштейн Б. Пути юридического образования // Советская юстиция. 1941. № 3. С. 12-15; Красногорский М. Готовить кадры юристов темпами военного времени // Социалистическая законность. 1941. № 7-8. С. 14-16 и др. 
работ носило публицистический характер, что обусловлено особенностями исторического периода. Вместе с тем рассматриваемый этап богат научными идеями и дискуссиями, которые сформировали базу для будущих преобразований.

4 этап (1945 г. - середина 1980-х гг.) характеризуется складыванием основного массива обобщающих работ по истории советского периода нашей страны ${ }^{14}$, ее культурного развития ${ }^{15}$, вкладе партийных структур в культурную революцию $^{16}$, а также отечественной и зарубежной историографии, затрагивающей вопросы правового просвещения. Его особенностями являются широкая проблематика, постепенный отход от идеологических фреймов, привлечение широкого круга источников, а также увеличение количества работ, имеющих аналитический характер. Изменение политического климата в послевоенное время частично способствовало пересмотру тактики выбора и анализа исторических фактов. Ученые стали отходить от установок «краткого курса», однако на протяжении длительного времени в историографии изучаемой темы сохранялась идеологическая догматика.

Продолжилось теоретическое изучение отечественного

${ }^{14}$ Краев М.А. Победа колхозного строя в СССР. М., 1954; СССР в период восстановления народного хозяйства (1921-1925 гг.) / Под ред. А.П. Кучкина. М., 1955; Минц И.И. История Великого Октября: в 3 тт. М., 1967-1973; Городецкий Е.Н. Рождение Советского государства. М., 1987 и др.

15 Лебедев П.И. Советское искусство в период иностранной военной интервенции и гражданской войны. М.-Л., 1949; Ермаков В.Т. Исторический опыт культурной революции в СССР. М., 1968 и др.

16 Ким М.П. Коммунистическая партия - организатор культурной революции в СССР. М., 1955; КПСС во главе культурной революции в СССР. М., 1972 и др. 
образования. Период связан с разработкой новых концепций педагогики, психологии и методики преподавания с опорой на историческую ретроспективу. Это не только актуализировало публикацию трудов государственных деятелей, участвовавших в 1920-х годах в формировании советской системы образования ${ }^{17}$, но и способствовало анализу ответственного педагогического наследия ${ }^{18}$. В научных публикациях уделялось внимание роли педагогики в практике социалистического строительства, укреплению связи школы с жизнью, а также модели организации советской системы образования.

Этап связан с началом научного изучения ведомственного образования ${ }^{19}$. Исследования также не лишены идеологической направленности, однако ученым впервые на основе архивных материалов центральных и региональных архивов, посвященных становлению правового просвещения милиционеров. Характерной чертой публикаций стало стремление показывать не только положительные итоги деятельности советских и партийных

${ }^{17}$ Крупская Н.К. Педагогические сочинения в 10 томах. М., 1958; Луначарский А.В. О классовой школе // А.В. Луначарский о народном образовании. Сборник / ред.: Н.К. Гончаров, Н.А. Константинов, Ф.Ф. Королев. М., 1958. С. 95-118; Покровский М.Н. Избранные произведения в четырех книгах М., 1967; Блонский П.П. Избранные педагогические сочинения в 2-х томах М., 1979 и др.

18 Медынский Е.М. Просвещение в СССР М., 1955; Миловидов А.С. Коммунистическая нравственность и военнопатриотическое воспитание. М., 1979 и др.

${ }^{19}$ Николаев П.Ф. Школы-резервы милиции СССР в 1921-1925 гг. // Научные труды. Научные труды Омской высшей школы милиции МВД СССР. Омск, 1965. Вып. 5. С. 347-358; Гольдман В.С. Из истории организации школ и курсов милиции РСФСР в 1917 - 1925 годах // Труды высшей школы МООП СССР. М., 1968. Вып. 20. С. 80-98 и др. 
структур, но и объективно оценивать их работу.

Таким образом, в рассмотренный период полностью отсутствовали публицистические работы освещающие изучаемую тему. Разработка темы правового просвещения отличалась стремлением к научному осмыслению составляющих ее проблем.

С начала 1990-х гг. и по настоящее время наблюдается расширение диапазона в изучении проблемы правового просвещения обусловленное плюрализмом методологических трактовок и свободой толкования общественных явлений. Рассматриваемый период существенно превосходит числом исследователей предшествующее время. Продолжается изучение различных аспектов истории Отечества периода 19171941 гг. $^{20}$, развития советской культуры ${ }^{21}$ и направлений, связанных с проблемой правового просвещения, появляются исследования по смежной тематике.

Система советского образования стала предметом исследования не только педагогов, но и специалистов почти всех гуманитарных наук. В публикациях поставлены и изучены проблемы сущности воспитательного процесса. Сделанные учеными выводы стали основой для дальнейших междисциплинарных исследований.

Расширение тематики исследований, характерное для

20 Лукин Ю.Ф. Из истории сопротивления тоталитаризму в СССР (20-80-е годы). М., 1992; Зимина В.Д. Белое движение и российская государственность в период Гражданской войны. Волгоград, 1997 и др.

21 Горяева Т.М. Радио России: политический контроль советского радиовещания в 1920-1930-х гг. Документированная история. М., 2000и др. 
постсоветского этапа затронуло и тему правового просвещения. Широко распространенными стали научноисследовательские статьи связанные с пониманием права в первые годы советской власти ${ }^{22}$. Авторы рассматривают устоявшиеся концепты с новых методологических позиций и единодушны в том, что советское правопонимание прошло сложный путь от полного отрицания норм права, до их возвеличивания к началу 1930-х годов. Эти публикации предоставляют исследователю возможность проследить динамику преемственности правовых норм в период с октября 1917 г. до конца 1930-х гг.

Открывшийся в Российской Федерации доступ к архивным материалам позволил ученым приступить к более углубленному изучению истории советской милиции, особенно ранее практически закрытого для изучения периода 1917-1930-х гг. ${ }^{23}$. Для опубликованных в этот период научных

22 Евдеева Н.В. Правосознание и правопонимание: динамика взаимодействия // Современное право. 2007. № 7. С. 48-52; Кабаненко М.C. Деформация теоретического (доктринального) правосознания: период становления советского права // Юридическая наука и практика. 2011. Т. 7. С. 34-43; Мороз Е.В. Отечественное правопонимание 1920-х гг. (некоторые аспекты проблемы) // Право и образование. 2012. № 11. С. 146-155; Шабанова И.К. От права пролетарского к праву социалистическому: метаморфоза советских правовых установок // Академический вестник. 2013. № 1 (23). С. 78 87; Жуков В.Н. Марксистская социология права первых лет советской власти: М.А. Рейснер, П.И. Стучка, Е.Б. Пашуканис // Право и государство: теория и практика. 2014. № 1 (109). С. 43-53; Его же. Право, государство, закон: трактовка советских юристов 1920-х годов // Аграрное и земельное право. 2015. № 8 (128). С. 20-27 и др.

23 Крапивина И.С. Система подбора, расстановки, профессиональной подготовки и воспитания кадров советской милиции в 1930-е годы // Ученые записки Санкт-петербургского им. В.Б. Бобкова филиала Российской таможенной академии. 1997. № 2 
статей характерен неконъюнктурный исторический анализ, взвешенный и объективный подход, отсутствие односторонней трактовки происходивших процессов. Авторы впервые стали изучать процессы организационного становления и правового регулирования отечественного профессионального образования, освещать вопросы, связанные с образовательным правом, рассматривать историю и методологию отечественного права как науки, а также вопросы милицейской кадровой политики и правовой подготовки. Несмотря на то, что исследователи не касались истории правового просвещения на Востоке России, их работы дополняют картину обучения специалистов и просвещения населения в области права, позволяя комплексно рассмотреть проблемы правового просвещения для Дальневосточного региона.

(4). С. 220-237; Макеев А. Формирование системы профессиональной подготовки кадров милиции в 1930-е гг., особенности кадровой политики в регионах (историко-правовой аспект) // Юридическая мысль. 2002. № 3 (9). С. 9-21; Олейник И.И. Организация и результаты юридической подготовки работников правоохранительных органов в Советском государстве (1917-1941 гг.) // Вестник Владимирского юридического института. 2008. № 2 (7). С. 259-264; Степанов М.М. Особенности милицейского образования в России в годы гражданской войны (1918-1920 гг.) // Ленинградский юридический журнал. 2011. № 1. С. 101-108; Колемасов В.Н. Организация профессиональной подготовки сотрудников милиции России в 1920-е годы // Новый юридический журнал. 2012. № 2. С. 175-179; Токарева С.Н. Общеюридическая подготовка советских милиционеров в 1920-е годы // Вестник Воронежского института МВД России. 2013. № 3. С. 199202; Синиченко В.В., Карнович С.А. Становление милицейского образования в Восточной Сибири в 20-х годах XX века // Социальногуманитарные проблемы деятельности ОВД. 2015. № 1 (72). С. 65-76; Кожевина М.А. «Неттелбалдтова система» или Чему учили первых российских правоведов // Научный вестник Омской академии МВД России. 2008. № 1. С. 34 - 40 и др. 
Дальневосточная

правового о просвещения на Дальнем Востоке России не так обширна, как общероссийская. Она ведет свое начало с 1970-х гг. появлением работ, посвященных истории становления советской власти в регионе ${ }^{24}$, описывавших проблемы культурного развития населения, в том числе и через призму работы партийных органов ${ }^{25}$, формирования местных милицейских структур и органов юстиции ${ }^{26}$. Основой публикаций стали не только труды классиков марксизма-ленинизма, решения партийных съездов и выступления высших партийных руководителей, но и документальные источники. Авторы, обращаясь к проблемам становления системы профессионального обучения на местах, обратили внимание на особенности процесса просвещения в местностях Дальнего Востока. Анализируя исследования этого периода необходимо

${ }^{24}$ Шиндялов Н.А. Первые шаги по пути социализма (1922-1926) Благовещенск, 1972; Флеров В.С. Дальний Восток в период восстановления народного хозяйства. Томск, 1973; Исаева Т.С., Сонин В.В. Из истории развития советской государственности на Дальнем Востоке. 1922-1926. Владивосток, 1974; История Дальнего Востока СССР. Владивосток, 1976 и др.

25 Из истории социалистического и коммунистического строительства на Дальнем Востоке СССР (1917-1975 гг.) Владивосток, 1976; Кузнецов М.С. Борьба партийных организаций Дальнего Востока за становление советской культуры (1922-1927 гг.) Томск, 1978 и др.

${ }^{26}$ Ходасевич А.П. Милиция таежного края. Очерк. Хабаровск, 1969; Козуров В.В. Правовые основы организации и деятельности народной милиции Дальневосточной республики (1920-1922 гг.) // 50 лет СССР и развитие советского государства и права. Омск, 1973; Бакалейников П.С. Становление камчатской милиции (1918-1922 гг.) // История социалистического строительства на Камчатке. Владивосток, 1979 и др. 
подчеркнуть, что несмотря на идейную выдержанность они богаты архивным материалом и для них характерен выход на краеведческую тематику. Вместе с тем, тема правового просвещения в ведомственном образовании в них освещена недостаточно, а проблемы просвещения населения освещены лишь через призму партийносоветского знания.

Современная историография ознаменована всплеском исследований по истории Дальнего Востока России ${ }^{27}$. Изучая различные аспекты прошлого региона ученые рассматривали проблемы культуры, образования и просвещения $^{28}$. В монографиях и научных статьях сделаны важные выводы о процессе зарождения правового просвещения.

Активный поиск новых подходов к изучению и оценке событий прошлого, освобождение от идеологического диктата и догматичности способствовали изучению малоисследованных исторических направлений. Свой вклад в изучение темы правового просвещения в небольшевистских режимах внесли ученые,

27 Сонин В.В. Великий Октябрь и становление советской государственности на Дальнем Востоке (1917-1922) Владивосток, 1987; Дальний Восток России в период революций 1917 года и гражданской войны. Владивосток, 2003; Ципкин Ю.Н. Антибольшевистские режимы на Дальнем Востоке России в период гражданской войны (1917-1922 гг.) Хабаровск, 2003 и др.

28 Березкина Н.И., Гуменюк Ф.И., Ткалич А.П. От неграмотности ко всеобщему среднему образованию. Исторический очерк развития образовательной и профессиональной школы в 19171987 годах. Владивосток, 1991 и др. 
занимающиеся изучением Гражданской войны ${ }^{29}$.

Значительный вклад в разработку тематики дальневосточного милицейского просвещения принадлежит Р.А. Воробьеву и Н.А. Шабельниковой ${ }^{30}$. Основой их работ стали материалы центральных, региональных и ведомственных архивов, документы из фондов музея Дальневосточного юридического института МВД России, воспоминания ветеранов и литературные материалы. Вместе с тем в рассматриваемых работах изучение милиционерами юриспруденции рассматривается косвенно, обойдена вниманием обширная тематика правового просвещения дальневосточных милиционеров.

Зарубежная историография темы правового просвещения в России и на Дальнем Востоке в изучаемый период представлена слабо, недостаток интереса исследователей, полагаем, связан с узостью источниковой базы иностранных архивов.

Анализ литературы по исследуемой проблеме свидетельствует о всплеске интереса ученых к вопросам просвещения в целом, в том числе и правового в общероссийском масштабе. Обширен пласт дальневосточной

29 Звягин С.П. Правоохранительная политика А.В. Колчака. Кемерово, 2001.

${ }^{30}$ Воробьев Р.А. Советская милиция Приамурья (1917-1925 гг.) Хабаровск, 1989; Шабельникова Н.А. Милиция Дальнего Востока России (1922-1930 гг.) Владивосток, 2018; Ее же. Подготовка кадров дальневосточной милиции в 20-е годы // Вопросы истории Дальнего Востока : межвузовский сб. науч. статей. Вып. 3 (8). Ч. 2. Хабаровск, 2001; Шабельникова Н.А., Бакшутов С.Н. Формирование системы профессионального обучения кадров милиции на Дальнем Востоке России в 1920-е гг. // Теория и практика общественного развития. 2015. № 21. С. 182-185 и др. 
историографии. Предметом научного интереса специалистов являются особенности реализации советских правовых норм, а также проблемы подготовки кадров для правоохранительных органов. Вместе с тем изучение и осмысление истории правового просвещения на Дальнем Востоке России до настоящего времени комплексно не проведено. Полностью отсутствуют исследования, освещающие процесс правового просвещения специалистов суда и прокуратуры, государственных структур, не изучены направления и содержание правового просвещения дальневосточников. Таким образом требуется более глубокое осмысление исторического опыта развития правового просвещения на Дальнем Востоке России в 1917-1941 гг.

Работа над исследованием потребовала скрупулезного выявления и изучения различных исторических источников. Все использованные источники были классифицированы по форме на письменные (опубликованные в открытой печати и архивные материалы) и произведения искусства (зрелищноигрового, изобразительного, декоративно-прикладного).

По функциональным особенностям письменные опубликованные источники можно разделить на 5 групп:

- правовые акты, составляющие законодательную базу советской власти;

- партийные документы и материалы, директивы, политические сочинения руководителей партии и правительства по вопросам правового просвещения;

- материалы (статьи и публикации) по научным дискуссия, затрагивающим сферу правового просвещения; 
- материалы периодической печати;

- источники личного происхождения.

Первая группа письменных источников представлена сборниками документов, отдельными правовыми актами и хронологически инкорпорированными материалами, освещающие государственную политику в области советского просвещения, в т.ч. правового ${ }^{31}$.

Ocобое направление составляют ведомственные правовые акты, в которых содержится информация о правовом просвещении сотрудников милиции и юстиции $^{32}$. В сборниках документов содержатся сведения, разъясняющие требования к уровню образовательной подготовки служащих, чья деятельность предполагала понимание советского законодательства.

Эту группу дополняют сборники, отражающие результаты правотворческой деятельности буферного государства Дальневосточной республики и дальневосточных советских

31 Декреты Советской власти. Тт. 1-12. М., 1957-1986; Собрание узаконений и распоряжений правительства за 1917-1918 гг. М., 1942; Собрание узаконений и распоряжений Рабочего и Крестьянского правительства РСФСР. М., 1917-1938; Собрание узаконений и распоряжений Рабочего и Крестьянского правительства СССР. М., 1922-1937; Собрание постановлений правительства СССР. М., 1938 1991 гг.; Постановления IX Всероссийского съезда Советов. М., 1921; О системе заочного обучения: постановление СНК РСФСР от 3 марта 1931 г. // Бюллетень Народного комиссариата по просвещению РСФСР. 1931. № 10, ст. 150; О подготовке научных и научнопедагогических работников: постановление СНК СССР от 13 января 1934 г. // Известия ЦИК и ВЦИК СССР. 1934. 14 янв. и др.

32 Сборник приказов и циркуляров Главного управления рабочекрестьянской милиции при СНК РСФСР. 1931-1932; Сборник приказов прокуратуры Союза ССР действующих на 1 декабря 1938 г. / под ред. А.Я. Вышинского. М., 1939 и др. 
государственных структур ${ }^{33}$. Изучение данного вида источников позволяет понять особенности Гражданской войны на Дальнем Востоке, рассмотреть процесс становления советской власти в регионе, проанализировать роль руководителей Дальневосточного региона в развитии правового просвещения сотрудников правоохранительных органов и населения.

В целом, оценивая данную группу источников, следует обратить внимание на то, что именно нормативные правовые документы являлись руководящими для центральных, региональных и ведомственных структур, формируя контуры их повседневной деятельности. Однако в некоторых случаясь, они носили декларативный характер, учитывая значительный объем принимаемых законов в изучаемый период, и поиск концепции просвещения в соответствии с нормами советского права.

Вторую группу письменных исторических источников составляют партийные документы и материалы, директивы $^{34}$, политические сочинения ${ }^{35}$ по вопросам правового просвещения.

${ }^{33}$ Собрание узаконений и распоряжений правительства ДВР: в 2-х частях. Чита, 1921-1922; Дальревком. Сб. постановлений. Чита, 1922; Собрание узаконений и распоряжений правительства ДВР: в 2-х частях. Чита, 1921-1922; Дальсовнарком. 1917-1918 гг. Сб. док. и материалов. Хабаровск, 1969; Первый Совдеп: документы и материалы о Петропавловском Совете рабочих и крестьянских депутатов. Петропавловск-Камчатский, 1967 и др.

34 Решения партии и правительства по хозяйственным вопросам (1917-1967 гг.) М., 1967; Коммунистическая партия Советского Союза в резолюциях и решениях съездов, конференций и пленумов ЦК (1898-1986). Т. 4. 1926-1929 гг. М., 1984; О работе РКП в деревне (Постановление ЦК РКП во исполнение решений XII Съезда РКП) Тюмень, 1923; О популяризации советского законодательства: 
Партийные документы в исторических условиях изучаемых хронологических рамок являлись источниками права, т.к. соответствуют признакам нормы права (общеобязательность, формальная определенность, системность и иерархичность, неоднократность, обеспечение исполнения силой принуждения). Они способствуют уяснению вопросов, связанных с особенностями политической и правовой организации советского общества. В силу того, что за коммунистической партией закреплялась роль «руководящей и направляющей силы» эти материалы представляют интерес и научно-значимый материал для современного изучения советской государственности.

Произведения В.И. Ленина выражают взгляды членов Политбюро ЦК РКП (б), на формирование социалистического права, советского правового просвещения поэтому входят в данный вид опубликованных источников. Изучение этого вида

постановление Агитпропотдела ЦК ВКП (б) // Еженедельник советской юстиции. 1927. № 16; Директивы ВКП (б) по вопросам просвещения: вопросы народного просвещения в Основных директивах съездов, конференций, совещаний Центрального комитета и Центральной контрольной комиссии ВКП (б). М.-Л., 1931; Пропаганда и агитация в решениях и документах ВКП(б). (1900-1946 гг.) / Сост. Е.Д. Ворошилова, С. М. Зорина. М., 1947 и др.

35 Ленин В.И. Войско и революция // Полн. собр. соч. Т. 12. С. 111 114; Его же. Очередные задачи Советской власти // Полн. собр. соч. T. 36. С. 168-208; Его же. Наказ по вопросам хозяйственной работы, принятый IX Всероссийским съездом Советов 28 декабря 1921 г. // Полн. собр. соч. Т. 44. С. 335-338; Его же. О задачах Наркомюста в условиях новой экономической политики (письмо Д.И. Курскому) // Полн. собр. соч. Т. 44. С. 396-400; Его же. О государстве и праве. Сб. произведений, документов в 2-х тт. М., 1958 и др. 
источников способствует формированию у исследователя представлений об условиях, характере и особенностях образовательной политики советского государства в изучаемые хронологические рамки.

Привлечение к исследованию данного вида исторических источников основано на специфике партийногосударственного управления, существовавшего в СССР. В партийных документах и работах В.И. Ленина содержится раздробленная многоуровневая информация, а, следовательно, потребовалось выявление и изучение всех взаимосвязанных материалов и их без конъюнктурная интерпретация.

Третьим видом письменных исторических источников являются публикации о дискуссиях идеолого-правового характера, которые отчасти носят и историографический характер. Пришедшие к власти в России представители РКП (б) объявили о сломе буржуазной правовой системы, действовавшей до октября 1917 г., и ее замене социалистическим правом. Однако среди представителей советского аппарата не существовало единого мнения о концепции строительства правового поля в РСФСР. Основные «баталии» разгорались на съездах и конференциях, в ходе которых делегаты высказывали различные взгляды не только на формирование советского правового поля, но и делились опытом правового просвещения $^{36}$. Анализ материалов этого вида источников

36 Протоколы III Всероссийского съезда деятелей советской юстиции, с приложениями резолюций Съезда. М., 1921; Резолюции V Всероссийского съезда Советской Юстиции 10-15 марта 1924 г. М., 1924; Второй Всероссийский съезд административных работников (23-30 апреля 1928 г.). Сокращенная стенограмма. М., 1929; Резолюция VI совещания руководящих работников юстиции по 
дополняет картину процесса становления советского правового поля и способствует пониманию трудности поиска концепции распространения правовых знаний через призму марксистско-ленинской методологии.

Четвертая группа письменных источников - материалы периодической печати, которая представляла собой «зеркало» общества, поскольку регулярно отображала актуальные события. В свою очередь данный вид источников целесообразно разделить на 2 подгруппы.

Первая подгруппа представлена газетами и журналами, освещавшими взгляы представителей разных политических сил в области правового образования ${ }^{37}$. В периодических изданиях публиковались доктринальные взгляды руководителей ведомств на формирование системы права, реорганизацию правового просвещения и др.

Вторая подгруппа - дальневосточные средства массовой информации. В советских региональных СМИ в обезличенных информационно-новостных сводках, объявлениях, обозрениях и очерках сообщалась

докладу Н.В. Крыленко «Об очередных задачах органов юстиции и содокладу т. Нюриной «О методах работы, контроле исполнения и служебной дисциплине» утвержденная коллегией НКЮ 25 февраля (II) 1932 г. // Советская юстиция. 1932. № 6-7. С. 27-34 и др.

37 Сибирский вестник. Омск. 1918; Правительственный вестник. Омск - Иркутск, 1918-1919; Народное просвещение. М., 1918-1921; Правда. М., 1918-1941; Беднота. М., 1920 и др.;

Резолюция пленарного заседания Всесоюзного совещания по подготовке кадров при Институте советского строительства и права от 12 января 1930 г. // Советское государство и революция права. 1930. № 2. С. 159-161; Совещание в Прокуратуре Союза ССР с районными следователями // Социалистическая законность. 1936. № 7. С. 73-83; Всесоюзное совещание по вопросам юридического образования // Социалистическая законность. 1938. № 7. С. 99-101 и др. 
информация о советской системе просвещения, в том числе и правового. Публикации позволили реконструировать картину общественно-политической ситуации, понять трудности с которыми столкнулись дальневосточные государственные органы при реализации мероприятий советской власти в области правового просвещения.

К пятой группе письменных источников относятся источники личного происхождения. Воспоминания участников событий рассматриваемого в исследовании периода касающиеся правового просвещения на Дальнем Востоке России малочисленны ${ }^{38}$. Однако сохранившиеся материалы позволили дополнить картину событий истории Гражданской войны в общем контексте противостояния идеологий.

Основной компонент источниковой базы исследования - архивные документы. Важное значение для изучения истории правового просвещения на Дальнем Востоке России и в Маньчжурии в 1917-1941 гг. имеют документы хранящимся в фондах центральных и региональных архивов: Государственного архива Российской Федерации (далее - ГАРФ), Российского государственного архива социально-политической истории (далее - РГАСПИ), Российского государственного исторического архива Дальнего Востока (далее - РГИА ДВ), Государственного архива Забайкальского края (далее - ГАЗК), Государственного архива Приморского края (далее -

38 Шапиро М.Л. Харбин, 1945 // Память: исторический сборник. Нью-Йорк, 1978. С. 3-92; Семенов Г.М. О себе. Воспоминания, мысли, выводы. 1904-1921. М., 2007; Гинс Г.К. Сибирь, союзники и Колчак. Поворотный момент русской истории. 1918-1920. М., 2008. 
ГАПК), Государственного архива Хабаровского края (далее - ГАХК), Государственного архива Амурской области (далее - ГААО). Автором была использована информация, содержащаяся в 74 фондах 7 федеральных и региональных архивов.

Массив архивных источников, можно условно разделить на 3 группы:

1. Делопроизводственная документация органов власти, партийных органов и отраслевых подразделений.

2. Делопроизводственная документация образовательных учреждений и их структурных подразделений.

3. Непериодические печатные публикации.

Первую группу архивных источников составляют делопроизводственная документация органов власти, партийных органов и отраслевых подразделений. Массив делопроизводственных материалов комплектуют организационные, протокольно-распорядительные и отчетные документы, материалы деловой переписки и документы личного характера.

Наиболее информативными о советских органах власти являются фонды Р-393 и Р-9492 ГАРФ. Материалы деятельности народного комиссариата внутренних дел РСФСР (Ф. Р-393 ГАРФ) посвящены основным направлениям работы наркомата. Сохранились уставы, положения об организации структурных подразделений, регламенты их работы, правила внутреннего распорядка и иные документы касающиеся правового просвещения сотрудников советских органов милиции. Документы, комплектующие фонд Р-9492 ГАРФ отражают усилия министерства юстиции СССР по правовому просвещению 
специалистов ведомства. Содержат постановления, приказы, директивы, инструкции об организации деятельности и другие нормативные документы.

Документы, представленные в фондах Государственного архива Российской Федерации (Ф. Р9474 - Верховный суд СССР, Ф. Р-9492 - министерство юстиции СССР), Российского государственного архива социально-политической истории (Ф. 372 - Дальневосточное бюро ЦК РКП (б)), Российского государственного исторического архива Дальнего Востока (Ф. Р-2422 Дальневосточный революционный комитет, Ф. Р-2460 Прокурор Дальневосточной области, Ф. Р-3190 Прокуратура Амурской области), Государственного архива Забайкальского края (Ф. Р-11 - Забайкальский губернский суд, Ф. Р-27 - Дальневосточный революционный комитет, Ф. P-49 - Читинский окружной суд, Ф. Р-875 - Министерство юстиции Совета министров Дальневосточной республики), а также Государственного архива Хабаровского края (Ф. П-2 Дальневосточный краевой комитет ВКП (б), Ф. Р-18 Министерства Дальневосточной республики, Ф. Р-19 Управление делами Совета министров Дальневосточной республики, Ф. П-30. - Хабаровский городской комитет Коммунистической партии РСФСР, Ф. П-35 Хабаровский краевой комитет ВКП (б), Ф. Р-137 Исполнительный комитет Хабаровского краевого совета народных депутатов, Ф. Р-819 - Хабаровский краевой суд, Ф. Р-1399 - Главное управление министерства юстиции Российской Федерации по Хабаровскому краю) являются уникальными, не дублируются и в них содержаться материалы об организации правового просвещения 
сотрудников органов советской юстиции. Такая мозаичность информации связана с несистемным характером правового просвещения специалистов дальневосточных органов советской юстиции. Поэтому в фондах центральных и региональных архивов выявлены единичные документы, позволившие сформировать картину постижения, действующего законодательства представителями суда и прокуратуры.

Деятельность дальневосточных партийных органов освещена в фондах П-2, П-30, П-35 и П-44 ГАХК, в которых представлены материалы, содержащие сведения о руководстве партии правоохранительным органам. Полученные материалы отражают деятельность пропагандистов, партийной кружковой работы, материалы партийных съездов и совещаний. Кроме того, партийные фонды располагают организационной документацией, включающей в себя положения, должностные инструкции, структуру и штатную численность, учебные планы и др. Данный вид источника представляет собой систему взаимосвязанных документов, определяющих порядок организации профессионального просвещения, задачи, функции, принципы деятельности структур и подразделений ответственных за правовое просвещение, а также права, обязанности и ответственность всех сотрудников правоохранительных органов.

Протокольно-распорядительная документация представлена решениями, распоряжениями, указаниями, приказами и протоколами, касающимися правового просвещения дальневосточников. Наибольший массив таких документов сохранен в фондах ГАРФ (Ф. Р-393, Ф. Р-9492), 
РГИА ДВ (Ф. Р-2422), ГАЗК (Ф. Р-27, Ф. Р-49, Ф. Р-875), ГАХК (Ф. П-2, Ф. Р-18, Ф. Р-19, Ф. П-30, Ф. П-35, Ф. Р-58). Bce изученные документы отражают реализацию возложенных на них функций в сфере правового просвещения специалистов правоохранительных органов и жителей Дальневосточного региона, характеризуют повседневную деятельность партийных и советских структур.

Значимым источником информации стали материалы фондов органов исполнительной власти Дальневосточного региона. Фонды Р-534 и Р-2422 РГИА ДВ, Р-27 ГАЗК, Р-58, Р137, Р-410 ГАХК сохранили приказы и протоколы заседаний, связанные с мероприятиями в сфере правового просвещения дальневосточного населения. Выявленные материалы позволили сравнить общегосударственный курс правового просвещения населения с практикой его реализации.

Информационные сводки дальневосточных государственных структур о кадровом составе советских территориальных органов милиции и юстиции, деятельности милицейских курсов и школы, проводимых с ними внешкольных занятий направляемые в Дальневосточное бюро ЦК РКП (б) сохранились в материалах 372 фонда РГАСПИ. Партийные органы контролировали организацию образовательных учреждений, проведение в них процесса обучения, классовый состав преподавателей и курсантов, распределение выпускников и их деятельность в практических подразделениях. Изучение материалов данного фонда позволило сформировать представление не только о роли партийных и государственных структур в организации правового просвещения в Дальневосточном 
регионе, но и проследить динамику партийной принадлежности сотрудников дальневосточных органов юстиции и милиции.

Сведения о деятельности милиции и органов юстиции буферной Дальневосточной республики сохранены в фондах Р-18, Р-19, Р-864 ГАХК. Изучение отчетов, поступавших в исполнительные органы важно для воссоздания полной и объективной картины условий работы правоохранительных органов в ситуации существования буфера и становления советской государственности в Дальневосточном регионе. Проанализированные архивные материалы свидетельствуют $\mathrm{O}$ классовом подходе при комплектовании правоохранительных органов, позволяют раскрыть непростой процесс становления и функционирования курсов для советских юристов. Материалы фондов содержат сведения о проведении инструктирования сотрудников милиции, зачисленных на службу впервые. Их изучение позволило сделать вывод о том, что такая форма просвещения являлась вынужденной мерой в ситуации недостатка стационарных образовательных учреждений.

В материалах фондов Р-27, Р-49, Р-875 ГАЗК освещены мероприятия по ликвидации правовой безграмотности среди работающих в ДВР сотрудников милиции и юстиции. Собранные материалы сформировали представление о практике реализации директив советского руководства в условиях существования буфера. Кроме того, имеются отчеты о проведенных в Дальневосточной области (крае) юридических курсов, отзывы на работу выпускников, 
получивших правовое образование. Почерпнутые сведения позволили собрать информацию о личном составе дальневосточных милиционеров, выяснить источники комплектования, требования к абитуриентам, программы подготовки курсантов, а также классовый состав обучающихся.

Рассматриваемый в исследовании период - это не только развитие правового просвещения, но и в обобщенном смысле - изучение развития отечественной культуры. В преобразовании общества ей отводится одно из важнейших мест. Основной целью культуры рассматриваемого периода являлось формирование советской идентичности, и наиболее массово использовались произведения искусства. Искусство как вид исторического источника включает в себя зрелищноигровое, изобразительное и декоративно-прикладное. Проведение временного среза развития культуры способствуют пониманию не только образа жизни, но и образа мышления людей, раскрывает стереотипы общественного сознания руководящие поведением людей, и, в конечном итоге способствует пониманию «духа времени».

Их основу зрелищно-игрового искусства составили документальные и игровые фильмы, выпущенные в советский кинопрокат. Кинопроизведения создавались на актуальные темы и опосредованно формировали представления о советском праве у зрителей.

Наиболее информативным источником в исследовании стали произведения изобразительного искусства. Политический плакат, как вид изобразительного искусства стал в России массовым средством политической агитации и пропаганды. Использование простых, но емких и ярких графических образов, лозунгов положительно влияло 
на сообщение важной информации населению страны. Источниками для рассмотрения темы правового образования и просвещения на Дальнем Востоке России в 1917-1941 гг. стали плакаты, посвященные кооперации, борьбе с неграмотностью, политике советской власти в сфере индустриализации и коллективизации крестьянских хозяйств, а также связанные с процессом выборов советских органов власти.

Интересным историческим источником по правовой пропаганде и агитации стали изделия декоративноприкладного искусства. Фарфорофаянсовые изделия являясь частью ленинского плана монументальной пропаганды включали в себя предметы с советскими лозунгами и эмблемами. Традиционные народные промыслы, прежде всего палехская миниатюра, также использовали агитационные сюжеты. Их распространение привлекало внимание населения, способствовало распространению положительных эмоций об успехах советского государственного строительства. Огромное распространение получили агитационные ткани. Текстиль являлся продуктом социального заказа, был доступен населению.

Данная группа исторических источников отчасти носит субъективный характер, отвечает политическому заказу, но вместе с тем, ретранслирует историческую атмосферу изучаемого периода, фиксирует облик людей и передает общее правосознание населения.

Таким образом, история существования правового просвещения на Дальнем Востоке России в 1917-1941 гг. представлена значительным кругом источников. Комплексный и критический анализ всей совокупности 
исторических источников, имеющих разноплановый характер и содержание, и по нашему мнению дает возможность реализовать поставленную цель и задачи заявленной темы исследования. Привлечение источников разного вида позволяет сопоставлять материал и объективно изучать процессы становления и развития отечественного правового просвещения на протяжении всего хронологического периода темы исследования. Таким образом, привлеченный автором источниковый материал, несмотря на определенную неполноту обобщающих сведений, имеет разноплановый характер и содержание и является основой для решения поставленных в диссертации задач. Способствует проведению анализа основных направлений правового образования и просвещения в Дальневосточном регионе в 1917-1941 гг., а также выявлению и изучению практики реализации государственной правовой политики на региональном уровне.

Научная новизна монографии во многом определяется целостным подходом к проблеме и новизной источниковой базы. Цель монографии состоит в том, чтобы на основе системного подхода к изучению и анализу научной литературы, архивных документов и опубликованных источников обобщить исторический опыт правового просвещения на Дальнем Востоке России в 1917-1941 гг. При этом ряд аспектов темы требуют специального изучения. В монографии рассматриваются теоретические подходы к изучению правового просвещения; исследуются этапы становления советской системы правового просвещения; анализируются 
особенности правового просвещения в системе профессиональной подготовки сотрудников дальневосточных государственных органов; изучается процесс формирования правовой культуры сотрудников органов милиции Дальнего Востока.

Практическая значимость работы обусловлена введением в научный оборот массива документов и материалов, способствующих разработке и внедрению новых, ранее не использованных подходов к обучению и воспитанию специалистов в области юриспруденции. 


\section{ГЛАВА 1. ПРАВОВОЕ ПРОСВЕЩЕНИЕ: ТЕОРЕТИЧЕСКИЙ АСПЕКТ}

Общественное развитие тесно связано с распространением знаний среди населения страны и уровнем профессиональной компетентности граждан. Государства, создавая свою образовательную модель определяют требования к образованному человеку. Поэтому каждый исторический этап характеризуется своим пониманием терминов, обозначающих распространение знаний и обучение.

Впервые о воспитании в контексте образования и просвещения заговорили мыслители эпохи Просвещения, понимая воспитание как природосообразность развития человека. Просвещение же понималось как культурное развитие, философская категория и политическая идеология. Россия, вступив в ХX в. оказалась в гуще экономических, политических и правовых трансформаций, неизбежным спутником которых стал кризис правосознания населения. Революционный слом существовавшей модели государства, поиск новой схемы государственного строительства стал одной из причин правового нигилизма населения нашей страны.

Социальные преобразования, захлестнувшие Россию после октябрьских событий 1917 г., обострили необходимость налаживания эффективной коммуникационной связи с населением огромной страны. Еще в начале XX в. правовед и социолог Л.И. Петражицкий обосновал особое культурновоспитательное, педагогическое воздействие права на социум, доказал, что развитие государства требует понимания населением основных составляющих его политики. Он считал, что в период становления государственных 
институтов распространение знаний об их деятельности играет важную роль, т.к. обеспечивает не только электоральную поддержку, но и способствует быстрому принятию гражданами изменений правового поля. Наиболее эффективным способом распространения знаний среди общественности, по его мнению, является просвещение.

Провозглашение в октябре 1917 г. создания пролетарского государства потребовало от его идеологов поиска социальной базы для реализации своих идей. Убежденность в правильности марксистских взглядов на структуру общества поддерживало далеко не все население России. Поэтому основной целью большевистской партии и советского правительства стало проведение работы по формированию идейности и убежденности граждан нового государства в правильности проводимой советской политики и реализуемой коммунистической идеологии. Основным способом достижения этой цели стало воспитание. В революционные годы и до конца 1920-х гг. термин «просвещение» практически не употреблялся. Воспитание представлялось советским педагогам как «сознательное, целесообразное и планомерное воздействие на волю человека», результатом которого является «создание человека определенного типа» ${ }^{39}$. В это же время А.В. Луначарский и П.П. Блонский понимали воспитание

39 Подробнее см.: Иорданский Н.Н. Основы и практика социального воспитания. М., 1923; Крупская Н.К. Педагогические сочинения в 10 томах: T. 2. Общие вопросы педагогики: Организация народного образования в СССР М., 1958; Макаренко А.С. О воспитании. М., 1985 и др. 
как стимулирование внутренних сил человека ${ }^{40}$. Один из крупных ученых разрабатывавших идеи марксистской педагогики А.П. Пинкевич под воспитанием понимал восхождение к более совершенному образу, идеалу и видел приближение к нему через «планомерное длительное воздействие одного человека (или одних людей) на другого (других) с целью развития природных, биологических или социально-полезных свойств последнего» ${ }^{41}$.

Усиление марксистских позиций во всех сферах жизни общества, в том числе и в системе советского образования произошло после XIV съезда ВКП (б) (1925 г.) принявшего курс на строительство социализма. Воспитание, как часть образовательного процесса, стало рассматриваться в качестве закрепления, расширения, углубления завоеваний, мыслей, воли пролетарской революции, ответственного за формирование чувств и поведения в «нужном направлении». Началась активная разработка и рассылка на места государственных программ преподавания дисциплин, курсов, отдельных лекций и бесед как для образовательных учреждений, так и для системы просвещения. Их основой стало марксистско-ленинское учение. Учебный материал отвечал классово-партийной направленности, знакомил учащихся и слушателей с политическим и экономическим устройством государства, стимулировал их применять полученные знания в трудовой деятельности.

40 Луначарский А.В. О воспитании и образовании М., 1976; Блонский П.П. Избранные педагогические сочинения в 2-х томах. Т. 1. М., 1979 и др.

${ }^{41}$ Пинкевич А.П. Педагогика в 2-х томах. М., 1924-1925 гг. 
В конце 1920-х гг. в отечественной педагогической науке вновь произошел пересмотр подходов. Советские педагоги стали трактовать «воспитание» как «систему получения приспособительных навыков». Один из видных педагогов-ученых сотрудник наркомата просвещения, заместитель директора научно-исследовательского института научной педагогики, автор первой советской педагогической энциклопедии А.Г. Калашников отмечал, что «воспитание, получают не в школе, а в жизни, не в детстве только, а всю жизнь. Учиться и воспитываться необходимо на собственном практическом опыте» ${ }^{42}$. Такой подход оказал существенное влияние на всю систему советского просвещения.

Употребления, а, следовательно, и трактования терминов «правовое просвещение» и «правовое образование» в 1920 1930-е гг. не существовало. Их воспринимали как проявление коммунистического воспитания. Его основой являлись сочинения К. Маркса и В.И. Ленина о сознании и социальной природе воспитания, его классовом характере и т.д. А конечной целью выступали искоренение правонарушений, замена уголовного наказания мерами общественного порицания. Содержание правового воспитания характеризовалось «классово-пролетарским характером, производственно-краеведческим знанием предмета, общественно-полезной ценностью того труда, в процессе которого приобретаются трудовые знания и умения, воспитанием коллективистских навыков, такой организации внешней среды, которая вырабатывала бы

42 Педагогическая энциклопедия / Под ред. А.Г. Калашникова. Т. 1. М., 1929. Ст. 474, 502. 
навыки разумно дисциплинированного поведения и творчески активного и исследовательского отношения к окружающему» $^{43}$. Задачи целенаправленного правового информирования населения не ставились.

В настоящее время, соглашаясь с некоторыми подходами Л.И. Петражицкого и воспитательной практикой 1920-1930-х гг., теория юриспруденции среди прочих функций права выделяет и воспитательную, обращенную на формирование правового сознания и правовой культуры граждан, т.е. активно способствующую повышению авторитета права и закона, сближению права и морали ${ }^{44}$. Современное отечественное законодательство употребляет термин «просвещение» закрепленный в «Модельном законе о просветительской деятельности». Понимая под просвещением - не стандартизированный процесс распространения достижений науки и культуры, иных социально значимых сведений среди представителей широких слоев населения ${ }^{45}$. В настоящее время подходы к пониманию просвещения многозначны. Можно выделить два направления понимания этого термина. Первое отражено в «Педагогическом словаре» авторов Г.М. и А.Ю. Коджаспировых, в котором просвещение понимается

43 Педагогическая энциклопедия / Под ред. А.Г. Калашникова. Т. 1. М., 1929. Ст. 501, 509-510.

44 Певцова Е.А., Каменский Я.С. О понимании воспитательной функции права в отечественной и зарубежной юриспруденции // Фундаментальные и прикладные исследования кооперативного сектора экономики. 2014. № 1. С. 151.

45 Модельный закон о просветительской деятельности: принят 20 мая 2016 г. на сорок четвертом пленарном заседании Межпарламентской Ассамблеи государств - участников СНГ // https://narodirossii.ru/ [дата обращения 4 мая 2019 г.] 
как разновидность образовательной деятельности, задачей которой является широкое распространение знаний и достижений культуры, отвечающей запросам времени и способствующей пониманию жизни в целом и отдельных ее сторон. Авторы в просвещении видят и пропаганду различных идей, их внедрение в сознание людей в целях привлечения к участию в деятельности. Методами просвещения исследователи считают лекции, проповеди, беседы и т.п. В данном подходе в понятие «просвещение» заложены некоторые аспекты обучения.

Второе направление понимания термина «просвещение» связано с его воспитательным характером. Оно представлено исследованиями Е.А. Певцовой и М.В. Снигиревой сделавших вывод, что просвещение - это часть воспитательного процесса, которая содержит в себе распространение моральных ценностей и правовых принципов через различные виды идейно-политической и культурно-просветительной деятельности ${ }^{46}$. В теории юриспруденции в русле этого направления близким к пониманию «просвещения» является термин «правовое воспитание». Известный правовед Н.И. Матузов понимает

46 Певцова Е.А. Современные подходы юристов к вопросу соотношения дефиниций «правовая культура», «правовое воспитание», «правовое образование» // Основы государства и права. 2001. № 6. С. 61-69; Ее же. Правовое воспитание и формирование правового сознания в России: история и современность // Журнал российского права. 2003. № 9. С 39-44; Ее же. Правовое воспитание: вопросы теории и практики. М., 2013; Ее же. Правовое просвещение в России: состояние, проблемы и перспективы развития. М., 2019; Снигирева М.В. Общественные ресурсы в педагогических технологиях правового просвещения. Автореф. дис. ... кандидата пед. наук. Екатеринбург, 2009. С. 14; 
правовое воспитание как целенаправленную деятельность государства и общественных структур, средств массовой информации и трудовых коллективов по формированию правового сознания и правовой культуры граждан ${ }^{47}$. Формами правового воспитания ученый считает проведение лекций и бесед, консультирование, издание брошюр, а также выступления на радио и телевидении, публикации в печатных изданиях.

В аналогичном русле правовое просвещение трактуют юристы-практики ${ }^{48}$. Так, Председатель Верховного суда Российской Федерации В.И. Лебедев под правовым просвещением понимает распространение знаний о праве и разъяснение действующих положений нормативных правовых актов, а также практического их применения. По его мнению правовое просвещение включает в себя правовое обучение, т.е. преподавание правовых знаний в образовательных учреждениях, правовую пропаганду распространение в доступной форме сведений о правовых актах, а также правовое консультирование как разъяснение юридических норм ${ }^{49}$. Подобная трактовка термина «правовое просвещение» дана и в Рекомендациях

${ }^{47}$ Матузов Н.И. Теория государства и права. М., 2003. С. 248.

48 О бесплатной юридической помощи в Российской Федерации: федер. закон № 324-Ф3 от 21 ноября 2011 г. // Российская газета. 2011. 23 нояб.; Об основах системы профилактики правонарушений в Российской Федерации: федер. закон № 182-ФЗ от 23 июня 2016 г. // Российская газета. 2016. 28 июня.

49 Лебедев В.М. Выступление Председателя Верховного суда Российской Федерации В.М. Лебедева // Российский судья. 2009. № 1. С. 10. 
Генеральной прокуратуры низовым структурным подразделениям надзорного органа ${ }^{50}$.

В своем исследовании мы будем рассматривать правовое просвещение включая в него правовое воспитание и изучение правовой практики.

Сообщение профессиональных знаний осуществлялось через «внешкольное образование». Этот термин существенно изменил свою трактовку за прошедшее столетие. В первые годы советской власти под ним понималось просвещение и воспитание взрослого населения $^{51}$. Как отмечал народный комиссар по просвещению А.В. Луначарский «Внешкольное образование есть вся жизнь!» ${ }^{52}$. Он полагал, что «школа для взрослых должна занять широкое место в общем плане народного обучения» ${ }^{53}$. В настоящее время термин «внешкольное образование» заменен на «дополнительное образование» ${ }^{54}$. Под ним понимается вид образования,

${ }^{50}$ Об организации в органах прокуратуры Российской Федерации работы правовому просвещению и правовому информированию: приказ Генерального прокурора Российской Федерации от 2 августа 2018 г. // Генеральная прокуратура Российской Федерации. Режим доступа: www. https://genproc.gov.ru [19 марта 2019 г.]

${ }^{51}$ Звягинщев Е.А. Словарь внешкольнаго образованія. М., 1918. С. 18-19.

52Луначарский А.В. О воспитании и образовании. М., 1976. С. 361.

${ }^{53}$ Обращение народного комиссара по просвещению. 29 октября 1917 г. // Народное образование в СССР. Общеобразовательная школа. Сб. док. 1917 - 1974 гг. / Сост. А.А. Абакумов. М., 1974. С. 7-9.

54 Ройтблат О.В. Экскурс «от внешкольного образования взрослых» к неформальному образованию взрослых в современный период // Социальные отношения. 2012. № 1 (4). С. 5-10; Мухина Т.Г. История и перспективы развития дополнительного профессионального образования в России // Приволжский научный журнал. 2013. № 3 (27). С. 123-128; Шарапова Э.А. От внешкольного к дополнительному образованию: историко-педагогический аспект // 
направленный на всестороннее удовлетворение образовательных потребностей человека в интеллектуальном, духовно-нравственном, физическом и (или) профессиональном совершенствовании и не сопровождается повышением уровня образования ${ }^{55}$. Поэтому автор исследования употребляет термин «внешкольное образование» в контексте 1920-1930-х гг. и понимает под ним профессиональное просвещение сотрудников занимающихся правовой деятельностью в соответствии с занимаемой должностью. Такое профессиональное просвещение не проводилось в образовательных учреждениях, но имело определенный план и программу.

Таким образом, в 1917-1941 гг. шел процесс формирования теоретических подходов к изучению проблемы правового просвещения. Некоторые концепты получили дальнейшее развитие и нашли свое место в современных концепциях понимания правового просвещения.

Профессиональный проект: идеи, технологии, результаты. 2015. № 1 (8). С. 97-101 и др.

55 См.: Об образовании в Российской Федерации: федеральный закон № 273-Ф3 от 29 дек. 2012 г. (в ред. от 19 февр. 2018 г.) // Собрание законодательства Российской Федерации. № 53 (ч. I), 31 дек.2012, ст.7598. 


\section{ГЛАВА 2. ЭТАПЫ СТАНОВЛЕНИЯ СОВЕТСКОЙ СИСТЕМЫ ПРАВОВОГО ПРОСВЕЩЕНИЯ}

Учитывая сложность и противоречивость создания правового поля советской России, формирование и становление в нем правового просвещения прошло несколько этапов.

Приход к власти в России партии большевиков в октябре 1917 г. ознаменовал начало первого этапа формирования системы правового просвещения. Он был связан с процессом становления советской власти в условиях гражданского противостояния, вооруженной интервенции, непринятия частью населения мероприятий в налоговой сфере. $\mathrm{B}$ этот период одной из первоочередных задач советской власти стала ликвидация «буржуазной» системы правового просвещения и формирование новых образовательных форм, соответствующих принципам и идеологии «пролетарского» государства.

Советские учёные ожидали скорого «выветривания» права, рассматривая его как устаревшую категорию, подлежащую замене техническими нормами регулирования. На протяжении 1920-х гг. в научных кругах продолжалась полемика о становлении методологии советского права. Преподаватели-юристы, имевшие досоветскую подготовку, негативно воспринимали происходившие в советской России перемены, зачастую переходя в открытую оппозицию пришедшим к власти большевикам. Педагоги рассуждали о легитимности власти, отрицательных последствиях ломки 
законодательства Российской империи, о перспективах высшего образования в неграмотной стране.

Распространение идей о скором неизбежном отмирании права приводило к массовому правовому нигилизму. Дуализм мнений, высказанный в тезисах об отмирании государства и права с одной стороны, и объективная необходимость в законе, стали немаловажным фактором в формировании «революционного правосознания» ${ }^{56}$. Этот концепт, несмотря на всю его противоречивость, на долгие годы станет основой советского правопонимания и судопроизводства.

Разъяснение идей коммунистической партии России являлось одной из приоритетных задач просвещения. О необходимости развертывания политической пропаганды и культурно-просветительской работы среди населения говорилось в Декрете СНК РСФСР «О мобилизации грамотных и организации пропаганды Советского строя» принятом в октябре 1918 г. ${ }^{57}$. Весной 1919 г. на VIII съезде

56 «Революционное правосознание» как источник права было закреплено в п. 5 Декрета СНК РСФСР от 22 ноября 1917 г. «О суде».

Советская правовая система берет свое начало на II Всероссийском съезде Советов на котором были приняты первые декреты Советской власти, а в дальнейшем дополнена нормативными правовыми актами, изданными различными советскими структурами. Тем не менее правотворчество в первые месяцы носило фрагментарный характер, поэтому закрепление «революционного правосознания» в качестве источника права должно было заполнить пробелы правового регулирования.

Основой принятия управленческих решений сформированного в 1917-1941 гг. партийного и государственного аппарата являлись работы лидеров коммунистической партии и решения партийных органов, а с середины 1920-х гг. формой (источником) советского права стали конституция, законы и подзаконные акты, заменившие «революционное правосознание».

${ }^{57}$ Собрание узаконений и распоряжений правительства за 1917 1918 гг. Управление делами Совнаркома СССР М., 1942. С. 1324-1325. 
РКП (б) в докладах также отмечалась необходимость пропаганды коммунистических идей, широкое разъяснение общественности декретов Советской власти. Правовая пропаганда как средство привлечения внимания населения к проводимой политике активно велась через партийные и внепартийные газеты, в которых публиковались официальные документы и разъяснения должностных лиц по правовым вопросам с которыми наиболее часто сталкивалось население страны. Практическая реализация пропаганды виделась, среди прочих направлений, через разъяснение Советской Конституции, а для неграмотного населения - чтение Декретов советской власти и обязательных постановлений $^{58}$. VIII Всероссийская конференция РКП (б) подтвердила решения Съезда и приняла тезис о необходимости мобилизации грамотных коммунистов для чтения газет и брошюр в лазаретах, клубах, избахчитальнях и т.п. ${ }^{59}$. Однако массовая безграмотность населения существенно тормозила этот процесс. Руководитель советского государства В.И. Ленин отмечал, что «пока у нас в стране есть такое явление как безграмотность, о политическом просвещении трудно говорить» ${ }^{60}$. Поэтому ликвидация неграмотности, в том числе и коммунистической была объявлена неотложной задачей государства.

Огромное количество неграмотного населения привело к тому, что основным средством агитации и пропаганды

58 Директивы ВКП (б) по вопросам просвещения М. - Л., 1931. С. $24-25$.

59 Пропаганда и агитация в решениях и документах ВКП (б) М., 1947. С. 96.

${ }^{60}$ Ленин В.И. Полн. собр. соч. Т. 44. С. 174. 
стал плакат. Художественно иллюстрированное крупноформатное печатное тиражное издание не содержало прямых ссылок на декреты и директивы советской власти, но позволяло малограмотному гражданину уяснить ее требования. Например, декрет о сдаче оружия опубликованный 10 декабря 1918 г. был проиллюстрирован художником А.П. Апситисом нарисовавшим плакат «Граждане, сдавайте оружие», постановление ВЦИК «О принудительном наборе в РККА» отражено плакатами «Запись в Красную Армию» и «Год Красной Армии 1918-1919», а декрет о ликвидации безграмотности в плакатах «Знание разорвет цепи рабства» и «Неграмотный - тот же слепой, всюду его ждут неудачи и несчастья!». О выпусках плакатов сообщалось в газете «Правда», их доставка приравнивалась к срочным военным грузам, а уничтожение и заклеивание рассматривалось как преступление.

Подготовка кадров для агитационно-пропагандистской работы началась еще летом 1918 г., когда в Москве открылись курсы агитаторов и инструкторов при ВЦИК, весной 1919 г. переименованные в Центральную школу советской и партийной работы. Учебный план образовательного учреждения предполагал одновременное 3-месячное обучение 500 чел., старше 18 лет по общетеоретическому и политико-юридическому циклам. Слушатели ежедневно изучали содержание советской, кооперативной и профсоюзной работы, знакомились со структурой центрального и местного управления в РСФСР, основными направлениями работы органов 
юстиции,

правоохранительной системы ${ }^{61}$.

Агитационно-пропагандистская работа под руководством ЦК РКП (б) начала централизованно развертываться с марта 1920 г., когда был сформирован агитационнопропагандистский отдел ЦК РКП (б), а на местном уровне организовывались аналогичные структуры. В ноябре 1920 г. к этой работе подключился Главный политикопросветительный комитет Народного комиссариата просвещения РСФСР (Главполитпросвет) и его территориальные отделения в ведении которых находились избы-читальни, клубы, библиотеки и проч. Кроме того, агитационно-пропагандистской работой занимались и общественные органы: культурно-просветительные общества, профессиональные союзы и РКСМ.

В рассматриваемый этап правовое просвещение не приобрело массового характера в связи с неграмотностью населения Советской России, разветвленностью системы органов и учреждений политической пропаганды и агитации, отсутствием четких директив Центра о содержании проводимых мероприятий и несогласованности действий между ведомствами, ответственными за агитационно-пропагандистскую работу, а также нехваткой квалифицированных специалистов способных толковать советское право и изза недостаточного количества литературы по советскому законодательству.

Не менее сложный путь реформирования прошло ведомственное правовое просвещение в структуре которого

${ }^{61}$ ГАРФ. Ф. Р-393. Оп. 12. Д. 35. Л. 232-236. 
тоже преподавались юридические дисциплины. С приходом представителей РКП(б) к власти формирование новых исполнительных органов осуществлялось на основе классовых принципов. Для охраны общественного порядка была организована рабочая милиция, деятельность которой строилась на основе тезисов, сделанных В.И. Лениным ${ }^{62}$, инструкциях Народного комиссариата внутренних дел (НКВД) РСФСР и Народного комиссариата юстиции (НКЮ) РСФСР ${ }^{63}$. В документах регламентировались требования к занятию должностей сотрудников милиции. Специальное образование не являлось обязательным условием для замещения вакансии. Основными критериями приема на службу являлись не образовательный уровень и служебный опыт, а партийная принадлежность и следование «идеалам революции». Уровень образования милиционеров был низким. К началу 1920-х гг. даже в главном аппарате милиции работали «4,2\% лиц с высшим образованием, 50\% - со средним, а остальные были малограмотными» 64.

Недостаточный уровень профессиональной компетенции с успехом замещался правовой осведомленностью. Правовое просвещение широко распространилось в среде сотрудников правоохранительных органов. Мизерное государственное финансирование заставило перевести образовательные

62 Ленин В.И. Полн. собр. соч. Т. 9. С. 203; Т. 11. С. 18-19; Т. 36. С. 195.

63 Инструкция об организации советской рабоче-крестьянской милиции // СУ РСФСР. 1918. № 75, ст. 813.

64 Шабельникова Н.А., Бакшутов С.Н. Формирование системы профессионального обучения кадров милиции на Дальнем Востоке России в 1920-е гг. // Теория и практика общественного развития. 2015. № 21. С. 182. 
учреждения на местный бюджет, что негативно сказалось на их сети. И, в ситуации недостаточности образовательного уровня низовых специалистов, привело к необходимости развития системы внешкольной подготовки ${ }^{65}$ которой занимался политикопросветительный аппарат милиции ${ }^{66}$. С конца апреля 1921 г. при Главном управлении милиции РСФСР действовал политический секретариат. Его подразделения в губерниях и автономных республиках были обязаны инспектировать и инструктировать подразделения милиции по вопросам партийно-политической и политикопросветительной работы. Одновременно вводился институт комиссаров и политических руководителей (политруков), которые контролировали работу командного и хозяйственно-административного состава милиции.

Сотрудники органов внутренних дел без отрыва от службы были обязаны повышать свою квалификацию через действовавшие кружки, посещение обязательных вечерних занятий, инструктирование и служебную подготовку. Все неграмотные и малограмотные милиционеры были привлечены к всеобщему обучению. Однако массового распространения внешкольная подготовка еще приобрела.

Изучение опыта становления советского правового просвещения свидетельствует, что на первом этапе руководству страны не удалось выработать единые подходы к правовому просвещению населения.

65 Об организации дела внешкольного образования: Постановление Наркомпроса РСФСР от 4 июня 1919 г. // СУ РСФСР. 1919. № 21, ст. 267. ${ }^{66}$ ГАРФ. Ф. Р-393. Оп. 23а. Д. 450. Л. 80. 
Правовое просвещение сотрудников органов советской юстиции не сложилось в связи с нехваткой литературы и квалифицированных специалистов. Распространение в органах милиции опыта правового просвещения способствовало повышению качества знаний сотрудников органов советской милиции о действующем законодательстве. Оно являлось наиболее оптимальным способом получения знаний о праве в условиях недостаточного распространения школьно-курсовой системы, удаленности территорий от центра страны и слабого финансирования обучения сотрудников правоохранительных органов.

Второй этап наполнен пересмотром подходов к пониманию правового просвещения. Он начался с развертыванием в СССР новой экономической политики. Ее реализация способствовала возрождению рыночного обмена и кооперации, развитию банковской сети, росту количества финансовых учреждений и нотариальных контор. Увеличение внутригосударственных финансовоэкономических сделок провоцировало с одной стороны расширение следственного аппарата и судебных структур, a с другой - обнажало несовершенство законодательной базы, остро нуждавшейся в коренной переработке действовавших нормативных правовых актов. Освобождение от устаревших правовых норм выразилось в проведении в первой половине 1920 -х гг. кодификации законодательства. Реформирование советской системы права способствовало повышению роли советских юристов, росту престижа юридического образования и 
сокращению потребности в специалистах получивших знания в области права до революции 1917 г.

В рассматриваемый этап правовое просвещение основывалось на правовой идеологии. Ее базой являлись принципы государственной целесообразности и преобладания интересов коллектива над личными. Важнейшей функцией права становилось строгое и неукоснительное соблюдение законов всеми субъектами права. Совокупность этих постулатов формировала советское понимание законности. В первые постреволюционные годы нормативная правовая база Советской России находилась в стадии формирования. Поэтому основным регулятором общественных отношений выступала революционная законность ${ }^{67}$. О необходимости ее укрепления в РСФСР было впервые заявлено в конце 1921 г. на IX Всероссийском съезде Советов. Переход страны к новой экономической политике потребовал не только расширения нормативной правовой базы, но и ее соблюдения всеми субъектами права. В этом смысле доктрина законности противопоставлялась «революционному правотворчеству» и «революционному правосознанию». А реорганизация чрезвычайных правоохранительных органов и переход их полномочий к Народному комиссариату юстиции должны были способствовать соблюдению законности. Теоретической основой понимания законности можно считать письмо В.И. Ленина в Политбюро ЦК РКП (б) «О «двойном» подчинении и законности» ${ }^{68}$, в котором говорилось об общеобязательности советских законов, единстве их действия на всей территории

\footnotetext{
${ }^{67}$ Емельянов И. Что такое революционная законность и зачем она нужна. М.-Л., 1926. С. 12.

${ }^{68}$ Ленин В.И. Полн. собр. соч. Т. 45. С. 197-201.
} 
РСФСР, недопустимости подмены законности целесообразностью, а также о правовой культуре населения. Исходя из этого советская правовая пропаганда должна была быть не только ориентированной на практику, но и формировать мировоззрение, основой которого выступала коммунистическая идеология. Повышение роли норм права в регулировании общественных отношений потребовало реорганизации агитационно-пропагандистской работы в РСФСР. Еще в марте 1920 г. был организован агитационнопропагандистский отдел ЦК РКП (б) которому подчинялись соответствующие структуры на местах. Помимо партийного органа политико-просветительной работой стал заниматься Главный Политико-Просветительный комитет Народного комиссариата просвещения РСФСР (Главполитпросвет) в задачи которого входили: политическая, просветительская и агитационная работа, организация сети просветительских учреждений, проведение массовых агитационных мероприятий. Однако в 1921 - 1924 гг. произошло постепенное сращивание этих структур под эгидой партии, а затем их разделение, сопровождавшиеся финансовой нестабильностью. Такие перипетии негативно сказывались на реализации агитационно-пропагандистской работы на местах, деятельность клубов и кружков сократилась, а агитационная и пропагандистская работа сосредоточилась в партийных структурах. Например, в 1922 г. Центральная Агитпропкомиссия ЦК РКП (б) указала своим починенным структурам «усилить работу по финансово-налоговой кампании выпустив 3 плаката, направить в читальни тематику 
и содержание бесед и лекций, открыть агитационные пункты в соответствии с разработанным положением» ${ }^{69}$.

Одно из ключевых значений постепенно стала занимать советская периодика. На страницах юридических журналов «Еженедельник советской юстиции», «Советское право» и других обсуждались вопросы реформирования системы юридического образования. Бюллетень центрального управления печати, пропаганды и просвещения ежедневно публиковал статьи, освещавшие успехи советского строительства, в том числе и в сфере права $^{70}$. Издание обновленных учебников и учебных пособий, расширение спектра периодической печати позволило в 1924 г. в директивном порядке отказаться от дореволюционной юридической литературы. Принятые меры способствовали популяризации знаний об особенностях советского законодательства, однако широкого распространения печатные издания не имели изза ограниченности тиража. Например, издательство «Красная новь» в 1922 г. выпустило работу В.М. Мешковского «Страхование в РСФСР» тиражом 7000 экземпляров и монографию О. Поповой «Общегражданский налог» тиражом 10000 экземпляров, что не отвечало потребностям огромной страны ${ }^{71}$. Действующие сотрудники органов советской юстиции в силу своей профессиональной загруженности, низкого уровня образования и удаленности от центральных регионов страны их практически не читали.

${ }^{69}$ ГАРФ. Ф. Р-393. Оп. 23а. Д. 244. Л. 6.

70 Там же. Оп. 3. Д. 96. Л. 1-137.

${ }^{71}$ Там же. Оп. 23а. Д. 244. Л. 30. 
Успехи издательской деятельности нивелировались сохранявшимся большим числом неграмотных и малограмотных граждан. Наиболее распространенными формами правового просвещения оставались коллективные читки, разъяснение и обсуждение газет, журналов и плакатов. Активно использовалась радиосвязь. Через радиоточки в регионы поставлялась актуальная для советской власти информация, предназначенная для широкого круга радиослушателей.

В рассматриваемый этап активизировалась деятельность по правовому просвещению милиционеров. В июне 1923 г. приказом Главмилиции была утверждена и разослана на места единая программа внешкольных занятий с рядовыми милиционерами и командующим составом милиции. Она предполагала годичный курс обучения и была направлена на ликвидацию правовой безграмотности, ознакомление сотрудников милиции с законодательством и основами оперативно-служебной работы ${ }^{72}$. При проведении массовых кампаний программа дополнялась специально разработанными лекциями. Например, в связи с развернувшейся налоговой кампанией в январе 1923 г. по требованию Главполитпросвета были включены лекции: «Налоги в связи с нэп. Краткий обзор налогового законодательства с мая 1921 г.» и «Виды налогов в РСФСР ${ }^{73}$. Стоит подчеркнуть, что разработка этих лекций и их внедрение в образовательный процесс сталкивалось с

72 Филиппова Л.Е. Формирование образовательных учреждений НКВД в период становления Советской России как часть общей кадровой политики правоохранительных органов // Вестник Владимирского юридического института. 2007. № 1 (2). С. 106.

${ }^{73}$ ГАРФ. Ф. Р-393. Оп. 23а. Д. 377. Л. 3-4. 
некоторыми сложностями, так, НКЮ отказался принимать участие в содержательном наполнении лекций, поэтому зачастую эту работу проводили сотрудники отделений политических секретариатов ${ }^{74}$.

Губернские (областные) подразделения политических секретариатов занимались обучением партийных милиционеров. В соответствие с регламентирующими документами обучение проводилось в течение 7 недель. Слушатели изучали политическую экономию, исторический материализм, историю РКП (б), политикопросветительную работу, а также по 6 часов Конституцию РСФСР и основы советского права. Курс советского права знакомил с основами Уголовного, Гражданского и Земельного кодексов ${ }^{75}$.

Перевод милицейских органов на местный бюджет негативно сказался и на политико-просветительной работе. В докладах милицейских начальников в головное подразделение отмечались «мизерность и нерегулярность денежного довольствия, недостаточная удовлетворенность натуральным довольствием» и констатировалось, что «в этих условиях политико-просветительная работа почти не ведется» ${ }^{76}$.

С 1928 г. внешкольная подготовка милиционеров вновь стала обязательной для всех категорий личного состава и называлась «повторно-инструкторские занятия». Однако, делегаты Второго Всероссийского съезда административных работников, проходившего в Москве в апреле 1928 г. отмечали, что отсутствие преподавательских кадров,

${ }^{74}$ ГАРФ. Ф. Р-393. Оп. 23а. Д. 250. Л. 17, 72-73.

${ }^{75}$ Там же. Д. 248. Л. 16-17; Д. 380. Л. 46-47.

76 Там же. Д. 377. Л. 47. 
программ обучения, а главное - времени, делают невозможным проведение с действующими сотрудниками внешкольных занятий на местах ${ }^{77}$. Но и расширение контингента милицейских школ было не возможным ввиду ограниченности финансирования, недостаточности материальной базы. В связи с этим внутренними правовыми актами НКВД было положено начало нормативной регламентации заочного милицейского образования, была введена форма обучения - экстернат. Анализируя материалы о применении экстерната как формы образования стоит подчеркнуть, что он не был широко использован, т.к. специальная юридическая литература в отдаленных регионах почти отсутствовала.

Активную роль в правовом просвещении играли средства массовой информации. В ведомственных печатных изданиях публиковались учебные планы действующих школ и курсов, что вызывало оживленную дискуссию среди специалистов. Например, опубликование учебного плана Высших юридических курсов подверглось критике читателей. На страницах журнала обсуждалось отсутствие «предмета, касающегося изучения преступности», основ судебной медицины, уголовной психологии и психопатологии, которые являлись новаторскими. Высказывались мнения о сокращении часов по уголовному праву и судопроизводству, т.к. обучающиеся имели 2-летний юридический стаж ${ }^{78}$. Вместе с тем подчеркнем, что широкого распространения печатные

${ }^{77}$ Второй Всероссийский съезд административных работников (2330 апреля 1928 г.). М., 1929. С. 57.

${ }^{78}$ Еженедельник советской юстиции. 1923. № 14. С. 187. 
издания не имели. Сказывался небольшой тираж, финансовые затруднения, да и общая неграмотность населения.

Таким образом правовое просвещение все более приобретало организационно оформленный характер. Появлялись краткосрочные нерегулярно действовавшие юридические курсы для ускоренной подготовки специалистов, обладающих правовыми знаниями. Средства массовой информации стали уделять большее внимание правовому просвещению, откликались на обсуждаемые читателями публикации, но ограниченность их тиража не позволяла широко использовать их в просвещенческой работе.

Третий этап реформирования правового просвещения начался с глобальных внутренних процессов, происходивших внутри СССР. Во второй половине 1920-х гг. в СССР четко обозначилась идеологическая диктатура ВКП (б), развернулась внутрипартийная борьба, положено начало формированию культа личности вождя, завершалось огосударствление экономики, распространялись команднорепрессивные методы управления, широкое применение получали методы государственного принуждения и внесудебных расправ. Ускоренное формирование социалистического государства с одной стороны, и наблюдавшееся со второй половины 1920-х гг. увеличение количества крестьянских и национальных восстаний - с другой, требовало не столько квалифицированных, сколько идеологически выдержанных кадров. Провозглашение в декабре 1925 г. XIV съездом ВКП (б) курса на индустриализацию страны предопределило необходимость пересмотра модели высшей школы. Уже летом 1926 г. на пленуме ЦК ВКП (б) впервые прозвучал тезис о разработке 
пятилетнего плана подготовки кадров для народного хозяйства СССР. Ответственность за обучение кадрового состава возлагалась на отраслевые наркоматы, вводились плановые цифры набора и выпуска специалистов ${ }^{79}$. Отличительной чертой и новацией всего отечественного образования стало появление высших образовательных учреждений, находившихся в ведомственном подчинении и готовивших специалистов для советских учреждений.

Первая половина 1930-х гг. положила начало открытию курсов коммунистического хозяйства и курсовых занятий для секретарей волостных исполкомов на которых осуществлялось правовое просвещение низового советского аппарата. На курсах могли обучаться советские работники не моложе 20 лет с образованием не ниже школы I ступени. Специально для этих курсов НКВД РСФСР разработал программу, рассчитанную на 540 часов. Ядро правового просвещения составляло ознакомление курсантов с основами советского законодательства о местном самоуправлении.

Начало рассматриваемого этапа связано и с широким развитием радиовещания в СССР. Одну из ключевых ролей в этом процессе

79 Об улучшении подготовки новых специалистов: резолюция Пленума ЦК ВКП (б) (4-12 июля 1928 г.) // Коммунистическая партия Советского Союза в резолюциях и решениях съездов, конференций и пленумов ЦК (1898-1986). Т. 4. 1926-1929. М., 1984. С. 355-361; О подготовке технических кадров для народного хозяйства Союза ССР: постановление ЦИК и СНК СССР от 13 февраля 1930 г. // Собрание законов и распоряжений Рабоче-Крестьянского Правительства СССР. 1930. № 6, ст. 65; О реорганизации высших учебных заведений, техникумов и рабочих факультетов постановление ЦИК и СНК СССР от 23 июля 1930 г. // Собрание законов и 
играли агитационно-пропагандистские органы политпросвещения СССР. В 1925 г. было издано постановление ЦК РКП (б) «О радиоагитации» объявившее пропаганду и агитацию с использованием радио новейшим способом работы с населением. А в январе 1927 г. вышло постановление партии «О руководстве радиовещанием» определившее главенствующую роль партийных структур в формировании содержания распространяемой информации. Рубеж 1920-1930-х гг. проходил под знаком радиолюбительского бума, однако общий контроль за передаваемой информацией оставался в руках партийных структур.

Перипетии, связанные с изменением государственноправового положения милиции ${ }^{80}$, отразились и на системе ведомственного обучения. Система правового просвещения милиционеров была нормативно регламентирована. 8 октября 1932 г. НКВД РСФСР циркуляром «О развитии общеобразовательной работы в органах РК милиции» утвердило необходимость ликвидации малограмотности среди своих сотрудников. Расширилось количество внешкольных занятий. Утвержденный центральным руководством НКВД РСФСР план учебы предполагал обучение на курсах по 90 часов в год. Ведомственным актом устанавливалось проведение занятий «через день в свободное от службы время». Основой преподавания стали практические занятия с милиционерами ${ }^{81}$. Внешкольная

распоряжений Рабоче-Крестьянского Правительства СССР. 1930. № 38 , ст. 411.

80 О мероприятиях, вытекающих из ликвидации наркомвнудела РСФСР и наркомвнуделов автономных республик: постановление ВЦИК и СНК РСФСР от 31 дек. 1930 г. // Собрание узаконений и распоряжений Рабоче-Крестьянского правительства. 1931. № 4, ст. 38.

${ }^{81}$ ГАХК. Ф. Р-1962. Оп. 1. Д. 13. Л. 33-35. 
подготовка проводилась с 1 октября по 1 мая, не менее 2 часов в неделю. Такой режим работы был обусловлен большой занятостью милиционеров, особенно работающих в сельской местности, в период весенне-летних полевых работ. Программы внешкольной подготовки, разработанные центральным милицейским руководством, предусматривали помимо изучения правовых актов, связанных с деятельностью милиции, строевое и военное обучение ${ }^{82}$. Позднее, в соответствие с учебным планом из центра занятия должны были проводиться не менее 3 раз в неделю в свободное от службы время ${ }^{83}$. При краевых и областных административных управлениях НКВД проводилась подготовка городских и сельских административных инспекторов, агентов уголовного розыска и иных специалистов для правоохранительной системы.

В ноябре 1934 г. приказом НКВД СССР для работников рабоче-крестьянской милиции был введен «Общий технический минимум» ${ }^{84}$. Все сотрудники милиции до 1 июня 1935 г. были обязаны изучить и сдать зачет по знанию видов и особенностей наружной милицейской службы, правилам задержания и привода в отделы милиции нарушителей порядка, правил наложения взысканий на месте обнаружения нарушения и нарушителя, а также общих принципов паспортизации населения. Кроме того, весь личный состав обязывался изучить законодательство СССР и ведомственные правовые акты.

82 История советской милиции: Советская милиция в период строительства социализма. М., 1977. С. 295.

${ }^{83}$ ГАХК. Ф. Р-1962. Оп. 1. Д. 13. Л. 33.

${ }^{84}$ Там же. Ф. Р-384. Оп. 8. Д. 4. Л. 69-70. 
Таким образом, развитие советской экономики, увеличение количества нормативных-правовых актов, регулировавших общественные отношения способствовали повышению привлекательности правовых знаний среди населения страны. Потребность государственных органов в специалистах разбирающихся в советском законодательстве, классовое происхождение которых отвечало духу советского государства привело к оформлению государственного заказа. Его особенность состояла в том, что СССР не нуждался в юристах «старой школы», поэтому формировал новый класс советских юристов, деятельность которых способствовала проведению преобразований советской страны. Дефицит специалистов знакомых с советским законодательством предопределил активное развитие правового просвещения.

В рассматриваемый этап правовое просвещение продолжает распространятся, хотя и уступило свои позиции юридическому образованию. Открытие курсов для сотрудников низовых советских учреждений по существу означало признание необходимости распространения правового просвещения в специфических отраслях. Подчеркнем, что правовое просвещение осталось ведущим при первичном профессиональном обучении сотрудников органов советской юстиции и милиции.

Четвертый этап развития советского правового просвещения связан с реализацией государственной аграрной политики, широкой пропагандой досрочного выполнения первого пятилетнего плана развития народного хозяйства СССР, формированием тоталитарной системы, разработкой и принятием в 1936 г. Конституции СССР, расширением полномочий репрессивных органов и 
началом борьбы с «врагами народа», а также изменением внешнеполитической ситуации и учащением вооруженных провокаций на границах страны. В сфере образования период характеризуется завершением формирования единого образовательного пространства, определением его содержательной концепции знаний, умений и представлений передаваемых обучающимся.

Правовое просвещение не утратило своей актуальности Советские юридические журналы во второй половине 1930-х гг. на своих страницах освещали вопросы подготовки юридических кадров в $\mathrm{CCCP}^{85}$, выходили в свет правила приема в высшие юридические образовательные учреждения ${ }^{86}$, издавалась учебная литература, освещались

85 Берман Я. О правовом образовании // Советское государство. 1936. № 5. С. 115-124; Бранденбургский Я. Вопросы переподготовки судебных кадров // Советская юстиция. 1936. № 8. С. 71; Долудь. Школьная и курсовая сеть юридического образования // Советская юстиция. 1938. № 5. С. 40-42; Всесоюзное совещание по вопросам юридического образования // Социалистическая законность. 1938. № 7. С. 99-101; Лопухов Р. Неотложные задачи высшего юридического заочного образования // Социалистическая законность. 1938. № 11. С. 58-59; Козлов. Заочное юридическое образование // Советская юстиция. 1940. № 1. С. 12-14; Амфитеаторв Г. Методика подготовки и чтения лекций // Советская юстиция. 1941. № 5. С. 6-8; № 6. С. 11-13; Голунский С. Учебный план и программы юридических институтов // Советская юстиция. 1941. № 1. С. 12-14; Герцензон А. Юридическое образование // Советская юстиция. 1941. № 2. С. 10-13; Гродзинский М. К методике заочного юридического образования // Социалистическая законность. 1941. № 2. С. 21-22 и др.

86 Центральные заочные курсы по правовому образованию при Московском институте советского права: положение и правила приема на заочное обучение на 1932 г. М., 1932; Инструкция по организации самостоятельной учебной работы студентов-заочников. М., 1938; Правила приема во Всесоюзную правовую академию на 1938/1939 учебный год. М., 1938; Правила приема в правовые школы. 
примеры получения рабочими и колхозниками высшего юридического образования, их продвижение по карьерной лестнице ${ }^{87}$. Постепенно печатные издания начинали играть ведущую роль в правовом просвещении.

В соответствии с руководящими документами НКВД СССР с лета 1936 г. с рядовыми милиционерами проводились еженедельные занятия. План их проведения и тематика утверждалась приказом наркомата внутренних дел СССР. Документами регламентировалось изучение юридического блока. В его рамках проводились занятия по служебным правам милиционеров, изучались виды административных взысканий, порядок составления административных протоколов, основания личного задержания и порядок проведения оперативных мероприятий. Особое внимание отводилось изучению темы «Борьба с преступностью и паспортизация». Внимание сотрудников обращалось на теоретические проблемы преступности, а также практические меры борьбы с хулиганством, беспризорными и безнадзорными детьми, расхитителями социалистической собственности.

Во второй половине 1930-х гг. в РСФСР удалось реорганизовать систему правового просвещения. В рассматриваемый этап правовое просвещение понималось не только как обучение специалистов необходимых для советской экономики, но и как выполнение определенного общественного заказа. Провозглашенная руководством страны парадигма коммунистического воспитания советского человека отодвинула знаниевый компонент образования на второй план.

M., 1938; Правила приема во Всесоюзную заочную правовую академию на 1939/1940 учебный год. М., 1939 и др.

${ }^{87}$ См. журнал «Советская юстиция» за 1938-1941 гг. 


\section{ГЛАВА З. ОРГАНИЗАЦИОННЫЕ ФОРМЫ И СОДЕРЖАНИЕ ПРАВОВОГО ПРОСВЕЩЕНИЯ НАСЕЛЕНИЯ ДАЛЬНЕГО ВОСТОКА}

Небольшевистские режимы Дальнего Востока, активно занимались правовой пропагандой. А.В. Колчак, придя к власти заявил, что главной его целью является «создание боеспособной армии, победа над большевизмом и установление законности и правопорядка» ${ }^{88}$. Ключевую роль в распространении правовых знаний играют пропагандисты, но, как отмечал Н.В. Устрялов эффективных пропагандистов не хватало. Поэтому, понимая важность доступности средств массовой информации для пропагандистской работы, он призывал адаптировать печатные формы к восприятию простым народом ${ }^{89}$.

Российские антибольшевистские газеты периода Гражданской войны включали в себя все жанры газетной публицистики. Официальные печатные издания, например, «Правительственный вестник», «Сибирский вестник», «Вестник Временного Приамурского правительства» и др. содержали огромное количество нормативной информации. Публикуемые материалы носили официальный характер и были сложны к пониманию широкого круга читателей. Площадками для пропаганды выступали проправительственные либеральные газеты и журналы, в которых в доступной

88 Гинс Г.К. Сибирь, союзники и Колчак. Поворотный момент русской истории. 1918 - 1920.М., 2008. С. 212.

89 Устрялов Н.В. 1919-й год. Из прошлого. // Русское прошлое. Историко-документальный альманах. 1993. № 4. С. 238. 
форме писалось о проводимых преобразованиях, подчеркивались идеи национализма, а в некоторых средствах массовой информации устраивались дискуссии о политико-правовом статусе государственной власти ${ }^{90}$. Значительный объем печатных полос был занят международной информацией и освещением позиций иностранных государств в связи с событиями в России. Однако большее внимание антибольшевистских СМИ уделялось борьбе с большевизмом, приводились примеры слабости, непрочности, временности большевистского влияния в российских регионах, акцентировались мероприятия советского правительства в деревне. В целом, анализируя периодическую печать небольшевистских режимов как инструмент пропаганды и агитации необходимо отметить, что пропагандистская риторика была обращена на узкий круг дальневосточного населения, вне ее поля оставалось крестьянство. А сама она не касалась правового просвещения населения.

Для пропагандистской работы использовались киноматериалы и радиостанции. Так руководство Временного Приамурского правительства для подготовки масс с целью ликвидации Дальневосточной республики использовало так называемую «Службу связи Тихого океана» состоящую из 8 крупных радиостанций. Ей удавалось не только вести трансляции на Камчатку, но и перебивать эфир из буферной республики. А киноматериалы поставляли представители американских сил. Естественно, что содержание кинолент

90 Подробнее см. : Амурская жизнь 1918-1920 гг.; Приамурский кооператор. 1919 г. и др. 
демонстрировало американский взгляд на форму правления, пропагандировало образ жизни принятый в США и способы хозяйствования.

В целом, противоречивая политика небольшевистских режимов, невозможность создания «единого фронта» борьбы с большевиками, которые тоже активно использовали доступные средства ${ }^{91}$, делали проводимую пропаганду не только неэффективной, но часто и провальной. Пропаганда идей национализма, антисемитизма, земского самоуправления и проч. не смогла противостоять единству страны, социальному равенству и патриотизму, провозглашенному большевиками.

Поставленные центральным руководством Советской России задачи по пропаганде советского законодательства реализовывались в регионах с определенными сложностями. Дальневосточная система просвещения в условиях существования буферной республики первоначально концентрировалась во Внешкольном отделе Министерства народного просвещения ДВР, которое, несмотря на свою

91 Открытое письмо к крестьянам-хлеборобам // Амурская жизнь. 1918. 30 нояб.; Культпросветработа в профсоюзах // Приморский рабочий. 1919. № 1-2; Во Владивостоке открыта Пролетарская школа // Приамурский кооператор. 1919. № 6; О созыве крестьянскоказачьего съезда // Амурская жизнь. 1920. 5, 9, 12, 15 янв.; Современная деревня // Амурская правда. 1920. 28 апр.; Положение женщины в современной России // Амурская правда. 1920. 5 июня; Внешкольное просвещение // Амурская правда. 1920. 7 июня; Коммунистическое государство // Амурская правда. 1920. 15 июня; О бесплатной юридической помощи населению города // Амурская правда. 1920. 17 июня; Финансово-экономическая политика на Дальнем Востоке // Амурская правда. 1920. 18 июня; О революции, укреплении завоеваний Октября, о социалистическом строительстве // Амурская правда. 1920. 24 июня и др. 
активную работу практически не занималось правовым просвещением населения. Ситуация с народным просвещением ухудшилась в августе 1921 г., когда недостаток финансирования, невозможность планирования деятельности в условиях гражданской войны и военной интервенции вынудили передать дело народного просвещения из Министерства в ведение местных органов власти ${ }^{92}$. Местные структуры ввиду обширного числа возложенных задач и кадрового голода не уделяли должного внимания пропаганде законодательства среди своих жителей.

Дальневосточное бюро ЦК РКП (б) ключевую роль в агитационно-пропагандистской работе среди сельского населения Дальнего Востока, отводило избам-читальням. Однако в условиях гражданского противостояния их формирование шло не так интенсивно, как в европейской части РСФСР. Целевая установка изб-читален была растиражирована в дальневосточных газетах только в мае 1920 г. $^{93}$. Документы свидетельствуют, что несмотря на распространение изб-читален в регионе, их обеспеченность газетно-журнальным фондом была недостаточной 94 ,

92 Собрание узаконений и распоряжений Правительства ДВР. 1921. № 4, ст. 93.

93 Народная библиотека-читальня // Голос учительства. 1920. 15 мая; Лыкова Е.А. Культурные преобразования в дальневосточной деревне в годы гражданской войны и военной иностранной интервенции (1918-1922 гг.) // Социально-культурное развитие СССР (советский период): сб. науч. тр. Владивосток, 1986. С. 5-14.

94 Три года советского строительства в Дальневосточном крае. К первому дальневосточному краевому съезду советов рабочекрестьянских и красноармейских депутатов: отчет Дальревкома за 1922-25 год / Под ред. М.П. Копытина. Хабаровск, 1926. С. 19; VII Дальневосточная краевая конференция РКП (б) (16-20 XI 1925 г.): стенографический отчет Хабаровск, 1925. С. 33. 
сельское население было слабо охвачено правовой пропагандой. Но даже проводимая работа по распространению печатных изданий была малоэффективной из-за огромного числа неграмотного населения ${ }^{95}$.

В условиях ведения боевых действий наиболее эффективную работу по правовой пропаганде среди дальневосточного населения проводили политические органы Народно-революционной армии Дальневосточной республики (НРА ДВР). Роль армии в организации и проведении выборов в представительные органы буфера была определена I Дальневосточной партийной конференцией. Особую роль в пропаганде играли печатные формы, их многократное использование позволяло распространять знания, в том числе и в сфере права, среди широкого круга населения. Политический отдел НРА ДВР издавал газеты «Народоармеец», «Красный Восток», «Боец» и «Известия политотдела» печатные полосы которых были наполнены фронтовыми сводками и агитационными материалами. Текстуальный анализ газет для военнослужащих НРА ДВР свидетельствует, что они содержат информацию о конкретных фактах и событиях гражданской войны, в том числе и о правовых отношениях в этот период. Для привлечения широкого круга читателей статьи написаны понятным языком с применением крупного шрифта. Армейские коммунисты находясь в селах используя собрания крестьян разъясняли положения

95 К 1923 г. процент неграмотных в сельской местности Дальнего Востока составлял 64,5\%. А по официальным данным к концу 1920-х гг. неграмотными оставалось $64 \%$. Подробнее см.: Статистический ежегодник 1923-25 гг. Ч. 1. Хабаровск, 1925. С. 26-27; Лобов А.А. Культурное строительство на Дальнем Востоке. 1928. 30 мая. 
политики РКП (б), особенности внешнеполитической ситуации вокруг буфера, специфику его внутренней политики, а грамотные читали вслух газеты, обращения, листовки и проч. ${ }^{96}$. Однако информация, содержащаяся в печатных формах в динамичных условиях гражданской войны быстро устаревала. Это являлось серьезным недостатком для организаторов работы по пропаганде правовой информации.

Работа по пропаганде права среди дальневосточников стала приобретать массовый характер лишь с вхождением региона в состав РСФСР. Партийные и советские структуры Дальнего Востока постепенно трансформировались в утвержденную в РСФСР систему. Внешкольный отдел Министерства народного просвещения Дальневосточной республики был преобразован в политико-просветительный подотдел отдела народного образования Дальневосточного революционного комитета (Дальполитпросвет). Созданная структура занималась ликвидацией неграмотности и малограмотности, развивала сеть советских партийных школ в регионе, а также координировала работу изб-читален, народных домов, театров, кинотеатров, музеев, библиотек и клубов. К осени 1923 г. в регионе действовало 183 избычитальни, 30 народных домов, 118 клубов, 9 театров, 3 краевых музея и 1 государственная библиотека ${ }^{97}$.

В конце ноября 1922 г. циркуляром Дальневосточного бюро ЦК РКП (б) была подчеркнута важность изб-читален

${ }^{96}$ РГАСПИ. Ф. 372. Оп. 1. Д. 161. Л. 26.

${ }^{97}$ ГАХК. Ф. П-44. ОП. 1. Д. 624. Л. 1, 24, 26. 
в дальневосточной деревне ${ }^{98}$. Избы-читальни должны были стать центрами пропаганды советской политики в деревне. Дальневосточное крестьянство, не знавшее тягот продовольственной разверстки и продовольственного налога, негативно встречало реализацию принципов новой экономической политики. Земледельцы региона на протяжении первых двух десятилетий XX в. находились в привилегированном положении. Процесс заселения Дальнего Востока обусловил широкое распространение крупных хозяйств, поэтому установление подесятинной ставки налога ${ }^{99}$ и дополнительных сборов необходимых для восстановления экономики региона, а в последствии введение единого налога, было воспринято местным населением как продолжение грабительской политики периода гражданской войны. Опубликование декрета ЦИК и СНК РСФСР «О льготах беднейшему крестьянству по освобождению от уплаты единого сельскохозяйственного налога» ${ }^{100}$ требовало доведения его содержания до населения дальневосточных деревень. Отрицательный настрой народных масс обуславливал корректную работу специалистов по правовой пропаганде, основанную, прежде всего, на ненасильственных методах распространения информации. Огромную роль в решении этой задачи играл плакат. Тематика плакатов определялась задачами, стоявшими перед советским правительством в конкретный

98 Культурное строительство на Дальнем Востоке (1917-1941 гг.). Док. и материалы. Владивосток, 1982. С. 61-62.

99 О натуральном налоге на хлеб, картофель и масляные семена: постановление СНК РСФСР от 21 апреля 1921 г. // СУ РСФСР. 1921. № 38, ст. 204.

${ }^{100}$ СУ РСФСР. 1923. № 97, ст. 969. 
период. Зачастую авторы призывали к выполнению декретов и постановлений советского правительства и коммунистической партии. Плакаты, распространяемые в дальневосточных селах касалась развития сельского хозяйства, кооперации, налоговой политики, а также предвыборных кампаний ${ }^{101}$. С малограмотным населением проводились коллективные читки, разъяснение и обсуждение плакатов, содержащих постулаты большевистской идеологии.

Низкий уровень образования самих избачей приводил к тому, что толкование нормативных актов не всегда было верным и носило дилетантский характер. Кроме того, постановление СНК затронуло незначительную часть дальневосточного крестьянства, поэтому существенного влияния на формирование правосознания населения пропаганда этих нормативных правовых актов не оказывала. Культурно-просветительная работа на селе была осложнена нехваткой печатных средств массовой информации. Необходимость экономии обусловила и закрытие некоторых уездных изданий, например, в Сучане, Никольске, Спасске, Ольге, Зее и Свободном, а для сохраненных губернских газет и журналов тираж стал минимальным ${ }^{102}$. Поэтому крестьянство плохо было осведомлено о советской политике в дальневосточной деревне. В сложившейся ситуации из фондов государственного книжного издательства и

${ }^{101}$ ГАХК. Ф. П-44. Оп. 2. Д. 123; Д. 190. Л. 1; Д. 191. Л. 1; Д. 225. Л. 1; Д. 333. Л. 1; Д. 334. Л. 1; Д 337. Л. 1; Д. 338. Л. 1; Д. 339. Л. 1; Д. 341. Л. 1; Д. 342. Л. 1; Д. 348. Л. 1; Д. 350. Л. 1. Д. 352. Л. 1; Д. 353. Л. 1; Ф. Р-1713. Оп. 1. Д. 6. Л. 1-3; Д. 17. Л. 1-8; Д. 18. Л. 1-2; Д. 19. Л. 1-11.

102 Культурное строительство на Дальнем Востоке (1917-1941 гг.). Док. и материалы. Владивосток, 1982. С. 62-64. 
государственных библиотек РСФСР летом 1923 г. в регион была направлена литература, позволившая укомплектовать 35 библиотек изб-читален. В феврале 1924 г. Политпросвет Приморья разослал по избам-читальням еще 1156 экземпляров газет и журналов, а в мае того же года 206 экземпляров книг по различным вопросам сельской и общественной жизни ${ }^{103}$. Но значительное число неграмотных жителей села не позволяло эффективно использовать библиотечный фонд. Пропаганда идей советской власти в дальневосточных селах велась слабо, а информационный вакуум формировал условия для народных выступлений и антисоветских восстаний.

Огромную работу по правовой пропаганде среди советских граждан проводил агитационнопропагандистский отдел ЦК РКП (б) и его подразделения на местах. Практическая реализация поставленных партией задач осуществлялась через выступления сотрудников различных ведомств, перед населением. Например, сотрудники земельного отдела Дальневосточного революционного комитета с разъяснением положений Земельного кодекса РСФСР выступали на крестьянских собраниях, читали лекции на краткосрочных крестьянских курсах волостных секретарей, выпускали листовки и публиковали статьи в губернских крестьянских газетах, а также готовили материалы для докладов на крестьянских конференциях ${ }^{104}$. Подобные публичные выступления

${ }^{103}$ ГАХК. Ф. П-44. Оп. 1. Д. 624. Л. 1, 24, 27; Спешилова Е.В. Деятельность сельских культурно-просветительных учреждений Приморья в 1923-1925 гг. // Гуманитарные исследования в Восточной Сибири и на Дальнем Востоке. 2018. № 1. С. 76.

${ }^{104}$ РГИА ДВ. Ф. Р-285. Оп. 1. Д. 285. Л. 32. 
проводились редко ввиду загруженности сотрудников советского аппарата, отсутствия штата лекторов и просветителей, а в отдаленных селениях и вовсе воспринимались как чрезвычайное событие. Однако о первых успехах Агитационный отдел Дальбюро ЦК РКП (б) отчитался в Дальполитпросвет весной 1923 г. В документе отмечено, что в крае создана сеть изб-читален ${ }^{105}$, проведены мероприятия по распространению информации о советском законодательстве. Решение вопроса о привлечении грамотных граждан к правовой пропаганде в деревне нашло свое отражение в Постановлении ЦК РКП (б) «О работе РКП в деревне» ${ }^{106}$, которое обязывало школьных учителей участвовать в пропаганде законов и декретов советской власти. Воспоминания одного из педагогов приморской деревни Успенка (ныне - п. Кировский, Приморского края) ярко рисуют картину участия педагогов в просветительской и агитационной работе среди сельских жителей ${ }^{107}$. Мемуары описывают насыщенную жизнь школьного учителя, свидетельствуют о желании педагогов превозмогая бытовые трудности заниматься распространением знаний среди населения. Но показаны и сложности реализации этой работы связанные с отсутствием помещения, финансирования, противодействия части населения распространению советского права. Таким образом говорить о массовости

105 Народное просвещение на Дальнем Востоке в 1924-1925 учебном году Б.м, 1925. С. 35.

106 О работе РКП в деревне (Постановление ЦК РКП во исполнение решений ХІІ Съезда РКП) - Тюмень, 1923.

${ }^{107}$ Ниязов С. Культармейцы. Приморскому комсомолу - 50 лет. // Красное знамя. 1970. 27 окт. 
правовой пропаганды в селах региона в рассматриваемый период не приходится.

Направления и содержание работы в деревне определялись циркуляром ВЦИК и СНК РСФСР от 18 сентября 1924 г., в котором указывалось, что одной из задач их деятельности была пропаганда советского законодательства ${ }^{108}$. В избахчитальнях проводились громкие читки положений о выборах, обсуждалось советское законодательство в том числе о сельскохозяйственном налоге и землепользовании. Избачи организовывали обсуждение статей из журналов посвященных правовым проблемам села, например, в газетах «Красный молодняк» и «Бурят-монгольская правда» обсуждались проблемы нарушения молодыми людьми общественного порядка ${ }^{109}$. В газете Сахалинского бюро РКП (б) «Советский Сахалин» с 1925 г. действовала постоянная рубрика юридической консультации для крестьян $^{110}$. В центральных и губернских печатных изданиях публиковались статьи о Конституции СССР, Конституции РСФСР, освещалось законодательство о выборах, а также вопросы по организации сельских советов. Например, в 1927 г. в газете «Приморский крестьянин» о перевыборах было опубликовано 26 статей, освещавших различные аспекты перевыборов. Публиковались сведения об организации перевыборов в сельских районах Приморья, опубликовано 9 бесед с беднотой об организации избирательных участков ${ }^{111}$. В Амурской и Приамурской губерниях специально к выборам

${ }^{108}$ ГАХК. Ф. П-2. Оп. 11. Д. 36. Л. 38.

109 Красный молодняк. 1922. 12 марта; Бурят-монгольская правда. 1925. 17 янв.

${ }^{110}$ РГАСПИ. Ф. 372. ОП. 1. Д. 980. Л. 227.

${ }^{111}$ ГАХК. Ф. П-2. Оп. 11. Д. 6. Л. 69. 
издавали предвыборные газеты «Крестьянский листок» и «Амурский крестьянин», а также специальные приложения «Страничка крестьянина», «Страничка работницы», «Страничка молодого коммунара». Широко издавались плакаты и листовки, посвященные положениям о выборах. Например, в Забайкалье были растиражированы брошюры «Что такое Советы и кто ими должен руководить?», а в уездах и волостях Приамурья брошюры с выдержками из Конституции СССР, Конституции РСФСР и Положения о сельских Советах ${ }^{112}$. В помощь избачам, руководителям клубов, а также пропагандистам и агитаторам выходили карманные издания $^{113}$.

Активная работа с сельским населением проводилась и в зимний период. Избачи и пропагандисты из числа активной комсомольской молодежи популяризировали среди односельчан инструкцию о перевыборах, принципы советских перевыборов, рассказывали об основных положениях социального страхования, и принципах налогообложения, читали лекции о борьбе с хулиганством, безработицей, выступали на женских собраниях делегаток, привлекали к пропаганде советского законодательства членов партийных ячеек и сельских старост ${ }^{114}$. С молодежью призывного возраста проводилась агитационнопропагандистская работа по разъяснению Закона об

112 РГИА ДВ. Ф. Р-2422. Оп. 1. Д. 319. Л. 165.

113 Озеров М. Просветительная работа по кооперации. М-Л., 1926; Мартынов М.И. Единый сельскохозяйственный налог 1926/1927 года в условиях Дальне-Восточного края (пособие для докладчиков, пропагандистов, сельской интеллигенции и беспартийного крестьянского актива). Хабаровск, 1926.

${ }^{114}$ ГАХК. П-2. ОП. 11. Д. 2. Л. 99-100, 113; Д. 3. Л. 24-28. 
обязательной военной службе, популяризация приказов, циркуляров и директив, изданных в связи с очередным призывом. А также ознакомление призываемых и населения с законодательством о льготах по призыву, преимуществах предоставляемых семьям красноармейцев ${ }^{115}$.

Во второй половине 1920-х гг. появились новые формы работы с населением. В красных уголках и избах-читальнях обустраивались витрины-доски с газетными и журнальными вырезками, обобщенной политической информацией, обустраивались ящики и доски вопросов и ответов. Появились устные и стенные газеты, посвященные актуальным вопросам правовой пропаганды в деревне. Появление «живой газеты», а точнее инсценировки на актуальную тему, стало новой формы пропагандистской работы. Ставились спектакли и инсценировки на тему перевыборов ${ }^{116}$. Участники действа придумывали запоминающиеся рифмы, которые затем расходились среди сельчан. Такая форма пропаганды способствовала привлечению большего числа жителей дальневосточных деревень к проводимым мероприятиям. Однако положительные результаты агитационно-пропагандистской работы имелись не во всех районах. Так, в отчете о работе изб-читален Михайловского района Амурской области за 1927 г. отмечено, что избачи слабо участвуют в организации общественности, проводят мероприятия на низком уровне, «откровенно халтурят», а в Свободненском районе Амурской области и на Камчатке слабо проводилась

115 ГАХК. П-2. Оп. 4. Д. 136. Л. 93; Оп. 11. Д. 46. Лл. 31, 45, 66; Д. 47. Л. 12; Д. 51. Л. 53; Д. 53. Л. 6; Д. 57. Л. 42.

116 Там же. Оп. 3. Д. 21. Л. 2-3; Оп. 11. Д. 2. Л. 113; Д. 6. Л. 123. 
массовая работа по организации перевыборов в сельские советы $^{117}$. Правовое просвещение сельчан осуществлялось и на проводимых на Дальнем Востоке 9-недельных крестьянских курсах по программе Главполитпросвета. Слушатели знакомились не только с политической грамотой, но и изучали советское законодательство и особенности его реализации в сельскохозяйственной политике ${ }^{118}$. Активная работа по правовой пропаганде постепенно способствовала формированию положительных взглядов сельского населения на советскую политику в дальневосточной деревне, снижению уровня классовой напряженности, сокращению числа антисоветских выступлений.

Развернувшаяся в регионе к середине 1920-х гг. массовая борьба с неграмотностью позволила увеличить число грамотного сельского населения. Мероприятия советских и партийных органов по ликвидации безграмотности и малограмотности позволили эффективно проводить агитационные и пропагандистские мероприятия. В период предвыборных кампаний, кампаний по снижению цен, развитию кооперации, получения сельскохозяйственного кредита и проч. избычитальни, а также сельские клубы и красные уголки становились центрами правовой пропаганды и агитации. Огромное значение приобрела наглядная визуальная пропаганда. Появилось большое количество лозунгов, плакатов, организовывался и проводился Международный день кооперации, в клубах ставились пьесы, в школах проводились занятия на тему «Кооперация, принципы ее

${ }^{117}$ ГАХК. Ф. П-2. Оп. 3. Д. 277. Л. 10-11; Оп. 11. Д. 91. Л. 7; Д. 104. Л. 4. 118 Там же. Оп. 11. Д. 40. Л. 92. 
построения и значение в поднятии сельского хозяйства» $^{119}$. Активно использовались печатные средства массовой информации, например, газет «Приморский крестьянин» издавала еженедельное приложение «Приморская деревня» в котором освещались задачи сельской кооперации, нормативная документация, связанная с деятельностью кооперативов, рассказывалось о кооперативных объединениях и их видах.

Огромное внимание стало уделяться киноискусству, как средству пропаганды. Первая государственная организация «Госкино» было образовано в 1924 г., а уже на следующий год появилось «Совкино» и его отделение - «Далькино». «Совкино» обладало монопольным правом демонстрации советских кинокартин, что позволяло существенно удешевить, a, следовательно, и расширить демонстрацию кинофильмов распространив ее не только на городское население, но и на сельское. Темами обсуждения в деревне становились бесплатные кинопоказы документальных и агитационных лент, приуроченных к советским праздникам. Так в 1920-е гг. в прокат были выпущены художественные и документальные фильмы в которых опосредованно раскрывались советские правовые нормы, рассказывалось о деятельности следственных органов, суда и прокуратуры, а также темы выборов советских органов власти, кооперирования и восстановления села ${ }^{120}$.

119 ГАХК. Ф. П-2. Оп. 11. Д. 3. Л. 7, 29; Д. 6. Л. 47; Д. 7. Л. 12; Д. 40. Л. 30; Д. 46. Л. 2-3; Д. 56. Л. 14; Д. 59. Л. 36-37, 40-41; Д. 66. Л. 30; Д. 103. Л. 9, 13; Д. 119. Л. 28; Д. 124. Л. 10-11; Д. 131. Л. 8-9; Ф. П-618. Оп. 1. Д. 24. Л. 9-10.

120 По закону (реж. Л. Кулешов,1926 г.), Проститутка (реж. О. Фрелих, 1926 г.), Шагай, Совет! (реж. Д. Ветров, 1926 г.), Девушка 
Общесоюзное увлечение радио достигло и Дальнего Востока, постепенно в регионе развивалось радиовещание. С января 1923 г. во Владивостоке действовал кружок радиолюбителей. Печатные издания Владивостока, Хабаровска, Благовещенска и Читы тиражировали информацию об устройстве радиоприемника и развитии радиосети в стране. К началу 1926 г. приморская радиовещательная станция начала транслировать радиогазеты сначала 3, а потом и 5 раз в неделю. Быстрое распространение радиовещания способствовало тому, что к концу 1927 г. в Дальневосточном крае действовало около 2 тыс. радиоустановок, которые к 1929 г. работали ежедневно по твердой эфирной сетке. Радиослушателям были доступны пионерские и комсомольские радиогазеты, радиожурнал «Октябренок», а также рабочая газета и радиогазета для китайских и корейских тружеников Дальнего Востока.

На рубеже 1920-1930-х гг. произошел новый всплеск социальной напряженности в дальневосточной деревне. Крестьяне-старожилы региона, не знавшие уравнительного землепользования, продовольственной разверстки и продовольственного налога не поддержавшие нововведения советской аграрной политики, связанные с продовольственным и денежным налогообложением, также отрицательно отнеслись к идее коллективизации крестьянских хозяйств. Тогда как бедняцко-середняцкая масса напротив поддержала коллективизацию села. С учетом ошибок и перегибов реализации ранее принятых

с коробкой (реж. Б. Барнет, 1927 г.), Суд должен продолжаться (реж. Е. Дзиган, Б. Шрейбер, 1930 г.) и др. 
постановлений советской власти, руководством страны было принято решение о постепенном распространении знаний о советской аграрной политике, в том числе и среди крестьян Дальнего Востока. Поэтому пропаганда преобразований в деревне разворачивалась постепенно с 1927 г., в ее ходе агитаторы выезжали в районы разъясняли принципы социализма и демонстрировали примеры из кинофильмов объединения крестьянских хозяйств ${ }^{121}$, отвечали на вопросы колхозников о приеме в колхозы и порядке их оформления, помощи государства в случае стихийных бедствий, землеустройстве и кредитовании ${ }^{122}$. В дальневосточных печатных средствах массовой информации ориентированных на сельских жителей с каждым годом увеличивалось количество публикаций об успехах посевных и уборочных кампаний, колхозном строительстве и коллективизации ${ }^{123}$. А в газете «Путь дальневосточного крестьянина» появился раздел «Крестьянский справочник» в которых отвечали на вопросы читателей.

В 1930 г. была начата сплошная коллективизация крестьянских хозяйств Дальнего Востока, основными задачами которой были ликвидация мелкотоварного крестьянского хозяйства и создание обобществленного

121 Бабы рязанские (реж. С. Дрезинин, 1927 г.), Старое и новое (реж. С. Эйзенштейн, Г. Александров, 1929 г.), Земля (реж. А. Довженко, 1930 г.) и др.

${ }^{122}$ ГАХК. Ф. П-2. Оп. 11. Д. 56. Л 7.

123 Льготы красноармейским колхозам // Путь дальневосточного крестьянина. 1930. № 1. С. 57; О распределении имущества в колхозах и о леспопользовании // Путь дальневосточного крестьянина. 1930. № 2. С. 60; О дифференцированном пае // Путь дальневосточного крестьянина. 1930. № 2. С. 61 и др. 
крестьянского производства. Идеи коллективизации дальневосточным населением были встречены без энтузиазма, а в приграничных районах Дальневосточного края, заселенных зажиточными крестьянами и бывшими казаками и вовсе враждебно. По указанию органов государственной власти в сельских районах региона проводились читки законодательства и беседы о нормативном правовом регулировании деятельности коллективных хозяйств ${ }^{124}$, распространялись листовки и плакаты рисовавшие положительные аспекты коллективизации. Все это вызывало яростное сопротивление сельчан, не желавших вступать в колхоз. Участились случаи антисоветской агитации, избиений и убийств колхозных активистов, уничтожения имущества, самораскулачивания и фиктивного раздела крупных хозяйств $^{125}$. Все это провоцировало советские структуры применять насильственные методы коллективизации, обостряя и без того сложную обстановку в деревне. Попытки крестьян защитить свою собственность квалифицировались как «вылазка классового врага», и, через пропаганду постановления СНК СССР «О признаках кулацких хозяйств, в которых должен применяться кодекс законов о труде» и Директивы Далькрайкома ВКП(б) от 18 февраля 1930 г. с разъяснением этапов и методов проведения ликвидации кулачества началась борьба с кулачеством и насильственная организация колхозов.

В таких непростых условиях агитационнопропагандистская работа стала одной из важных и остро

${ }^{124}$ ГАХК. Ф. П-2. Оп. 4. Д. 136. Л. 241-243.

125 Там же. Оп. 1. Д. 237. Л. 4. 
нуждалась в расширении приемов и средств. Одно из ведущих мест в агитационно-пропагандистской работе заняло радиовещание. По радио передавали не только важные правительственные сообщения, но и транслировали передачи, рассказывающие об успехах колхозного строительства, трудовом героизме, выполнении пятилетних планов и проч. Выпускалась газета «Крестьянская радиоправда», радиостудии приглашали известных партийных и профсоюзных лидеров, которые освещали достижения советского строя, транслировали заседания съездов, конференций и совещаний. Основной аудиторией для пропагандистской работы становились представители бедняцких хозяйств таким образом власть укрепляла свои позиции в деревне и расширяла социальную базу сторонников коллективизации.

Еще одним способом агитационно-пропагандистской работы, направленной на реализацию принципов колхозного строительства стали кинопередвижные станции. Киносеть развивали в районах сплошной коллективизации, машиннотракторных станций, охватывали рабочие и национальные поселки. Перед сеансами агитаторы проводили политинформацию, рассказывали об успехах советского строительства, вещали о правах и обязанностях сельского населения, нередко демонстрировали хронико-документальные фильмы об успехах развития Дальнего Востока.

Часть дальневосточного крестьянства поддерживала мероприятия по колхозному строительству, а некоторые из крестьян сами призывали односельчан объединиться, такие примеры имеются и в с. Шилка Читинского округа и в с. Могилевка Хабаровского округа и в с. Анучино 
Владивостокского округа, активное участие в пропаганде колхозов принимали и бывшие партизаны ${ }^{126}$. Однако ошибки отдельных руководителей местного колхозного строительства, порой неоправданно жесткие меры борьбы с кулачеством и лицами, не желавшими вступать в колхозы, общий низкий уровень понимания проводимых реформ, а также нехватка агитаторов, способных квалифицированно донести идеи и перспективы колхозного строительства приводили к увеличению оттока крестьян из колхозов и создавали наряженную обстановку в деревне.

С созданием в конце 1930-х гг. колхозно-совхозной системы вновь была активизирована пропаганда проводимых мероприятий. Сельским жителям разъясняли правовое поле закона «О мерах охраны общественных земель колхозов от разбазаривания», рассказывали содержание постановлений партии и советского правительства об изменениях в политике хлебозаготовок и закупок сельскохозяйственных продуктов, мероприятиях по повышению урожайности и продуктивности животноводства и т.д. ${ }^{127}$. Основными способами разъяснительной работы оставались беседы в избах-читальнях и станах, выступления пропагандистов и представителей советских властных структур на собраниях колхозников, работа кружков политической грамоты, а также широкое использование средств массовой информации. Центральными издательствами выпускались брошюры, содержащие темы бесед с колхозниками. Например, пропагандисты рассказывали крестьянам о задачах уборочной кампании, бюджете СССР и

${ }^{126}$ ГАХК. Ф. П-2. Оп. 1. Д. 237. Л. 2-3, 8-9, 165.

${ }^{127}$ ГАХК. Ф. П-35. Оп. 1. Д. 559. Л. 57-59; Оп. 3. Д. 36. Л. 8; Д. 112 Л. 44; Д. 1096. Л. 53. 
государственном страховании, государственном плане развития животноводства ${ }^{128}$. Советское киноискусство выпустило в прокат документальные и художественные фильмы, которые демонстрировали кинопередвижки и кинотеатры $^{129}$. А самодеятельные театры занимались постановкой агитационных судов. Подготовка театрализованного действа предполагала «проживание» характеров героев в ходе инсценировки судебного процесса, что позволяло формировать у зрителей представление о работе следствия, судебных органов и прокуратуры. Итоги проведенной работы были более успешны. Социальное напряжение в дальневосточной деревне практически не проявлялось, разъяснительная работа положительно влияла на трудовую дисциплину, а превентивные мероприятия по профилактике правонарушений с привлечением сотрудников советских судебных органов и прокуратуры и вовсе способствовали значительному сокращению противоправных действий в деревне.

К середине 1930-х гг. были сформированы государственный плановый сектор экономики, многоукладная экономическая структура, а правовой статус социально-классовых групп трансформировался. Bce это способствовало пересмотру формы государственного управления, которая была реализована в Конституции СССР 1936 г. и Конституции РСФСР 1937 г. Конституционные преобразования затронули и

128 Подробнее см.: Закрепить успехи избирательной кампании по выборам в Верховный Совет РСФСР. Сб. материалов в помощь пропагандисту и агитатору. Ростов - на - Дону, 1938.

${ }^{129}$ Гармонь (реж. И. Савченко, 1934 г.), Крестьяне (реж. Ф. Эрмлер, 1935 г.), Трактористы (реж. И. Пырьев, 1939 г.) и др. 
избирательное право, сделав его всеобщим, что повлекло необходимость проведения перевыборов советских органов власти по все стране. Поэтому в рассматриваемый период агитационно-пропагандистская работа по правовому просвещению населения проходила в русле реализации задач, связанных с выборами в Верховный Совет СССР назначенными на 12 декабря 1937 г., в Верховный Совет РСФСР назначенными на 26 июня 1938 г. и в краевые областные, окружные, районные, городские, сельские и поселковые советы трудящихся РСФСР.

Избирательное законодательство формировалось постепенно, поэтому пропагандистская работа постоянно расширялась. Разъяснив населению новеллы и процедуру одних выборов, приняв участие в избирательной кампании пропагандисты тут же принимались за подготовку следующих. Учитывая сложность и масштабность проводимой работы центральные партийные органы обеспечивали свои низовые кадры методическими материалами. Циклы бесед детально разрабатывались агитационно-пропагандистскими отделами и направлялись на места. Примерные темы касались дня выборов, утверждения состава избирательных комиссий, формирования избирательных округов и проч. ${ }^{130}$. На предприятиях и учреждениях, в колхозах и сельсоветах создавались кружки по изучению положений о выборах.

${ }^{130}$ О выборах в Верховный Совет РСФСР. Сб. материалов. Хабаровск, 1938; Примерная программа бесед для изучения «Положения о выборах» в краевые, окружные, районные, городские, сельские и поселковые Советы депутатов трудящихся РСФСР. Омск, 1939. 
Активную работу по предвыборной агитации провели дальневосточные комсомольцы. Все райкомы ВЛКСМ и комсомольские организации школ, училищ, техников и институтов провели с учащимися беседы о необходимости изучения Конституции СССР, организовали и провели социалистическое соревнование среди обучающихся «за отличное знание конституции», организовывали работу политических школ и кружков. В соответствии с постановлениями Дальневосточного краевого комитета ВЛКСМ комсомольцы проводили собрания учащейся, рабочей и колхозной молодежи, активно взаимодействовали с избирательными участками, разъясняли населению лозунги и плакаты, посвященные выборам $^{131}$. Первые выборы по новым принципам прошли в декабре 1937 г. Архивные документы свидетельствуют, что выборная кампания в Верховный Совет СССР прошла с замечаниями, которые были вызваны слабой агитационно-пропагандистской работой, организационными недостатками, неэффективной работой агитаторов ${ }^{132}$. Но в целом, партийные и советские структуры были удовлетворены ее итогами.

Наиболее широко агитационно-пропагандистская кампания в дальневосточной деревне была проведена в рамках предвыборной кампании 1938 г. Изменение нормативной правовой базы, вкупе с требованиями партийного руководства высокой явки избирателей

${ }^{131}$ ГАХК. Ф. П-618. Оп. 1. Д. 312. Л. 97, 126; Д. 314. Л. 14.

132 Там же. Ф. П-2. Оп. 1. Д. 1302. Л. 248-249; Д. 1547. Л. 39-41; Оп. 11. Д. 6,7, 12, 13, 15, 17; Ф. П-35. Оп. 1. Д. 2. Л. 58-59; Ф. Р-719. Оп. 6. Д. 94. Л. 22; Д. 99 Л. 22. 
обусловили развертывание агитационно-пропагандистской работы. В соответствии с директивами центрального руководства агитатор должен был посетить каждую семью на участке, с каждым провести разъяснительную беседу и ответить на возникшие вопросы. Подготовительная работа к выборам в Верховный Совет РСФСР началась в феврале 1938 г., когда на места стали поступать первые директивы о предвыборной кампании. Помимо молодежи к агитационной работе было решено привлечь опытных партийцев. В апреле 1938 г. районные комитеты ВКП (б) направили в села партийно-комсомольский актив для организации подбора кандидатов в состав участковых избирательных комиссий. В задачу актива входило и разъяснение основ советского избирательного права ${ }^{133}$. В это же время партийным руководством районов проведены совещания по вопросам подготовки политикопросветительных учреждений к выборам в высший орган государственной власти РСФСР ${ }^{134}$. Такая подготовка дала результаты. Например, в Завитинском районе весной 1938 г. действовало 54 кружка в работе которых приняло 305 агитаторов. А в Бикинском районе в 120 населенных пунктах были организованы и проведены митинги участие в которых приняло 7500 чел. ${ }^{135}$. С апреля по июнь 1938 г. в кружках, действовавших при домах культуры Дальневосточного региона развернулась работа по изучению норм Конституции СССР 1936 г., Конституции РСФСР 1937 г. и положений советского избирательного

${ }^{133}$ ГАХК. Ф. П-2. Оп. 11. Д. 253. Л. 2.

${ }^{134}$ Там же. Д. 240. Л. 6.

135 Там же. Д. 220. Л. 1-2, 5. 
законодательства. В избах-читальнях для сельского населения были прочитаны лекции о новеллах избирательного права, активисты ВЛКСМ проводили занятия с молодежью и домохозяйками на которых разбирали схему государственного устройства РСФСР и технику голосования ${ }^{136}$. Правовое просвещение затронуло и иностранных рабочих. Например, в Благовещенске в клубе китайских и корейских рабочих иностранным коммунистам разъясняли положения «Сталинской Конституции» ${ }^{137}$. Такие цифры свидетельствуют не только о массовости, но и об эффективности работы агитаторов, которые сумели привлечь к участию народные массы.

После завершения уборочной страды 1938 г. в сельские районы Дальнего Востока были направлены агитаторы, агитационные коллективы, агитационные машины и поезда для распространения знаний о положениях Конституции СССР, Конституции РСФСР и законодательства о выборах в местные Советы депутатов ${ }^{138}$. Прибывшие пропагандисты устраивали праздники в честь Конституции, на которых в игровой форме рассказывали нововведения, касающиеся непосредственно целевой аудитории, организовывали коллективные прослушивания грамзаписей докладов И.В. Сталина и В.М. Молотова, демонстрировали агитационно-пропагандистские кинофильмы, организовывали громкие читки газет, плакатов и иных печатных форм ${ }^{139}$.

${ }^{136}$ ГАХК. Ф. П-2. Оп. 11. Д. 222. Л. 1; Д. 240. Л. 3-4, 6, 11-14; Д. 250. Л. 1; Д. 252. Л. 3-6; Д. 253. Л. 1-2, 4-6, 7, 9, 17, 19, 25-26.

137 Там же. Д. 222. Л. 1.

${ }^{138}$ Там же. Д. 250а. Л. 3.

139 Там же. Д. 247. Л. 138; Д. 250. Л. 87, 95-96, 99, 100; Ф. П-35. Оп. 1. Д. 189. Л. 44. 
Однако агитационно-пропагандистская работа носила нерегулярный характер и во многом зависела от проводивших ее личностей. Так, например, имелись случаи срыва этой работы в Завитинском районе Амурской области и в Посьетском районе Приморского края ${ }^{140}$. Анализируя избирательные кампании 1937-1939 гг. в целом необходимо отметить массовый электоральный подъем, которому способствовала в том числе и проведенная агитационнопропагандистская работа.

В начале 1940-х гг. пропагандистская работа не была столь широкой. Продолжилось информирование населения о значимых положениях советского законодательства, касающегося налогообложения и трудовой недели, в условиях военного времени активизировалась справочная работа. В домах-культуры и избах-читальнях разъяснялись постановления СНК СССР и ЦК ВКП (б), например, внимание сельской общественности привлекло постановление партии и правительства «О дополнительной оплате труда колхозников за повышение урожайности и продуктивности животноводства». Кроме того, выдавали справки, юристы проводили консультации, организовывались вечера вопросов и ответов по правам и обязанностям советских граждан, составлялись заявления в государственные инстанции, работники суда и прокуратуры разъясняли сущность революционной законности, говорили об ужесточении ответственности за отдельные виды правонарушений, приводили примеры из

${ }^{140}$ ГАХК. Ф. П-2. Оп. 11. Д. 250. Л. 3, 24-25, 52, 57; Д. 250а. Л. 44. 
практики ${ }^{141}$. Таким образом работа по правовому просвещению сельского населения продолжилась, но изменила свой вектор.

Городское население Дальнего Востока было относительно немногочисленным, сказывался аграрный характер производства и незначительное, по сравнению с центральными регионами РСФСР, число промышленных предприятий. Завершение периода восстановления и начало процесса индустриализации экономики региона сопровождалось увеличением численности городского населения. Культурно-просветительная работа в дальневосточных городах проводилась через рабочие клубы $^{142}$, а с середины 1920-х гг. агитаторы и пропагандисты стали выступать перед рабочими и служащими в обеденные перерывы. Тематика бесед определялась агитационно-пропагандистским отделом ЦК ВКП (б) и опубликовывалась в виде карманных брошюр ${ }^{143}$. Проведение предвыборных кампаний и допризывная подготовка также не обходили стороной горожан ${ }^{144}$. Однако наиболее ярко проводилась кампания за снижение цен. Так, в 1927 г. в приморских городах проводились общегородские собрания агитаторов, представителей партийных ячеек коллективов, а также квартальные собрания покупателей, на которых разъяснялись примеры

${ }^{141}$ ГАХК. Ф. П-35. Оп.3. Д. 1096. Л. 14-15, 17, 24, 37, 39, $52,53$.

${ }_{142}$ КПСС в резолюциях и решениях съездов. Т. 3. 1924-1927. М., 1970. C. 275.

${ }^{143}$ См.: Соколов К. Быть достойным своей прекрасной Родины (об обязанностях граждан СССР) // Спутник агитатора. 1937. № 2.

${ }^{144}$ ГАХК. Ф. П-2. Оп. 4. Д. 136. Л. 93; Оп. 11. Д. 2. Л. 68; Д. 101. Л. 4-5. 
реального снижения цен ${ }^{145}$. В приморских газетах «Красная Звезда» и «Рабочий кооператор» публиковались статьи и заметки освещавшие государственную политику по снижению цен.

Печатные и радийные средства массовой информации рассказывали о пятилетних планах, их выполнении, стремлениях трудящихся перевыполнить директивы советского руководства. Содержание большинства радио и печатных газет регулировалось указаниями Москвы.

Решения V Всесоюзного съезда Советов о пятилетнем планировании развития народного хозяйства СССР также были активно отражены в плакатах, газетах, радиопередачах, художественных и документальных кинофильмах. Агитаторы и пропагандисты убеждали советских граждан в имеющихся достижениях советского строя и мотивировали их на участие в дальнейших мероприятиях.

Агитационно-пропагандистская работа среди горожан проводилась на предприятиях, но постепенно разворачивалась и в жилых массивах, так, например, активно пропагандировалось постановление ЦК ВКП (б) «О мерах по упорядочению управления посредством и установлению единоначалия», популяризировался указ Президиума Верховного Совета СССР «О государственных трудовых резервах», а также указы о переходе на 8-часовой рабочий день, 7-дневную рабочую неделю и о запрещении самовольного ухода рабочих и служащих с предприятий и учреждений ${ }^{146}$. В помощь специалистам, проводившим эту

${ }^{145}$ ГАХК. Ф. П-2. ОП. 11. Д. 6. Л. 112.

${ }^{146}$ Там же. Оп. 4. Д. 136. Л. 233; Ф. П-30. Оп. 1. Д. 536. Л. 3-4, 12; Ф. П-35. Оп. 1. Д. 599. Л. 86, 208. 
работу отдел пропаганды и агитации Далькрайисполкома ВКП (б) выпускал журнал «Пропагандист-агитатор», дальневосточный профсоюз еженедельную газету «Рабочий путь». Активно развивалась кружковая работа по изучению Конституции СССР, Конституции РСФСР и законодательства о выборах, по вечерам на избирательных участках читали лекции и доклады, организовывали вечера встреч с кандидатами и демонстрировали кинофильмы ${ }^{147}$. Горожане, как и сельские жители Дальнего Востока приняли активное участие в избирательных кампаниях второй половины 1930-х гг. В целом, информированность дальневосточников о сути советского законодательства и процедуре выборов была высокой.

Расширение содержания правовой пропаганды населения Дальнего Востока потребовало от партийных органов региона организации курсового обучения специалистов занимавшихся агитационно-пропагандистской работой. С 1923 г. в дальневосточных советских партийных школах курсанты 2 ступени в количестве 60 часов изучали «Учение о праве и государстве в связи с Конституцией РСФСР» ${ }^{148}$. С сентября 1925 г. Отделом народного образования Дальневосточного революционного комитета проводились 8 и 12-дневные курсы-конференции для работников политикопросветительных учреждений Дальнего Востока, на которых в рамках правовой пропаганды предлагалось обсудить с населением «Положение о едином сельскохозяйственном налоге, устраивать громкие читки газет «Беднота» и

${ }^{147}$ ГАХК. Ф. П-2. ОП. 11. Д. 250. Л. 35; Ф. П-35. Оп. 3. Д. 56. Л. 8990, 92-97.

${ }^{148}$ ГАРФ. Ф. Р-393. Оп. 72. Д. 386. Л. 4. 
«Тихоокеанская звезда», а также принять активное участие в кампании 1926 г. по перевыборам в сельские советы, «уделяя внимание рассмотрению не только бытовых, но и юридических вопросов» ${ }^{149}$. В 1927 г. в Хабаровске были организованы 9-недельные курсы по программе Главполитпросвета, на которых в цикле обществоведения изучалось советское законодательство и особенности его реализации в деревне ${ }^{150}$.

В конце 1926 г. партийное руководство Дальневосточного региона реализуя указания ЦК РКП (б) инициировало вопрос о создании Информационного бюро по пропаганде права, которое после долгих прений было сформировано в составе представителей краевой прокуратуры, краевого суда, дальневосточного отдела народного образования, культурного отдела дальневосточного краевого совета профессиональных союзов и представителя административного отдела Дальневосточного краевого исполнительного комитета. Члены Бюро были единодушны в основных направлениях работы: пропаганда законности на конференциях, съездах и собраниях советских работников, правовое просвещение на разного рода курсах (избачей, сотрудников органов милиции, волостных писарей и проч.), правовое просвещение среди корреспондентов средств массовой информации, правовое просвещение народных заседателей и общественных обвинителей, а также заключенных ${ }^{151}$. Понимая важность организуемой ими

${ }^{149}$ ГАХК. Ф. П-2. Оп. 11. Д. 2. Л. 2, 4; Д. 36. Л. 22, 38, 52, 56-57.

150 Там же. Д. 40. Л. 92.

${ }^{151}$ Там же. Л. 3-4. 
работы высказывались предложения об организации оказания постоянной юридической помощи рабочим и крестьянам на местах, например, через формирование юридических кружков при избах-читальнях, т.к. «вопросы о хулиганстве, пьянстве, переселении, перевыборах в советы и прочем нуждаются в широком освещении среди народных масс» ${ }^{152}$. Членами Бюро в короткие сроки были разработаны «Положение о Бюро по пропаганде права» и план его работы на полугодие. В продолжение этой работы агитационнопропагандистская коллегия Агитационно-пропагандистского отдела Дальневосточного краевого комитета ВКП (б) обосновала необходимость создания окружных бюро пропаганды права и дала указания на места об их развертывании. Однако в июле 1927 г. подводя первые итоги этой работы коллегия констатировала «наличие на местах лишь зачатков систематической работы по пропаганде права (справочная работа, отдельные беседы, доклады)», выявленные недостатки связывались со слабой работой членов Бюро, несовершенством отчетности и нехваткой работников прокуратуры. В качестве мер по активизации деятельности по пропаганде права предлагалось пополнить библиотеки клубов и изб-читален популярной справочной и юридической литературой, расширить пропаганду права на страницах печати, а также «приблизить работу суда к крестьянским массам путем организации хорошо подготовленных показательных процессов ${ }^{153}$. В марте 1929 г. Коллегия Народного комиссариата юстиции работу по пропаганде права, а

${ }^{152}$ ГАХК. Ф. П-2. Оп. 11. Д. 40. Л. 5.

${ }^{153}$ Там же. Л. 136-137; Д. 43. Л. 75-76; Д. 44. Л. 44. 
также предоставление юридической помощи населению через консультации при избах-читальнях, домах крестьянина, колхозах и т.д. возложила на Верховный суд, который, в свою очередь разработал и разослал свой циркуляр краевым и областным судам. В документе даны подробные указания о конкретных формах и методах работы с населением. Кроме того, указано, что судебные органы регионов обязаны прикрепить своих работников к профсоюзным консультациям для наблюдения за предоставлением юридической помощи. Информационное бюро по пропаганде права начало деятельность, однако его работа затруднялась недостатком квалифицированных специалистов в органах суда и прокуратуры, которые должны были проводить работу с населением.

В 1927 г. Дальневосточный краевой отдел народного образования подготовил и разослал на места Инструктивное письмо в котором содержалась Программа бесед для юридических кружков работавших при избахчитальнях и красных уголках. В предисловии к документу отмечалось, что работа должна вестись по двум линиям: среди членов сельсоветов и остального населения села. Среди работников советского аппарата требовалось разъяснить как должны работать советские органы, что должны знать их руководители, чтобы работать правильно и не нарушать советские законы, а среди населения разъяснять «что от него может требовать советский аппарат и как этот аппарат должен обслуживать нужды населения. Пропагандировать основные законы, например, по избирательному праву; о семье и браке; о земле. Разъяснять к кому, куда и как нужно жаловаться в случае 
нарушения прав отдельных граждан или вообще плохой работы советского аппарата» ${ }^{154}$. Предложенная Программа включала в себя цикл из 20 бесед которые раскрывали государственный строй РСФСР и СССР; назначение, структуру и основные направления деятельности советских судов и прокуратуры; теорию и практику трудового и земельного законодательства, а также реализацию Лесного кодекса РСФСР. Отдельное направление правового просвещения составляли беседы о налогообложении и сельскохозяйственном кредитовании в рамках которых разъяснялись права и обязанности жителей села по видам и способам уплаты налогов, а также о возможностях займов. Значительное внимание уделялось и социальным вопросам. Так, обращалось внимание на советское понимание брака, права и обязанности супругов, детей и родителей, а также подробно освещались льготы военнослужащим и их семьям $^{155}$. В помощь проведения этой работы, в том числе и среди жителей города, выпускались центральные и региональные журналы («Изба-читальня», «Рабочий путь»), практические руководства, в которых более детально расписывалось содержание бесед и занятий с сельским населением ${ }^{156}$.

Начало сплошной коллективизации обернулось для сотрудников изб-читален, красных уголков и клубов привлечением к «колхозному строительству». В городах

154 Инструктивное письмо № 8 Дальневосточного краевого Отдела народного образования. Хабаровск, 1927. С. 39.

155 Там же. С. 40-62.

156 См.: Ростовский И. Правовое просвещение и изба-читальня. М., 1927. 
были организованы курсы подготовки пропагандистов, на которых слушателей знакомили с основными постулатами колхозного строительства ${ }^{157}$.

Масштабность и массовость выборных кампании 1937 1939 гг. на Дальнем Востоке, как и по всей стране потребовала тщательной подготовки. С техническими работниками избирательных комиссий и агитаторами была проведена работа по правовому просвещению. Масштабность возлагаемых на агитаторов задач, главной из которых было разъяснение населению новелл Конституции 1936 г. и нововведений избирательного законодательства, потребовала наличия у них теоретической базы, поэтому на курсы пропагандистов могли быть приняты только члены ВКП (б) с 5-летним стажем, имеющие не менее 2-х лет опыта пропагандистской работы. Все поступающие должны были быть грамотными людьми не моложе 34 лет ${ }^{158}$. Такое требование было необходимым условием, т.к. только специалисты с партийным стажем, прослушавшие не один курс партийного просвещения, знавшие основы советского строительства могли сравнить конституционные нормы и просветить население о сущности преобразований.

Зимой 1938 г. в крупных городах начали действовать образовательные центры, так в феврале в Хабаровске открылась краевая школа пропагандистов. Программа обучения в ней была рассчитана на 1 год и включала не только аудиторную нагрузку, но и практическую пропагандистскую деятельность, что в условиях

${ }^{157}$ ГАХК. Ф. П-2. Оп. 4. Д. 136. Л. 428.

${ }^{158}$ Там же. Оп. 11. Д. 247. Л. 94. 
развертывания предвыборной кампании было весьма кстати. Обучающиеся помимо курса истории изучали политэкономию, основы диалектического и исторического материализма, партийную пропаганду и агитацию, а также нормы Конституции СССР и Конституции РСФСР ${ }^{159}$. Краткосрочные 10-дневные курсы и 3-х и 4-х дневные семинары для 512 агитаторов были проведены в Биробиджане и для 204 агитаторов в Хабаровске, а в целом в Хабаровском крае на таких курсах удалось обучить 4000 чел. Основное внимание курсантов также было уделено изучению конституционных норм и положений избирательного закона ${ }^{160}$. В Завитинском районе Амурской области была организована месячная подготовка 24 агитаторов, аналогичные курсы для 2210 чел. действовали и в Хабаровском крае. В течение апреля 1938 г. слушатели изучали нормы Конституции и положение о выборах в Верховный Совет РСФСР ${ }^{161}$. В Хабаровске была открыта выставка, посвященная этапам становления отечественного избирательного права ${ }^{162}$. Огромная работа было проведена по подготовке сельских агитаторов. С будущими беседчиками был проведен семинар «Выборы в Верховный Совет РСФСР и задачи сельских районов Дальневосточного края в 1938 г.», партийным руководством региона организованы 3 агитационные машины, агитационные коллективы заводов выезжали в колхозы где изучали с колхозниками советское

${ }^{159}$ ГАХК. Ф. П-2. Оп. 11. Д. 247. Л. 93.

${ }^{160}$ Там же. Д. 250. Л. 35-36; Д. 250а. Л. 82; Д. 253. Л. 12.

161 Там же. Л. 1.

162 Там же. Л. 38; Д. 250а. Л. 66-72, 83. 
избирательное законодательство ${ }^{163}$.

Работа пропагандистов и агитаторов не ограничивалась знанием положений о выборах, на курсах изучали решения ЦК ВКП (б) и СНК СССР, касающиеся жителей города и села $^{164}$. К 1940 г. только в Хабаровском крае было подготовлено 9638 агитаторов, а агитационной работой охватывалось свыше 5 млн. чел., однако завершение процедуры выборов советских органов власти привело к сокращению пропаганды законодательства, а основной темой работы с населением стало изучение «Краткого курса ВКП (б)» ${ }^{165}$. Правовое просвещение дальневосточного населения в 1940-1941 гг. касалось законодательства о подоходном налоге, сборов на нужды культурно-бытового строительства населения, о переходе на 7-дневную рабочую неделю и 8-часовой рабочий день и проч. Поэтому именно эти темы становились ключевыми на 10-дневных курсах пропагандистов проведенных во всех районах Дальнего Востока ${ }^{166}$.

${ }^{163}$ ГАХК. Ф. П-2. Оп. 11. Д. 250а. Л. 53-54.

${ }^{164}$ ГАХК. Ф. П-35. Оп. 3. Д. 56. Л. 49-57, 62-63; Д. 91. Л. 4-22.

165 Там же. Д. 93. Л. 1-102; Д. 101. Л. 11-12.

166 Там же. Оп. 1. Д. 559. Л. 53, 161-163. 


\section{ГЛАВА 4. ПРАВОВОЕ ПРОСВЕЩЕНИЕ В СИСТЕМЕ ПРОФЕССИОНАЛЬНОЙ ПОДГОТОВКИ СОТРУДНИКОВ ДАЛЬНЕВОСТОЧНЫХ ГОСУДАРСТВЕННЫХ ОРГАНОВ}

После событий октября 1917 г. в сознание новоиспеченных граждан Советской России стали активно внедряться идеи коммунизма. Отрицание права и его замена революционным правосознанием граждан, не могли не отразиться на принципах правового просвещения, они были переориентированы на усвоение личностью идеалов партии большевиков. В первые годы советской власти правовое просвещение специалистов советских судебных органов было основано на восприятии права как «контрреволюционного» предмета, «отравляющего и дурманящего опиума» ${ }^{167}$. Оно реализовывалось в русле изучения «государственного строя буржуазных стран и Советского общества», знакомства с «Конституцией страны, «организацией Советской власти в центре и на местах», отождествлялось с воспитанием, теоретическим разработкам которого были посвящены работы П.И. Стучки, М.А. Рейснера, Е.Б. Пашуканиса рассматривавших правовое воспитание с классовых позиций. Лишь реализация принципов новой экономической политики потребовавшая расширения гражданско-правовых отношений способствовала пересмотру отношения к праву как чуждому, «буржуазному» регулятору общественных отношений.

167 Гойхбарг А.Г. Основы частного имущественного права. Очерки. М., 1924. С. 8; Иоффе О.С. Развитие цивилистической мысли в СССР. Ч. 1. Л., 1975. С. 39-42. 
Проблема правового просвещения представителей правоохранительных структур оставалась актуальной на всей территории Советской России, важной она была и для Дальневосточной республики. Действовавшее в буфере законодательство, безусловно имело свои особенности, однако формировалось в русле советского права. Решая проблему изучения норм советского права действующими сотрудниками учреждений юстиции, его руководство разработало и направило председателям окружных судов программу проведения занятий. Их цикл состоял из 16 тем затрагивавших изучение основных отраслей советского права. На лекциях освещались положения Конституции РСФСР, законодательство о судоустройстве, вопросы уголовного права и процесса, а также Земельного и Лесного кодекса РСФСР ${ }^{168}$. Основная цель занятий состояла в распространении знаний о советском праве как наиболее прогрессивном. Контроля знаний слушателей не производилось.

Для повышения квалификации кадров работники учреждений дальневосточных органов юстиции направлялись на юридические факультеты и факультеты общественных наук вузов РСФСР ${ }^{169}$. При этом в Законе «О стипендиях для учащихся высших учебных заведений» устанавливалось требование обязательной отработки выпускника на Дальнем Востоке по специальности из расчета «1 год за 1 год пользования стипендией» ${ }^{170}$. Количество целевых направлений было небольшим, но возвращавшиеся выпускники занимали руководящие

${ }^{168}$ ГАХК. Ф. П-2. ОП. 3. Д. 115. Л. 10-13.

${ }^{169}$ РГАСПИ. Ф. 372. Оп. 1. Д. 560. Л.103-108, 275, 281-282, 316.

${ }^{170}$ ГАХК. Ф. Р-18. Оп. 1. Д. 7. Л. 404. 
должности в судебных органах региона. Тем не менее, активная деятельность органов власти Дальневосточной республики по повышению уровня подготовки руководящего состава учреждений юстиции, позволила в начале октября 1922 г. отменить постановления Правительства ДВР о мобилизации юристов ${ }^{171}$. Немногочисленный кадровый корпус руководителей дальневосточного правосудия был пополнен специалистами, обладающими знаниями о праве.

В буфере проводилось правовое просвещение и сотрудников государственного аппарата. Действовали курсы для административных работников, на которых обучающиеся изучали «общие сведения из области права, основные законы ДВР и РСФСР, центральные и местные правительственные установления» ${ }^{172}$. Курсы для этой категории проходили в течение 3-х месяцев и организовывались сотрудниками МВД ДВР.

Освобождением Приморья был положен конец Гражданской войне на Дальнем Востоке. Разгром интервентов и белогвардейцев, создавшаяся благоприятная обстановка позволили осуществить воссоединение региона, где существовала Дальневосточная республика с Советской Россией. Местная партийная организация приступила к формированию органов власти, способных справится с трудностями восстановления народного хозяйства. Борьба с представителями Белого движения, которые находились в эмиграции, разгул бандитизма, откровенно враждебная деятельность представителей эсеро-меньшевистских партий,

${ }^{171}$ ГАХК. Ф. Р-18. Оп. 1. Д. 7. Л. 391.

${ }^{172}$ ГАХК. Ф. Р-19. Оп. 1. Д. 84. Л. 9. 
вызывали необходимость принятия чрезвычайных мер по укреплению Советской власти на Дальнем Востоке. Ключевую роль в этом процессе должна была играть законность. Население региона, уставшее от правового калейдоскопа Гражданской войны, остро нуждалось в установлении правопорядка. Однако корпус специалистов в области юстиции не обладал знанием законодательства РСФСР.

Советское законодательство в 1920-1930-е годы предполагало обязательную юридическую подготовку лишь для занятия некоторых должностей в правоохранительных органах. Из сферы профессиональной деятельности юристов выпадал сегмент должностей государственной службы в которых знания о советском праве были полезны. Руководящий состав дальневосточных Советов, а также председатели исполнительных комитетов не имели юридических знаний, что доставляло немало сложностей в реализации государственных и партийных директив. Строящиеся советские органы власти, после вхождения региона в состав РСФСР, столкнулись с массовым правовым нигилизмом и произволом.

Завершение Гражданской войны позволило привлекать к советской работе демобилизованных военнослужащих. В июне 1925 г. Главполитпросвет, Политическое управление Красной армии, Народный комиссариат просвещения, Народный комиссариат внутренних дел, Народный комиссариат земледелия и Сельскохозяйственный союз договорились об организации 90-часов курсов для военнослужащих, увольняемых в запас. В соответствии с программой курсанты в течение 40 часов изучали 
уголовное и уголовно-процессуальное законодательство, административное право и нормативные документы НКВД, а по выпуску могли работать избачами и милиционерами в сельской местности ${ }^{173}$. Начиная с 1926 г. демобилизованных красноармейцев стали готовить на 100часовых курсах земельников, специалистов по советскому строительству и милиционеров. Программа изучения разнилась, однако правовые дисциплины составляли значительную долю отведенного для обучения времени ${ }^{174}$. Проведенные курсы позволили заполнить в сельской местности вакансии советских служащих. Безусловно качество знаний вчерашних курсантов было невысоким, но демобилизованные военнослужащие понимали важность дисциплины и подчинения указаниям вышестоящего руководства, были готовы реализовывать советские принципы строительства государства.

В 1925 г. исполнявший обязанности прокурора Дальневосточной области Е.Л. Рапопорт в докладе «О революционной законности на Дальнем Востоке», направленном в Дальневосточное бюро ЦК РКП (б), отмечал, что «не только низовой аппарат, но и некоторые руководящие работники партийно-советских учреждений губерний считали вполне допустимым, исходя из соображений т.н. целесообразности, грубейшее нарушение закона» ${ }^{175}$. В докладе приводятся факты расстрела в 1924 г. в Чите морфинистов «без всякого суда

173 ГАРФ. Ф. Р-393. ОП. 51. Д. 29. Л. 120, 126-128,138, 145; Оп. 72. Д. 35. Л. 39-40.

174 Там же. Оп. 72. Д. 35. Л. 41-46, 49-53, 67-71.

175 РГАСПИ. Ф. 372. Оп. 1. Д. 1000. Л. 132-132 об. 
и следствия в целях изъятия», а также расстрел «предполагаемой сифилитички-проститутки», будто бы заразившей красноармейцев сифилисом. Имеются сведения о «вопиющем беззаконии»: вынесении партийной ячейкой в с. Быркинское Борзинского уезда Забайкальской губернии постановления об убийстве 2-х крестьян «как вредного для общества элемента» ${ }^{176}$. Бездействие партийно-советских органов в отношении огласки и расследования описанных фактов объяснялось «специфическими условиями Дальнего Востока», причем «особо ярко это высказывалось в Приморье». Попустительское отношение советского руководства Дальнего Востока к действиям своих сотрудников, а также бездействие правоохранителей негативно сказывалось на восприятии представителей Закона. Население не только не обращалось в судебно-следственные структуры, оно самостоятельно устраивало акты самосуда. Такое отношение формировало общий правопорядок в регионе. Дальневосточный партийный комитет пытаясь повысить правосознание работников советских органов организовывал курсы на которых проводилось и правовое просвещение специалистов. Например, учебный план краевых курсов инструкторов районных исполнительных комитетов, проведенных в Хабаровске в 1927 г., из общего количества 247 аудиторных часов, 40 отводил на правовое просвещение. Курсанты изучали назначение, структуру и порядок деятельности народного суда, обсуждали

176 Там же. 
особенности и возможности прокурорского и административного надзора ${ }^{177}$.

Малочисленность рабочего класса на Дальнем Востоке обусловливала необходимость постоянного притока партийцев из центральных районов РСФСР $^{178}$. Отличительные от среднерусской равнины климатические условия, удаленность региона от столицы, неразвитость инфраструктуры, невысокая заработная плата, не покрывавшая минимальные расходы на проживание, провоцировали массовый отток населения. В стороне не оставались и направленные в регион члены РКП (б). С Дальнего Востока в центральные органы коммунистической партии шли телеграммы, с текстом: «Командированные партийные товарищи бегут» ${ }^{179}$. Все этот накладывало отпечаток на общую партийно-кадровую работу в регионе.

На совещании судебно-прокурорских работников Дальневосточного края, состоявшемся в Хабаровске в октябре 1934 г., представители правоохранительных органов отмечали слабое знание местным руководством ВКП (б) советского законодательства, для чего предлагалось «организовать Отдел судебной политики в ТОЗе» ${ }^{180}$. По мысли собравшихся в местной партийной газете для правового просвещения жителей края необходимо было публиковать приговоры и освещать отдельные юридические вопросы. Однако до практической

${ }^{177}$ ГАХК. Ф. П-2. Оп.11. Д. 42. Л. 121.

${ }^{178}$ РГАСПИ. Ф. 372. ОП. 1. Д. 86. Л. 147.

${ }^{179}$ Там же. Д. 188. Л. 38; ГАХК. Ф. Р-58. Оп. 1. Д. 7. Л. 51.

${ }^{180}$ ГАХК. Ф. П-2. Оп. 1. Д. 559. Л. 13. 
реализации предложений дело не дошло. Сказывалось и отсутствие специалистов, способных подготовить необходимый материал, и общесоветский курс на замену правового просвещения партийным воспитанием.

Реализация практики правового просвещения советских работников стала возможной лишь во второй половине 1930-х гг., т.е. с утверждением государственного курса на распространение правовых знаний. С сентября 1938 г. по январь 1939 г. в Хабаровске осуществлялась курсовая подготовка секретарей районных комитетов ВКП (б). В учебном плане помимо идеологической подготовки слушателям преподавалась дисциплина «Конституция СССР». Лекции читал не профессионал-юрист, а инструктор отдела пропаганды М.П. Ларионов ${ }^{181}$. Таким образом основной задачей являлось не распространение знаний о советском праве, а пропаганда современных задач партийного строительства и мероприятий советской власти.

Советская юстиция, формирование которой происходило на протяжении двух советских десятилетий, все это время пыталась избавиться от специалистов, получивших знания еще до революций 1917 г. Поэтому к середине 1920-х гг. в органах советской юстиции была проведена не одна «чистка» кадров ${ }^{182}$. На места уволенных специалистов, не соответствовавших занимаемой должности по своему классовому происхождению, направлялись представители рабоче-крестьянского актива. С выдвиженцами «оторванными от рабочего станка» не проводили никакой

${ }^{181}$ ГАХК. Ф. П-2. Оп. 6. Д. 691. Л. 107-110, 159.

${ }^{182}$ РГАСПИ. Ф. 372. ОП. 1. Д. 568. Л. 1-38; Д. 583. Л. 4; ГАЗК. Ф. Р27. Оп. 1. Д. 177. Л. 61-64. 
предварительной подготовки ${ }^{183}$. Сотрудники низового аппарата зачастую не имели образования. С впервые назначенными на должности сотрудниками проводили «инструктаж путем осмотра дел на месте и дачи необходимых указаний и разъяснений, чтения лекций, проведения бесед, подготовки письменных указаний по общим вопросам» ${ }^{184}$. На этом их профессиональные знания заканчивались. Отсутствие финансирования затрудняло повышение квалификации уже имеющихся народных судей. Основным источником пополнения кадров служили практиканты и стажеры, направляемые советскими вузами. Говоря «языком» документов и инструкций рассматриваемого периода, следует говорить не о просвещении, а о политико-воспитательной работе. Это связано с тем, что по мнению партийного руководства сотрудники правоохранительных органов должны были быть идейно выдержанными и в своей работе реализовывать партийные директивы. В этой связи идеологическая работа среди масс выступала на первый план. В отличие от центральных регионов РСФСР, где к середине 1920-х гг. роль правовых норм была восстановлена, на Дальнем Востоке еще длительное время правоохранительная деятельность осуществлялась на основе революционного правосознания. Активно развивалась система партийного просвещения.

Идейная подготовка принятых специалистов не означала знания ими советского законодательства. Среди нарушений процессуального права имелись случаи

${ }^{183}$ ГАЗК. Ф. Р-49. Оп. 1. Д. 385. Л. 191.

${ }^{184}$ РГИА ДВ. Ф. Р-2460. Оп. 1. Д. 298. Л. 93. 
вынесения приговоров при отсутствии состава преступления (45,3\%), недостаточной изученности судьей обстоятельств дела $(20,3 \%)$, слабой конкретизации вынесенного приговора, слушания дела в отсутствие обвиняемого, нарушения процедуры вынесения приговора, нарушения порядка назначения мер социальной защиты и амнистии и т.п. ${ }^{185}$. Были недостатки и при ведении гражданского судопроизводства. Например, присуждались алименты до рождения ребенка, прекращались дела в связи со смертью истцов, которая документально не подтверждалась ${ }^{186}$. Понимание последствий вынесенных решений приходит с осознанием того, что за каждым из них стоят человеческие судьбы. Неверно вынесенное судебное решение, порой, кардинально меняет человеческую жизнь.

Во второй половине 1920-х гг. квалификация дальневосточных судебных работников оставалась низкой. Принимаемые на службу сотрудники, сталкиваясь с огромным объемом работы и низкой оплатой труда, «в течение очень небольшого времени уходили, чтобы уступить место другим товарищам, знавшим службу еще меньше» ${ }^{187}$. С 20 по 24 марта 1925 г. в Хабаровске прошло первое Областное совещание прокуроров губернии и председателей губернских судов. В резолютивной части отмечалось, что необходимо изжить «административный

185 ГАЗК. Ф. Р-49. Оп. 1. Д. 988. Л. 11-119, 133-135, 146-147, 156159; Ф. Р-55. ОП. 1. Д. 45. Л. 35-39.

${ }^{186}$ ГАЗК. Ф. Р-49. Оп. 1. Д. 988. Л. 134.

${ }^{187}$ РГИА ДВ. Ф. Р-2460. Оп. 1. Д. 149. Л. 278. 
произвол и приступить к применению норм права» ${ }^{188}$. Участниками совещания подчеркивалась необходимость увеличения количества часов курсовой, лекционной и кружковой работы среди сотрудников органов рабочекрестьянской милиции и органов юстиции, а также обращения внимания на обновление юридической литературы и проведение правового просвещения. В 1929 г. реализуя поставленные центральными органами юстиции задачи, дальневосточные юристы организовали при краевом суде курсы подготовки низового профсоюзного актива ${ }^{189}$. Их работа была признана удовлетворительной. Выпускники направлены в профсоюзные организации для решения конфликтных ситуаций.

Способом повышения квалификации судебных работников края явились стажировки и практики. Согласно постановлениям СНК СССР от 14 июня 1926 г. и СНК РСФСР от 27 сентября 1926 г., все органы юстиции были обязаны предоставлять места платной практики студентам, a также должности для стажировок выпускникам советских высших учебных заведений ${ }^{190}$. После завершения практики или стажировки учреждения органов юстиции предоставляли в вуз сведения о результатах работы выпускников, сложности выполняемых обязанностей, недостатках подготовки направляемых специалистов.

188 РГАСПИ. Ф. 372.ОП. 1. Д. 294. Л. 13; ГАХК. Ф. Р-1962. Оп. 1. Д. 13. Л. 10-11.

${ }^{189}$ ГАХК. Ф. П-2. Оп. 3. Д. 200. Л. 14-15.

${ }^{190}$ ГАЗК. Ф. Р-49. Оп. 1. Д. 385. Л. 138; Д. 988. Л. 10. 
Интересной формой правового просвещения являлось изучение местных средств массовой информации. Например, камчатская газета «Полярная звезда» во второй половине 1920-х годов на своих полосах имела «Пролетарский раздел», в котором регулярно публиковались законодательные новеллы, печатались ответы на вопросы читателей из области права, освещались наиболее одиозные уголовные дела и раскрывались результаты работы камчатских милиционеров.

Для студентов, получавших юридическое образование заочно, издавался методический и инструктивноинформационный бюллетень «Заочник-юрист» ${ }^{191}$. На его страницах преподаватели образовательных учреждений рекомендовали методы самостоятельной работы по изучению правовых дисциплин, описывали новеллы законодательства по различным отраслям, обращали внимание на наиболее частые ошибки в устных выступлениях студентов в период сессий, отвечали на вопросы читателей.

В сентябре - декабре 1929 г. по решению агитационнопропагандистского отдела Дальневосточного краевого комитета ВКП (б) «Тихоокеанская звезда» провела смотрконкурс учреждений юстиции Дальневосточного края. Его целями являлись выявление гражданами недостатков в работе суда и милиции, популяризация советского законодательства, борьба с бюрократизмом и волокитой. Газета на своих полосах освещала работу судебных учреждений края, публиковала отзывы граждан о работе

191 Заочник-юрист. Методический и инструктивно-информационный бюллетень. 1929. № 1-4. 
органов юстиции, обращала внимание на уровень подготовки кадров ${ }^{192}$. Интерес общественности сыграл положительную роль. Итоги смотра подводились не только в органах юстиции, но и на партийных собраниях. В некоторых выступлениях партийных работников были сделаны выводы в духе социалистического релятивизма. Например, представитель окружного комитета ВКП (б) Киселев, выступавший с докладом на окружном съезде работников юстиции Читинского округа в январе 1929 г., рассуждая о подготовке работников суда, сказал: «Сегодня, когда дело идет в сторону раскрепощения судебного работника от паутины формальных требований, колоссально возрастает его ответственность. Нельзя будет разбирать дело придерживаясь только буквы закона. Поэтому наша задача готовить кадр стойких честных работников с классовой установкой».В этой связи показателен пример увольнения судьи в ПетровскЗабайкальском народном суде. Судья, рассматривая уголовное дело, заявил «перед судом все равны» и вынес оправдательный приговор. Его действия окружным судом были названы «художествами», а судью, как «не использовавшего классовый подход», сняли с должности ${ }^{193}$.

В целом, в 1920-х гг. сохранялось слабое финансирование дальневосточной системы правового просвещения, что не позволяло осуществлять мероприятия в динамике. Краткосрочные курсы, организуемые в районах Дальневосточного края, носили эпизодический

${ }^{192}$ ГАХК. Ф. П-2. Оп. 9. Д. 200. Л. 73; Оп. 11. Д. 92. Л. 10; Д. 119. Л. 1. Тихоокеанская звезда. 1928. 13 нояб.; 28 нояб.

${ }^{193}$ ГАЗК. Ф. Р-49. ОП. 1. Д. 385. Л. 189-190. 
характер. Еженедельные занятия проводились при Амурской и Приморской областных прокуратурах. Юридические кружки, в т.ч. и при Камчатской прокуратуре, народных судах края существовали номинально, областные совещания судебных работников носили случайный характер и проводились без плана и программ ${ }^{194}$. Они не оказывали существенного влияния на качество знаний специалистов суда и следствия, т.к. на них сообщались лишь общие установки, после чего у посещавших курсантов складывалось мозаичное представление о советской правовой системе. Советского правового мировоззрения сформировать не удавалось.

С пересмотром в начале 1930-х гг. государственного подхода к юридическому образованию и правовому просвещению в Дальневосточном регионе работа в этом направлении ожила. Центром были выделены денежные средства для организации курсов подготовки и переподготовки, однако выделенных денег на организацию постоянно действующего стационарного образовательного учреждения было недостаточно, отсутствовали и педагогические кадры. На проходившем в октябре 1934 г. совещании юридических работников Дальневосточного края отмечалось, что для организации юридических курсов требовалось «по скромным подсчетам около 4,5 тыс. руб.» ${ }^{195}$, таких денег у региона не было. Да и загруженность судей была огромной. В

194 РГИА ДВ. Ф. Р-2460. Оп. 1. Д. 149. Л. 218; Д. 298. Л. 94-95; ГАЗК. Ф. Р-49. Оп. 1. Д. 345. Л. 38; Д. 367. Л. 1-12, 15-25; Д. 988. Л. 89-90; ГАХК. Ф. П-2. ОП. 3.Д. 115. Л. 30, 33-35; Д. 200. Л. 36.

${ }^{195}$ ГАХК. Ф. П-2. Оп. 1. Д. 559. Л. 8-10. 
городском суде Хабаровска в производстве судьи имелось около 500 дел. В таких условиях даже временный отрыв от работы негативно сказывался на состоянии судопроизводства в краевом центре. Кроме того, судебное учреждение не имело своего помещения, оно размещалось только в одной комнате.

Слабое финансирование системы школьной и курсовой юридической подготовки вынуждало местное руководство юстиции прибегать к проведению внешкольных занятий. Приказом прокурора СССР от 1 октября 1934 г. были установлены обязательное изучение и сдача юридического минимума всеми сотрудниками суда и прокуратуры, не имевшими высшего юридического образования. Вопросы минимума, в основном, касались практической деятельности. Для повышения качества подготовки прокурорских работников были изданы учебные пособия ${ }^{196}$. Однакорасширение общественной нагрузки (выступление с докладами на предприятиях с пропагандой советского права, общественно-правовая работа в деревне, просветительская работа среди военнослужащих) ${ }^{197}$ приводило к снижению качества работы и кадровой текучке.

Пересмотр государственной политики в сфере юридического образования и правового просвещения способствовали увеличению финансирования этих направлений работы правоохранительных органов. Начиная со второй половины 1930-х гг., на местах

196 Строгович М. О юрминимуме и юридической грамотности // Социалистическая законность. 1936. № 2. С. 67-68.

${ }^{197}$ ГАХК. Ф. Р-819. Оп. 2. Д. 5. Л. 89; Постановление Агитационнопропагандистского бюро ЦК ВКП (б) о популяризации советского законодательства // Еженедельник советской юстиции. 1927. 28 апр. 
увеличилось количество сотрудников, направляемых для повышения квалификации в образовательные учреждения не только Сибири и Дальнего Востока, но и центральных регионов страны. Периодически проводились проверки знания советского законодательства, где представители юстиции иногда показывали неудовлетворительные результаты. С целью устранения пробелов, московское руководство настаивало на проведении дополнительных внеплановых занятиях по изучению советского законодательства ${ }^{198}$.

В Амурской области с лета 1938 г. действовал юридический кружок для следственно-прокурорских работников. На еженедельных занятиях рассматривались статьи Конституции РСФСР, изучались темы по уголовному и гражданскому праву, особенности ведения уголовного и гражданского процессов ${ }^{199}$. Таким образом к концу 1930-х гг. в Дальневосточном регионе постепенно формировалась система профессиональной подготовки специалистов органов юстиции.

Правовое просвещение - важнейшее направление в становлении правопорядка в обществе. Советская юридическая наука до середины 1920-х гг. негативно трактовала дореволюционные подходы к пониманию сущности права, а, следовательно, и разрабатывала новую концепцию правового воспитания, в основе которой лежали идеи коммунизма. Так как частью правового воспитания является правосознание, пришедшие к власти большевики полагали, что революционное правосознание

${ }^{198}$ ГАХК. Ф. Р-384. Оп. 8. Д. 5. Л. 206-207; Д. 43. Л. 2.

${ }^{199}$ РГИА ДВ. Ф. Р-3190. Оп. 1. Д. 1110. Л. 1. 
присуще всем представителям пролетариата и крестьянства. Такой подход способствовал распространению самосуда, расправ, актов произвола.

Признание важности права и необходимости правового образования на государственном уровне, произошедшее в середине 1930-х гг., способствовало содержательному наполнению правового воспитания как комплекса мероприятий, направленных на усвоение личностью существующих правовых норм. Однако в Дальневосточном регионе правовое просвещение не имело системного характера. Утвержденные центральным московским руководством планы проведения внешкольных занятий на Дальнем Востоке сопрягались с многочисленными сложностями.

Мероприятия по правовому просвещению проводились периодически в южных районах Дальнего Востока, а в труднодоступных северных - эпизодично. Главными причинами являлись большая профессиональная нагрузка правоохранителей, отсутствие актуальной литературы, недостаток выделяемых денежных средств и нехватка профессиональных преподавателей юридических дисциплин. 


\section{ГЛАВА 5. ФОРМИРОВАНИЕ ПРАВОВОЙ КУЛЬТУРЫ ДАЛЬНЕВОСТОЧНЫХ МИЛИЦИОНЕРОВ}

Образованная осенью 1918 г. Рабоче-Крестьянская милиция, по мнению руководителей Советской России мыслилась как орган защиты интересов рабочих и крестьян, охраны революционного порядка и безопасности. Начало Гражданской войны потребовало дополнить этот подход пониманием деятельности милиционеров в качестве «вооруженного отряда диктатуры пролетариата». Поэтому основными критериями приема на службу являлись не образовательный уровень и служебный опыт, а партийная принадлежность и следование «идеалам революции». Террор в отношении политических противников считался оправданным и уголовно не преследовался. В условиях краха не только законодательной, но и судебной систем, правосудие, зачастую, осуществлялось «по законам военного времени».

На Дальнем Востоке, где Гражданская война и военная интервенция носили более продолжительный характер, деятельность милиции обладала своими особенностями. Дальневосточная республика имела свою общереспубликанскую милицию, возглавляемую с 24 ноября 1920 г. Главным управлением милиции ДВР. Ее структура и принципы деятельности копировались с милиции Советской России. Согласно «Временному положению о народной милиции ДВР» права и обязанности милиционеров, их задачи не были четко 
регламентированы, а требования, предъявляемые к кандидатам на службу, отсутствовали. Формирование кадрового состава милиционеров не предусматривало прохождения проверки на связь с преступным элементом, изучение мотивации поступления на службу и т.п. Лишь с вступлением в силу в сентябре 1921 г. «Закона о милиции» был введен принцип грамотности для принимаемых сотрудников. Милиционеры должны были вызывать у населения доверие, а поэтому от поступающих на службу требовалось умение читать и писать. Но выполнение этих требований осложнялось огромным числом неграмотных жителей региона. Знания законодательства от претендентов на службу не требовалось. В соответствии с общим характером политики дальневосточной просоветской власти основой правоохранительной деятельности должно было быть революционное правосознание. Такие специфичные по современным меркам подходы к комплектованию органов милиции приводили к тому, что общая кадровая ситуация в милиции буфера была сложной.

Руководящий состав уездных и городских милиций помимо личных качеств, высокой грамотности, образовательного ценза и доверия общественности, должен был иметь рекомендацию областных, уездных или городских комитетов РКП (б $)^{200}$. Это были очень высокие требования, но даже несмотря на это квалификация руководящего состава оставляла желать лучшего. Так, заведующему милицией Благовещенска Дмитриеву «за

${ }^{200}$ ГАХК. Ф. Р-864. Оп. 1. Д. 8. Л. 23-24; Собрание узаконений и распоряжений правительства ДВР. 1921. № 5. (11). 
безграмотное, трудно понимаемое составление приказов и инструкций» был объявлен выговор ${ }^{201}$. Законодательством республики была определена система мер по повышению уровня профессиональной подготовки сотрудников милиции ${ }^{202}$ и в дополнение закона о милиции издавались циркуляры, регламентировавшие деятельность ее руководства ${ }^{203}$, но с начальствующим составом никаких занятий не проводилось.

Низовой милицейский аппарат, не прошедший обучение в образовательных учреждениях правоохранительной системы, не имел представления о праве как регуляторе общественных отношений, а в условиях материальной необеспеченности и сам не редко становился преступным элементом. Необходимо отметить, что материальное довольствие милиции было слабым. Обмундированием дальневосточные сотрудники обеспечивались лишь на $70 \%$, а зимний комплект и вовсе не выдавался ${ }^{204}$. Властным органам буферной республики с мест поступала информация о превышении милиционерами должностных полномочий. Так, в документах обращено внимание, что «в районе Старочитинского тракта деятельность милиционеров зависела от зажиточных крестьян» ${ }^{205}$, которые в глухих деревнях могли не накормить и не пустить переночевать командированных милиционеров. Констатировалось

${ }^{201}$ РГИА ДВ. Ф. Р-1007. Оп. 1. Д. 9. Л. 90.

202 Собрание узаконений и распоряжение Правительства ДВР. 1921. № 2(6). C. 10-17.

${ }^{203}$ ГАХК. Ф. Р-18. Оп. 1. Д 5. Л. 4 об.

${ }^{204}$ ГАРФ. Ф. Р-393. Оп. 48. Д. 70. Л. 5; Д. 72. Л. 3.

${ }^{205}$ ГАХК. Ф. Р-925. Оп. 1. Д. 1. Л. 56-68, 216. 
нищенское существование сотрудников милиции, которое вынуждало их злоупотреблять властью. Анализируя итоги работы Прибайкальской милиции в 1921 г., ее командование, отмечало что «кадр больше занят изысканием средств на пропитание, чем исполнением своих непосредственных обязанностей» ${ }^{206}$. Глава милиции Читы докладывал, что «милиционеры массово ходатайствуют о предоставлении отпусков от 10 до 30 суток для поездки за продуктами, паек они не получают. Занимаются попрошайничеством среди граждан или торговцев» ${ }^{207}$. Руководитель просил «удовлетворить милиционеров всем необходимым», считал невозможным предъявлять к ним требования о несении службы, понимая, что имеющиеся кадры могли уйти в армию, где пайковым довольствием обеспечивались исправно. В уездных милициях неоднократно фиксировались случаи перехода в военное ведомство «наиболее способных работников даже по вольному найму» ${ }^{208}$. В Петрово-Заводской милиции за преступления, связанные с исполнением служебных обязанностей, только в июле 1922 г. было уволено 7 милиционеров. Милиционеры из Троицкосавска, Красного Яра (Прибайкалье), Хабаровска, Владивостока привлекались за взятки ${ }^{209}$. В информационных сводках МВД ДВР за 1921-1922 гг. свидетельствовалось бедственное положение милиционеров: невыплата

${ }^{206}$ РГАСПИ. Ф. 372. ОП. 1. Д. 1192. Л. 4-5.

${ }^{207}$ ГАЗК.Ф. Р-402. Оп. 1. Д. 17. Л. 85-86.

${ }^{208}$ РГИА ДВ. Ф. Р-1007. Оп. 1. Д. 9. Л. 47; ГАЗК. Ф. Р-402. Оп. 1. Д. 17. Л. 86.

${ }^{209}$ ГАХК. Ф. П-44. Оп. 1. Д. 279. Л. 125; Ф. Р-1025. Оп. 1. Д. 2. Л. 6. 
жалования, недоверие населения и разгул бандитизма ${ }^{210}$. Летом 1922 г. сотрудники Государственной политической охраны ДВР провели анализ работы прибайкальских милиционеров. В их отчетном докладе указано, что «качественный состав ниже всякой критики, милиционеры в большинстве малоразвиты, несознательны и в большей своей части из элемента случайного, нередко с уголовным прошлым ${ }^{211}$. В августе 1922 г. в Чите проходило собрание сотрудников милиции города, на котором обсуждались проблемы денежного довольствия. Собравшиеся были недовольны задержками выплат денежного довольствия, которые составляли до 2-х месяцев ${ }^{212}$. Недостаток финансирования вынуждал руководство милиции буфера искать неординарные решения. В октябре 1922 г. начальник милиции буфера через средства массовой информации обратился к населению $\mathrm{c}$ просьбой безвозмездно предоставить постовые тулупы, катанки, полушубки, папахи, простыни, одеяла и полотенца ${ }^{213}$. Однако его просьба осталась неуслышанной, на первый план в этот период выходили задачи завершения гражданской войны и интервенции в регионе.

Нарушения касались и служебных отношений. Начальник хабаровской городской милиции отмечал, что «сотрудники, докладывая руководству, не отдают рапорт», «уходят с поста ранее установленного времени», нарушают форму одежды «не носят нарукавных

\footnotetext{
${ }^{210}$ ГАХК. Ф. Р-925. Оп. 1. Д. 1. Л. 68.

211 Там же. Ф. П-44. Оп. 1. Д. 279. Л. 133.

212 Дальневосточный путь. 1922. 13 авг.

213 Там же. 26 июля.
} 
нашивок», «не умеют составлять протоколы», «грубо общаются с задержанными», один из сотрудников и вовсе был уволен с формулировкой «ищущий не работы, а тепленького местечка» ${ }^{214}$. Руководитель в своих приказах отмечал, что такое поведение милиционеров «подчеркивает разнузданность, недисциплинированность и отсутствие элементарных понятий о службе» ${ }^{215}$.

Руководящий состав уездных и городских милиций помимо личных качеств, высокой грамотности, образовательного ценза и доверия общественности, должен был иметь рекомендацию областных, уездных или городских комитетов РКП (б) ${ }^{216}$. Это были очень высокие требования, но квалификация руководящего состава оставляла желать лучшего. Так, заведующему милицией Благовещенска Дмитриеву «за безграмотное, трудно понимаемое составление приказов и инструкций» был объявлен выговор ${ }^{217}$. Законодательством республики была определена система мер по повышению уровня профессиональной подготовки сотрудников милиции ${ }^{218}$ и в дополнение закона о милиции издавались циркуляры, регламентировавшие деятельность ее руководства ${ }^{219}$, но с начальствующим составом никаких занятий не проводилось.

${ }^{214}$ ГАХК. Ф. Р-864. Оп .1. Д. 1. Л. 5, 45, 75, 113, 156-157, 196, 199, 206, 216, 232, 237; Ф. Р-1025. Оп. 1. Д. 2. Л. 22.

${ }^{215}$ ГАХК. Ф. Р-864. Оп. 1. Д. 1. Л. 237.

${ }^{216}$ ГАХК. Ф. Р-864. Оп. 1. Д. 8. Л. 23-24; Собрание узаконений и распоряжений правительства ДВР. 1921. № 5. (11).

${ }^{217}$ РГИА ДВ. Ф. Р-1007. Оп. 1. Д. 9. Л. 90.

218 Собрание узаконений и распоряжение Правительства ДВР. 1921. № 2(6). C. 10-17.

${ }^{219}$ ГАХК. Ф. Р-18. Оп. 1. Д. 5. Л. 4 об. 
Сложное внешне-и внутриполитическое положение буферной республики не позволяло решить финансовые затруднения милиционеров. Основным способом борьбы с нарушениями стал пересмотр кадрового состава. Однако он не имел положительного результата. Образовавшиеся вакансии замещались по призыву партии. По мнению дальневосточного милицейского начальства примером для беспартийных сотрудников должны были стать призванные на службу члены РКП (б). Комитеты коммунистической партии направляли кадры комсомольцев и членов партии на службу в милицию для поднятия политико-морального уровня ее сотрудников. Руководство народной милицией ДВР в своих докладах в партийные органы подчеркивало, что реализуя установку на «выбрасывание полицейщины и привлечение в милицию почти неграмотного населения» 220 , которое фактически ничего общего не имело с милицией, оно сталкивалось с проблемами обучения и инструктирования призванных сотрудников. Люди, приходившие на службу в милицию попросту не знали нормы служебных уставов, не были знакомы с правилами служебного этикета, а о знании ими правовых норм, действовавших в ДВР и вовсе не могло быть речи. Как отмечалось в докладе о состоянии Приморской милиции, направляемые были «в большинстве малограмотные, не служившие в милиции и не желающие служить» ${ }^{221}$. В ноябре 1922 г. начальник дальневосточной милиции докладывал в Дальневосточное бюро ЦК РКП (б), что «жалование платят не на 100\%, поэтому командированные

${ }^{220}$ ГАХК. Ф. Р-925. Оп. 1. Д. 1. Л. 68.

${ }^{221}$ ГАРФ. Ф. Р-393. Оп. 43а. Д. 1104. Л. 1-8. 
партийные товарищи бегут» ${ }^{222}$. Общая картина милицейских кадров была неудовлетворительной, но даже при таких показателях сотрудникам милиции удавалось сдерживать преступность.

Незначительное количество мест в образовательных учреждениях милиции буфера приводило к тому, что основным методом профессиональной подготовки дальневосточных милиционеров стало инструктирование. Только в 1921 г. милицейское руководство буфера направило в низовые учреждения 38 инструкций по различным направлениям деятельности. Например, «Об обязанностях милиционера и волостного надзирателя», «О порядке несения постовой службы в городах», «Обязанности начальника участка», «Правила организации уголовно-розыскных отделений и методы сыска» и др. $^{223}$. В этот период инструктирование являлось наиболее широко распространенным способом подготовки работников для практической деятельности. Конечно, оно не заменяло профессиональные знания, но в специфических условиях гражданской войны оно было чуть ли не единственным способом подготовки сотрудников к профессиональной деятельности.

Первоначально инструктирование проводилось специалистами Главного управления милиции ДВР, а после его преобразования осенью 1921 г. - главными правительственными и областными инспекторами. В соответствии с принятым в сентябре 1921 г. законом «О милиции» в структуре Управления народной милиции ДВР еще в апреле 1921 г. был образован инспекторский отдел, а в областях - инструкторско-ревизионные отделы,

222 РГАСПИ. Ф. 372. ОП. 1. Д. 188. Л. 38.

${ }^{223}$ ГАХК. Ф. Р-18. Оп. 1. Д. 8. Л. 200. 
на которые возлагались функции подбора и подготовки кадров для работы в милиции буфера.

Инструктирование проводилось инструкторскоинформационным отделением, штат которого составлял 5 инструкторов, и инструкторским отделением со штатом инструкторов - 3 чел. ${ }^{224}$. Первые готовили инструкции и занимались их рассылкой на места, а состав вторых был набран из небольшого числа опытных инструкторов приверженцев идей советской власти. Разъезжая по областям они учили, инструктировали командный состав, рядовых, правильно ставили делопроизводство, имели право отстранять от должности сотрудников милиции, не усвоивших инструктаж ${ }^{225}$. С сентября 1921 г. эти функции перешли Главным правительственным и областным инспекторами. Для проверки знаний и инструктирования милиционеров организовывались особые Комиссии при Управлениях уездных милиций ${ }^{226}$, занимавшиеся организацией занятий с наиболее слабыми сотрудниками.

Во всей Дальневосточной республике имелось 16 инспекторов-инструкторов, возрастом от 21 до 25 лет, средним образованием (специального юридического не было ни у кого) и почти все были направлены в отдел из партийных и профсоюзных органов ${ }^{227}$. Инструкторов постоянно не хватало. Как отмечал в августе 1921 г. начальник областной милиции Забайкалья в инспекторско-

${ }^{224}$ ГАЗК. Ф. Р-402. Оп. 2. Д. 18. Л. 46, 49.

${ }^{225}$ ГАРФ. Ф. Р-393. ОП. 44. Д. 19. Л. 875; РГАСПИ. Ф. 372. ОП. 1. Д. 188. Л. 23; Д 401. Л. 5; ГАЗК. Ф. Р-124. ОП. 1. Д. 45. Л. 138; ГАХК. Ф. Р-925. ОП. 1. Д. 1. Л. 68.

${ }^{226}$ ГАЗК. Ф. Р-124. Оп. 1. Д. 45. Л. 138.

227 Там же. Ф. Р-15. Оп. 2. Д. 9. Л. 1-37. 
инструкторском отделе Забайкальской области «недостает сотрудников ввиду плохой оплаты труда, не имеются средства для командировок» ${ }^{228}$. Таким образом, милицейское руководство скорее видело в инструктировании не способ привития профессиональных юридических знаний, а распространение на правоохранителей марксистского мировоззрения.

Ликвидация буферной Дальневосточной республики и вхождение региона в состав Советской России, поставили перед руководством сформированного Дальневосточного революционного комитета задачи по реорганизации органов правопорядка в соответствии с советской вертикалью власти и законодательством. В ноябре 1922 г. ВЦИК РСФСР издал декрет «О пересмотре и доукомплектовании личного состава милиции» ${ }^{229}$. В соответствии с ним руководство регионов должно было в кратчайшие сроки создавать межведомственные комиссии. В их состав входили представители НКВД, Наркомтруда, Наркомата юстиции, ВЦСПС, партийных и профсоюзных организаций. Увольнению из рядов подлежали сотрудники, нарушавшие революционную законность и не годные к службе по социально-классовой сущности. В конце декабря 1922 г. Дальневосточный революционный комитет издал постановление о пересмотре штатов областной милиции. Для чего при губернских исполнительных комитетах были созданы комиссии. В круг их обязанностей входили организация и проведение проверок милицейского аппарата в январе-феврале 1923 г.

${ }^{228}$ ГАЗК. Ф. Р-402. Оп. 1. Д. 22. Л. 20 об.

${ }^{229}$ Собрание узаконений РСФСР. 1922. № 78. ст. 982. 
Отдел управления Дальневосточного революционного комитета своим циркуляром указал, что при проведении пересмотра штатов личного состава милиции целесообразно учитывать мнение трудящихся. Поэтому было рекомендовано проводить публичные заседания комиссий, на открытых собраниях милицейских работников ${ }^{230}$. Реализация данных правовых документов повлекла в милицейской среде массовые увольнения. Сотрудники, имевшие опыт несения службы в милиции, но не годные по классовым соображениям - увольнялись, не дожидаясь «чистки» кадров. Учитывая партийный плюрализм, процветавший в буферной республике, некоторые милиционеры уходили по идеологическим соображениям. В этом контексте показательна формулировка приказа начальника милиции Приамурской губернии, в котором утверждалось, что против тех милиционеров, «у коих нет сознательного отношения к своим гражданским обязанностям, применять меры судебного преследования, как против лиц, недостойных занять подобающее место в истории Великой РабочеКрестьянской революции» ${ }^{231}$.

В рассматриваемый период помимо инструктирования, одним из способов просвещения стала клубная работа. Клубы открывались не только при образовательных учреждениях, но также при уездных и губернских отделах милиции. Клубная сеть была включена в структуру Главполитпросвета. В соответствие с приказами Народного комиссариата просвещения в клубах велась

${ }^{230}$ ГАЗК. Ф. Р-194. Оп.1. Д. 160. Л. 1-383.

${ }^{231}$ ГАХК. Ф. Р-1025. Оп. 1. Д. 2. Л. 12. 
живая газета отражавшая положительные примеры и проблемные стороны работы милиции, проводились вечера вопросов и ответов не только по бытовым вопросам, но и по вопросам административной работы, организовывалось чтение газет, журналов и их обсуждение, осуществлялись коллективные выходы на выставки и экскурсии, устраивались публичные лекции связанные с новеллами законодательства. В свободное от службы время в клубах проводили концерты и гулянья, ставили спектакли. В период агитационных кампаний сотрудники клубов устраивали митинги, занимались пропагандой законодательства о выборах 232 .

Вхождение Дальнего Востока в правовое поле РСФСР обусловило реализацию «Инструкции Главмилиции НКВД РСФСР» утвержденной еще в июне 1921 г. постановлением ВЦИК. В работу с личным составом была введена партийно-политическая составляющая. Профессиональная подготовка кадров без отрыва от работы была заменена политическим воспитанием. При губернских управлениях создавались политические сектора, на которые возлагались задачи организации и проведения воспитательной работы в «коммунистическом духе» $^{233}$ среди милиционеров на основе партийных установок ЦК РКП (б). Комплектование кадров происходило после резолюции начальника городского или уездного управления милиции о соответствии кандидатуры требованиям к уровню общей и военной подготовки, политической благонадежностью. Каждый

${ }^{232}$ ГАРФ. Ф. Р-393. Оп. 23а. Д. 379. Л. 2-11.

233 Там же. Д. 450. Л. 13-14. 
претендент на занятие должности сотрудника милиции заполнял анкету или учетную карточку, отражавшую различные аспекты его биографии. В этой связи перед милицейским начальством, занимавшимся подбором кадров, возникала дилемма: с одной стороны комплектование кадров квалифицированными сотрудниками, с другой - лояльными к советской власти. Совместить оба этих критерия удавалось не всегда. Уже в июле 1923 г. в целях экономии бюджетных средств политические секретариаты были ликвидированы. Их функции передавались комитетам партии губерний, которые выделяли по одному сотруднику для организации воспитательной работы в милиции и уголовном розыске. Инструкторы регулярно отчитывались перед губернскими комитетами партии, а копии отчетов направляли в политическую инспекцию ЦАУ НКВД 234.

К середине 1920-х гг. одной из «болевых точек» оставалась грамотность сотрудников органов милиции. Проведение общероссийской кампании по ликвидации неграмотности, поддержали коммунисты на V Дальневосточной конференции РКП (б). Помимо общей неграмотности предстояло ликвидировать еще и правовую безграмотность. Управление милиции РСФСР внутренними приказами (МР № 186-23 г., MP № $204-23$ г., MP № 65, 67 - 23 г. и № 152- 23 г.) $)^{235}$ ввело внешкольные занятия с командным составом и милиционерами установило минимум знаний для поступления на службу и приняло меры к ликвидации правовой безграмотности.

${ }^{234}$ ГАРФ. Ф. Р-393. ОП. 51. Д. 24. Л. 1.

235 Там же. Оп. 44. Д. 20. Л. 5 об. 
С 1923 г. дальневосточные партийные организации развернули в органах милиции работу под лозунгом «Ликвидируем милицейскую безграмотность». Она основывалась на положениях циркуляра НКВД РСФСР «О проведении среди населения твердых основ революционной законности и ликвидации правовой безграмотности». Во всех территориальных управлениях и городских отделах милиции формировались группы для внешкольных занятий. В марте 1923 г. Дальневосточный революционный комитет утвердил распоряжение «О привлечении неграмотных и малограмотных милиционеров старше 30 лет в школу для обучения». В целях повышения политической и правовой грамотности с сотрудниками, призванными на службу в органы милиции руководством подразделений четыре раза в неделю в течение 20 недель проводились вечерние занятия, освещающие политический курс партии и советского правительства. Разработанный центральным милицейским руководством типовой учебный план включал в себя общеобразовательные предметы в количестве 72 часов, 92 часа отводилось для изучения правовых дисциплин, а на знакомство с административным правом и милицейскими предметами - 112 часов $^{236}$. На занятиях изучались основы Конституции РСФСР, положения теории государства и права, советские нормы гражданского права, уголовного права и процесса, основы трудовых взаимоотношений. Кроме того, согласно приказу Центрального административного управления (ЦАУ) НКВД в занятия была

${ }^{236}$ ГАРФ. Ф. Р-393. Оп. 51. Д. 150. Л. 26; Оп. 65. Д. 86. Л. 1-86; РГИА ДВ. Ф. Р-2422. Оп. 1. Д. 899. Л. 28; Д. 1406. Л. 70. 
включена подготовка по уголовному праву и процессу, судебной медицине, строевой подготовке.

К концу 1924 г. во всех управлениях милиции Дальневосточной области были завершены занятия с личным составом, однако охватить удалось лишь треть сотрудников $^{237}$. Дальневосточный революционный комитет подводя итоги внешкольной работы среди сотрудников рабоче-крестьянской милиции ДВО, подчеркивал, что «занятия в управлениях милиции случайные, бессистемные и заключаются в инструктаже подчиненных соответствующим начальником по вопросам текущей работы без разъяснения полученных приказов, инструкций и т.п. ${ }^{238}$. Объем преподаваемых дисциплин был крайне незначителен, да и посещаемость курсов была нестабильной, т.к. обучение проводилось без отрыва от основной деятельности. Поэтому их эффективность была невысокой. В отделах милиции с большой территорией обслуживания занятия не проводились, а милиционеры переводились «на самообучение с контролем результата» $^{239}$, но из-за отсутствия необходимой литературы самообучение становилось невозможным.

При управлениях уездных милиций организовывались групповые занятия с наиболее слабыми сотрудниками. В отдаленных районах Дальнего Востока работали передвижные школы, активно развивалось самообразование. В качестве преподавателей привлекали «опытный старший командный состав и представителей

${ }^{237}$ ГАРФ. Ф. Р-393. Оп. 51. Д. 150. Л. 62.

${ }^{238}$ ГАЗК. Ф. Р-27. ОП. 1. Д. 128. Л. 21.

${ }^{239}$ ГАРФ. Ф. Р-393. Оп. 51. Д. 150. Л. 62. 
судебных органов» ${ }^{240}$. С сентября 1923 г. всех начальников милиции и уголовного розыска обязали «внушить подчиненным необходимость самообразования и организовать проверки знаний» не желающие учиться подлежали увольнению ${ }^{241}$. Повсеместно организовывались лектории на юридические темы, обязательные для всех сотрудников милиции ${ }^{242}$. Однако, руководство милиции отмечало, что в уездах внешкольная подготовка затруднена, в связи с отсутствием квалифицированных преподавателей и разбросанностью штата ${ }^{243}$. Несмотря на предпринимаемые руководством милиции и партийными структурами усилия, правовые знания милиционеров оставались невысокими. Сказывалась общая загруженность рядовых милиционеров, отсутствие специальной литературы и просто нежелание повышать свою квалификацию.

Особе место отводилось самообразованию милиционеров. Как вспоминал бывший руководитель милиции ПетропавловскКамчатского Петров Василий Васильевич: «в Хабаровске, в ожидании начала судоходства по Охотскому морю в Петропавловск, я около месяца не вылазил из читального зала городской библиотеки, штудируя римское право. В моем представлении - быть начальником милиции и не знать юриспруденции как-то не укладывалось в сознании» ${ }^{244}$. Однако

${ }^{240}$ ГАЗК. Ф. Р-124. Оп. 1. Д. 45. Л. 85.

${ }^{241}$ РГИА ДВ. Ф. Р-2422. Оп. 1. Д. 899. Л. 28.

${ }^{242}$ Там же. Д. 3. Л. 57.

${ }^{243}$ ГАРФ. Ф. Р-393. Оп. 43а. Д. 1104. Л. 8-9; ГАЗК. Ф. Р-27. Оп. 1. Д. 128. Л. 22.

${ }^{244}$ ГАХК. Ф. Р-1962. Оп. 1. Д. 13. Л. 9. 
изучение архивных документов позволяет утверждать, что такие случаи не носили массового характера.

В 1924 г. приказом ЦАУ НКВД РСФСР № 59 внешкольное курсовое обучение сотрудников милиции, должно было осуществляться в объеме 68 часов. На курсах милиционеры должны были изучать юридические дисциплины. Тематика проводимых программ разрабатывалась Управлением Рабоче-крестьянской милиции Дальнего Востока на основе директив из Москвы и утверждалась на заседаниях Дальневосточного революционного комитета по представлению его отдела управления. В целях улучшения качества подготовки кадров к проведению занятий на курсах привлекались работники Наркомата юстиции и прокуратуры. Но на Дальнем Востоке такие курсы проводились эпизодично. Они действовали в мае 1924 г. в Благовещенске, а во всех уездах Амурской губернии, за исключением Зейского, в 1924 г. внешкольная подготовка не велась, осуществлялось инструктирование работников уголовного розыска по вопросам проведения дознания и трудностям советского права ${ }^{245}$. В отчетных докладах милицейского руководства Дальнего Востока о внешкольной подготовке главной причиной ее слабого распространения указывался кадровый голод не позволявший милиционерам выделять время для обучения.

Изменение внутриполитической обстановки в РСФСР, необходимость укрепления законности, способствовали возрастанию роли правоохранительных органов в

245 ГАРФ. Ф. Р-393. Оп. 58. Д. 63. Л. 30; РГИА ДВ. Ф. Р-2460. Оп. 1. Д. 150. Л. 103, 169. 
общественной жизни. Все это позволило милицейскому руководству больше обращать внимание на качество знаний сотрудников органов НКВД. Поэтому другим руководящим документом, по организации курсового обучения, стал приказ ЦАУ НКВД РСФСР № 190 от 12 октября 1925 г., в соответствии с которым на изучение советского права отводилось уже 105 часов (30\% всего времени работы курсов). Курсанты изучали советскую Конституцию в объеме 25 учебных часов, гражданское, уголовное право и уголовный процесс по 20 часов, семейное и земельное право по 10 часов $^{246}$. В соответствии с ним в 1925-1926 гг. в дальневосточных губерниях действовали разнообразные внешкольные курсы подготовки кадров милиционеров со сроком обучения от 2 до 4 месяцев, которые позволили повысить квалификацию около 150 сотрудников. Обучение сотрудников милиции предусматривалось по трем группам. В первую вошли лица, занимавшие должности среднего начальствующего состава и участковых надзирателей. Вторую группу составили сотрудники, занимавшие командные должности младшего состава. Основное внимание при подготовке этих двух групп было обращено на изучение уголовного законодательства и судопроизводства. Занятия с третей группой проводились для младших милиционеров. Кроме изучения специальных нормативных актов, регулирующих

246 Токарева С.Н. Общеюридическая подготовка советских милиционеров в 1920-е годы // Вестник Воронежского института МВД России. 2013. № 3. С. 201. 
деятельность постового милиционера, с ними изучались основы судебной медицины ${ }^{247}$.

В рассматриваемый период впервые обратились к практике внешкольной подготовки волостных милиционеров. Разработка программы курсов их обучения стала предметом междуведомственного совещания весной 1925 г. Его итогом стало утверждение 90-часовой программы курсов для сотрудников волостных отделов милиции. Треть часов, курсовой подготовки, отводилась на изучение правовых дисциплин. В сжатом цикле освещались вопросы обязательственных правоотношений, наследования, прав собственности и актов гражданского состояния. Изучались основные положения земельного права и судопроизводства в гражданском процессе. Значительно большее внимание уделялось уголовному праву и уголовному судопроизводству ${ }^{248}$. Все это свидетельствовало о расширении роли правовых знаний в обществе, отходу от применения права на основе революционного правосознания и необходимости обеспечения правоохранительной деятельности в соответствии с нормами советского законодательства.

В отчетном докладе руководителя милиции Дальневосточной области об итогах внешкольной работы за 1924 г. среди сотрудников милиции отмечалось, что «в Амурской губернии 8 помощников начальников волостных милиций Благовещенского уезда прошли программу 3-недельных краткосрочных курсов при уездном управлении. В Приморской губернии работа по

${ }^{247}$ ГАРФ. Ф. Р-393. Оп. 58. Д. 63. Л. 38.

248 Там же. Оп. 51. Д. 147. Л. 48-49. 
поднятию квалификации работников милиции и ликвидации правовой безграмотности находится в стадии формирования», подготовительный этап планировалось завершить к лету $1925 г^{249}$. Были проведены краткосрочные курсы для милиционеров в Спасском уезде, на которых читались лекции по уголовному праву и процессу $^{250}$. Несмотря на то, что к проведению занятий привлекались практики из числа прокурорских работников, народных следователей и судейского корпуса, «получаемые знания не удовлетворяли всех запросов в современной работе» ${ }^{251}$. Слушатели не усваивали уголовное право и уголовный процесс, гражданское и административное право. Тем не менее, итогом работы стало осуществление комплекса мероприятий, по ликвидации правовой безграмотности среди 81 сотрудника командного состава милиции и 53 младших милиционеров $^{252}$. Оценивая с современных позиций логику преподавания подчеркнем, что изучение специальных отраслей права без знания теоретических положений правовой науки, затрудняет понимание норм касающихся сферы правонарушений. Поэтому не вызывает удивления свидетельства о сложности восприятия курсантами учебного материала.

Летом 1925 г. руководством дальневосточной милиции были подведены итоги внешкольной подготовки сотрудников, организованной на местах. В докладе

\footnotetext{
${ }^{249}$ ГАРФ. Ф. Р-393. Оп. 58. Д. 63. Л. 30-31.

${ }^{250}$ РГИА ДВ. Ф. Р-2460. Оп. 1. Д. 149. Л. 41.

${ }^{251}$ ГАРФ. Ф. Р-393. Оп. 58. Д. 63. Л. 31.

252 Там же. Л. 30 об.
} 
помощника прокурора Забайкальской губернии Бакшта об итогах инспектирования сотрудников милиции отмечено, что милиция ввиду сокращения штатов совершенно перегружена, «работники уездных милиций почти не подготовлены к работе, приходилось проводить инструктирование посещая отделения» ${ }^{253}$. В Приморской губернии ситуация была несколько лучше. В документе об итогах внешкольной работы в Приморье подчеркнуто, что проведены занятия по гражданскому, лесному и земельному праву увеличился состав преподавателей. Однако руководство местной милиции обращало внимание, что только $80 \%$ начальствующего состава посещало организуемые занятия, явка среди среднего командного состава и сотрудников низового аппарата едва достигала $60 \%$. Интерес сотрудников милиции вызвали занятия по уголовно-процессуальному кодексу РСФСР. Они проводились путем совещаний, инструктирования и разъяснений 2 раза в месяц, средний командный состав присутствовал $100 \%$. В уездах организовывались 8часовые занятия по ликвидации правовой безграмотности, на которых присутствовало около $80 \%$ сотрудников милиции. В Амурской губернии занятия удалось провести с сотрудниками Благовещенского, Завитинского и Свободненского уездов. В сентябре 1925 г. впервые были организованы 4-недельные курсы в Петропавловске (Камчатская губерния), которые посещали не только сотрудники милиции, но и частей особого назначения. Всего обучалось 10 чел., т.к. процесс обучения проходил

${ }^{253}$ ГАЗК. Ф. Р-55. Оп. 1. Д. 2. Л. 39-41.

${ }^{254}$ ГАРФ. Ф. Р-393. Оп. 58. Д. 63. Л. 48 об. 
без отрыва от основной работы. Слушатели курсов изучали общеобразовательный и правовой блоки в объеме 106 часов, 6-часовые занятия проводились в форме бесед три раза в неделю. Основное внимание уделялось изучению основ Конституции РСФСР, а также практическому применению норм уголовного и уголовнопроцессуального кодексов, производству дознания 255 . Преподавательский состав для организации изучения общеобразовательных дисциплин назначался камчатским отделом народного образования, а правовые дисциплины проводили представители народного суда, члены коллегии защитников, руководство местной милиции и юрисконсульты губревкома. В отчете об итогах курсового обучения, направленном в центральный аппарат, отмечалось, что ввиду командировок преподавательского состава план занятий полностью выполнить не удалось. Трудности были преодолены и курсы эпизодически работали и в 1926-1927 гг. ${ }^{256}$. Однако основными формами правового просвещения милиционеров оставались коллективные читки газет и политический час ${ }^{257}$.

Начальник дальневосточной милиции Н.С. Тяжелов в своем докладе, направленном в Дальревком и Дальбюро ЦК РКП (б) констатировал, что проведение обучающих курсов для низового аппарата сотрудников весьма затруднено. В связи с «отсутствием в уездах хорошо

255 ГАРФ. Ф. Р-393. Оп. 58. Д. 63. Л. 38об.

256 Пасечник А.Ф. Профессиональное обучение и материальное обеспечение личного состава камчатской милиции в 1920-х гг. // Вопросы истории Камчатки. Вып. 6. Петропавловск-Камчатский, 2012. C. 423-426.

${ }^{257}$ ГАХК. Ф. П-2. Оп. 11. Д. 7. Л. 43. 
подготовленных специалистов, занятостью имеющихся лекторов, а также сильной загруженностью уездных милиционеров, которые не могут посещать даже вечерние занятия ввиду сильной усталости» ${ }^{258}$. Несмотря на перечисленные факты это была более успешная, по сравнению с предыдущими итогами, реализация центральных и региональных директив. Ее воплощение в жизнь стало возможным после реорганизации милицейской службы, пополнения милиции партийными кадрами, проведенной в 1923 г. аттестации личного состава милиции, ужесточения требований к профессиональным знаниям действующих сотрудников. Но и к концу 1926 г. на Дальнем Востоке из-за материально-бытовых проблем, низкой оплаты труда, сохранялась текучка личного состава милиционеров. Так, в Амурском округе она составляла до 51, 1\%, в Николаевском - 58\%, а в органах дознания в целом $65 \%{ }^{259}$. Милицейское руководство отчетливо понимало необходимость реформы системы социального обеспечения милиционеров, изменения подходов к профессиональному росту сотрудников, установления требований первичной профессиональной подготовки сотрудников, пополняющих штат практических подразделений органов НКВД.

Необходимость привлечения на работу в органы милиции людей, преданных идеям советской власти и имевшим опыт борьбы с преступностью актуализировала

${ }^{258}$ ГАРФ. Ф. Р-393. Оп. 58. Д. 63. Л. 48-50.

${ }^{259}$ РГИА ДВ. Ф. Р-2460. Оп. 1. Д. 244. Л. 101; Д. 288. Л. 13; Д. 298. Л. 91. 
разработку системы переподготовки красноармейцев, подлежащих демобилизации. Острый недостаток опытных сотрудников испытывали волостные органы милиции. Поэтому демобилизованные военнослужащие, прежде всего, направлялись на работу именно в волости. В связи с этим в 1923 г. руководство Центрального административного управления (ЦАУ) НКВД РСФСР разработало и разослало на места приказ, регулировавший организацию переподготовки и инструктирования личного состава без отрыва от работы. Предлагалось «использовать Красные уголки и клубы, снабженные литературой по вопросам службы, инструкциями, приказами и т.п.». При этом роль милицейского руководства сводилась «к развитию интереса к службе у подчиненных и даче разъяснений» ${ }^{260}$. Однако выполнение этого документа было затруднительно с одной стороны недостатком юридической литературы, а с другой - eе моральным устареванием. Необходимо подчеркнуть, что в удаленных местностях, например, на Северо-Востоке России, в условиях невозможности отправки квалифицированных сотрудников, организации регулярного школьнокурсового профессионального обучения проведение занятий в юридических клубах и кружках становилось единственной реальной возможностью повышения квалификации действующих милиционеров. Например, в 1924 г. начал работу юридический кружок в Петропавловске. Сотрудники городской милиции, а позднее и органов юстиции, были обязаны посещать занятия по уголовному, гражданскому,

${ }^{260}$ ГАЗК. Ф. Р-27. Оп. 1. Д. 128. Л. 22. 
административному, финансовому праву, а также по судопроизводству, проходившие 3 раза в неделю.

C середины 1920-х гг. демобилизованных военнослужащих готовили на 90-часовых курсах, организованных при милицейских образовательных учреждениях. На Дальнем Востоке такие курсы действовали при Центральной милицейской школе командного состава. Задачами обучения было «сообщение элементарных знаний по милицейской службе и привитие навыков необходимых для обращения с инструкциями и приказами, а также соответствующими статьями Кодекса» ${ }^{261}$. Поэтому объем сообщаемых правовых знаний составлял треть отведенного времени. Количество выпускников было не большим, но и они способствовали замещению вакансий в низовых подразделениях милиции.

Руководство страны на рубеже 1920 - 1930-х гг. значительное внимание уделяло кадровому составу всех государственных структур. В этот период происходило формирование системы нормативных правовых основ необходимых для регулирования подготовки и обучения кадров. Делегаты Второго Всероссийского съезда административных работников, проходившего в Москве в апреле 1928 г. отмечали, что отсутствие преподавательских кадров, программ обучения, а главное - времени, делают невозможным проведение внешкольных занятий на местах с действующими сотрудниками $^{262}$. Несмотря на выдвинутую XV съездом

${ }^{261}$ ГАРФ. Ф. Р-393. Оп. 51. Д. 150. Л. 9.

262 Второй Всероссийский съезд административных работников (23-30 апреля 1928 г.). М., 1929. С. 57. 
ВКП (б) задачу введения в СССР всеобщего обязательного обучения, в РСФСР оставался значительным процент малограмотных и неграмотных милиционеров. Образовательный ценз милиционеров Дальнего Востока к рубежу десятилетий не претерпел существенных изменений: $83,3 \%$ сотрудников имели низшее образование, а $10,5 \%$ - оставались неграмотными ${ }^{263}$. Поэтому сохранялись задачи повышения уровня общего образования милиционеров и распространение первичных правовых знаний среди действующих сотрудников.

1930-е гг. ознаменовались ускорением темпов социалистического развития, что влекло необходимость профессионального обучения работников всех отраслей. Активно развивалось профессиональное техническое образование, возросло количество училищ и техникумов. Повышение уровня профессионального образования населения требовало от сотрудников милиции специальных знаний. В этот период реорганизация системы профессиональной подготовки милицейских кадров продолжилась. Однако оно впервые сопровождалось пересмотром социальных гарантий.

Постановлением ЦИК и СНК СССР «О правовом и материальном положении работников РКМ и уголовного розыска» с февраля 1931 г. на милиционеров и членов их семей были распространены льготы в сфере образования, землепользования и сельского хозяйства, жилья. Создавалась сеть закрытых столовых и пунктов

${ }^{263}$ ГАХК. П-2. Оп. 3. Д. 200. Л. 90; Тихоокеанская звезда. 1928. 23 нояб. 
распределения $^{264}$. Служба милиционеров перестала регулироваться законодательством о труде, на сотрудников распространялись ведомственные нормативные акты, а деятельность профессиональных союзов была свернута. Эти изменения закреплены введенным в действие в августе 1931 г. Временным уставом внутренней службы рабоче-крестьянской милиции. Документ регулировал порядок принятия на службу, перевода, командирования, убытия в отпуск, а также социального обеспечения сотрудников ${ }^{265}$. В конце декабря 1932 г., на основании циркулярного письма «О работе среди членов семей», родственников милиционеров стали привлекать к работе по ликвидации неграмотности и деятельности просветительских кружков ${ }^{266}$. Супруги сотрудников милиции имели первоочередное право на занятие вакансий в хозяйственных службах рабочекрестьянской милиции ${ }^{267}$.

В этот же период организована система изучения морально-деловых качеств сотрудников милиции. В управление рабоче-крестьянской милиции ежеквартально подавались сводки о политическом и моральном состоянии личного состава. Их анализ за 1932-1935 гг.

264 О правовом и материальном положении работников милиции уголовного розыска: постановление ЦИК и СНК СССР от 3 февраля 1931 г. // Собрание законодательства СССР. 1931. № 8, ст. 90.

265 Сборник приказов и циркуляров Главного управления рабочекрестьянской милиции при Совете народных комиссаров РСФСР. 1931. № 1. С. 69-76.

${ }^{266}$ ГАХК. Ф. П-406. Оп. 1. Д. 47.

267 Мигущенко О.Н. Материальное обеспечение деятельности милиции в 20-30-е годы XX в. // История государства и права. 2011. № 14. C. 47. 
свидетельствует о росте политических (сокрытие личной информации о прошлом, связь с арестованными) и уголовных (бандитизм, злоупотребление властью, присвоение или растрата, хищение, халатность) преступлений, увеличении числа антисоветских настроений (отрицательное отношение к политике партии, неудовлетворенность материальным обеспечением) и служебно-бытовых (пьянство, дебош) проступков ${ }^{268}$.

Изучение вынесенных в 1932 г. приговоров свидетельствует, что количество совершенных милиционерами преступлений увеличилось за 1 год в 1,8 раза. Число привлеченных к ответственности в судебном порядке доходило до 24\%, а подвергшихся дисциплинарным взысканиям - 16\% от общего состава сотрудников. Преступность в милицейской среде выражалась в неисполнениях распоряжений начальства, уклонении от службы, побегах, нарушении правил несения службы, появлении в нетрезвом виде на службе, халатности, подлогах и «промотании оружия» ${ }^{269}$.

Социальный срез противоправных действий среди милиционеров показывает, что около половины всех правонарушений совершал рядовой состав большинство из которых служили менее 1 года ${ }^{270}$. Например, милиционер Завитинского районного отделения милиции Ершов, проходивший службу первый год, исполняя

${ }^{268}$ ГАХК. Ф. П-30. Оп. 1. Д. 119. Л. 1-44; Д. 134. Л. 140-163; Ф. Р384. Оп. 4. Д. 6. Л. 108-109, 156; Д. 7. Л. 1; Ф. Р-957. Оп. 1. Д. 6. Л. $21-$ 40; Д. 8. Л. 4-13, 32-47; Оп. 8. Д. 4. Л. 75-77, 84, 104, 117, 119, 136-139.

${ }^{269}$ ГАХК. Ф. Р-384. Оп. 4. Д. 4. Л. 230-235, 279-365, 310.

270 Там же. Д. 6. Л. 109, 181; Д. 7. Л. 1; Ф. Р-957. Оп. 1. Д. 6. Л. $23-$ 40; Д. 8. Л. 3-4, 31-32. 
обязанности по охране арестованных, «ночью ушел с поста и вернулся утром», за это время трое арестованных сбежали $^{271}$. Милиционер Красиков, «будучи пьяным, на посту по охране склада Союззолото, учинил дебош, выбил окна в квартире сторожа, произвел два выстрела, после чего ушел с поста спать». Осужденные к лишению свободы сотрудники милиции, содержавшиеся в хабаровском изоляторе, свободно ходили по городу ${ }^{272}$. Причинами низкого морального уровня среди подчиненных, руководство дальневосточной милиции считало «проникновение классово чуждого элемента, недостаточность партийно-политической и культурномассовой работы, несознательность», а также отсутствие специальных мероприятий по проверке кандидатов на службу в милицию. Для снижения уровня правонарушений предлагалось провести «мобилизацию партийно-комсомольских и политических органов», развивать участие милиционеров в посевных кампаниях, проводить политические занятия с рядовыми сотрудниками ${ }^{273}$. Безусловно, проводимые мероприятия воздействовали на часть сотрудников, однако личный состав постоянно пополнялся, и доля правонарушений незначительно колебалась. По итогам 1933 г. наблюдалась синусоида преступности среди милиционеров, наивысшая точка которой приходилась на летние месяцы. Только за 1933 г. в отношении дальневосточных милиционеров было возбуждено 411 уголовных дел, по которым проходило

${ }^{271}$ ГАХК. Ф. Р-957. Оп. 1. Д. 8. Л. 46.

272 Там же. Ф. Р-384. Оп. 8. Д. 5. Л. 127.

273 Там же. Оп. 4. Д. 9. Л. 14; Д. 5. Л. 186; Оп. 8. Д. 4. Л. 16, 127. 
527 сотрудников. По результатам расследования большая часть уголовных дел была закрыта, но и на основании завершенных 183 дел, 244 чел. привлечено к уголовной ответственности. Наиболее частыми видами преступлений являлись: злоупотребление властью и превышение должностных полномочий, незаконные аресты, обыски и избиения арестованных - по этим статьям было возбуждено 84 дела, обвинялись 110 чел.; по статьям о дискредитации на почве пьянства и дебоша возбудили 66 дел, по которым проходило 100 обвиняемых; за нарушение устава караульной службы было возбуждено 52 дела, среди подозреваемых числилось 55 чел. Наибольшее количество привлекаемых принадлежало к числу рядового состава. Милиционеров ведомственной милиции было 135 чел., государственной милиции - 112 чел., участковых инспекторов - 74 чел., 50 работников оперативных отделов, 23 чел. старшего начальствующего состава и еще 19 начальников и помощников районных управлений милиции. Основная причина виделась в низком уровне квалификации ${ }^{274}$.

Анализ статистических сводок о правонарушениях справедливо свидетельствует, что наиболее часто проступки и преступления совершали милиционеры, не имевшие специального образования. Поэтому огромное внимание стало уделяться повышению образовательного уровня сотрудников. С выходом в начале августа 1930 г. приказа НКВД РСФСР «Об утверждении сетки учебных заведений» была реорганизована профессиональная учеба милиционеров. Расширилось количество внешкольных

${ }^{274}$ ГАХК. Ф. Р-384. Оп. 4. Д. 7. Л. 1. 
занятий. Утвержденный центральным руководством НКВД РСФСР план учебы предполагал обучение на курсах по 90 часов в год. Ведомственным актом устанавливалось проведение занятий «через день в свободное от службы время». Основой преподавания стали практические занятия с милиционерами ${ }^{275}$. Внешкольная подготовка проводилась с 1 октября по 1 мая, не менее 2 часов в неделю. Такой режим работы был обусловлен большой занятостью милиционеров, особенно работающих в сельской местности в весеннелетний период. Программы внешкольной подготовки, разработанные центральным милицейским руководством, предусматривали помимо изучения правовых актов, связанных с деятельностью милиции, строевое и военное обучение ${ }^{276}$. Позднее, в соответствие со спущенным из Центра учебным планом занятия должны были проводиться не менее 3 раз в неделю в свободное от службы время ${ }^{277}$. Однако реалии отличались от директивных указаний. Кадровый голод вынуждал исполнителей искать иные способы распространения правовых знаний среди практиков.

Управлением рабоче-крестьянской

милиции Дальневосточного края ежемесячно организовывались инструкторские совещания с участковыми инспекторами сельской местности. С сотрудниками из отдаленных районов проведение таких совещаний было затруднительным. Так, с

275 ГАХК. Ф. Р-1962. Оп. 1. Д. 13. Л. 33-35.

276 История советской милиции: Советская милиция в период строительства социализма. М., 1977. С. 295.

${ }^{277}$ ГАХК. Ф. Р-1962. Оп. 1. Д. 13. Л. 33. 
милиционерами Сахалина и Камчатки встречи проводились лишь 1-2 раза за навигацию. Ввиду незначительности штатов (1 сотрудник на волость) направление на стационарное обучение было невозможным. Поэтому основным методом повышения квалификации оставалась внешкольная подготовка. Устные и письменные инструктажи милиционеров проводили командированные сотрудники наркомата юстиции. Практиковались вызовы районных руководителей милиции с отчетными докладами, после которых и проводилось инструктирование. А для милиционеров волостей был разработан «вопросник», работа над которым предполагала общеобразовательные знания и знания о милицейской службе, а также вопросы политической информированности. В этой связи широко был распространен «анкетный контроль», широко применялось обсуждение публикаций правового характера из камчатской губернской газеты «Полярная звезда» ${ }^{278}$. В Охотско-Эвенском национальном округе 6 раз в месяц, в вечернее время, проводились беседы с личным составом милиционеров $^{279}$. Конечно, такие меры не позволяли говорить о профессиональной подготовке милиционеров, но они давали возможность распространить правовые знания необходимые практикующим сотрудникам.

Организовывались занятия по строевому обучению, политической и физической подготовке, а также изучению основных вопросов следствия, дознания и административного надзора ${ }^{280}$. Несмотря на проводимую

${ }^{278}$ ГАХК. Ф. П-2. Оп. 1. Д. 86. Л. 11.

279 Там же. Ф. Р-384. Оп. 8. Д. 5. Л. 41.

280 Там же. Оп. 4. Д. 4. Л. 145-146. 
работу, начальник милиции Дальневосточного края в своем отчете по итогам 1931 г. отмечал, что «из общей штатной численности сотрудников 3348 чел., только 4,1\% имели среднее образование, а основная масса имела низшее образование» ${ }^{281}$. В документе отмечалось, что «очень часто приходится сталкиваться с людьми при удовлетворительной подготовке малограмотными и низким общекультурным уровнем» ${ }^{282}$. В резолюция партийного руководства тех лет подчеркивалось, что образовательная подготовка милиционеров должна более жестко контролироваться, а для проведения занятий направлялись квалифицированные специалисты-практики, в том числе и в отдаленные регионы Дальневосточного края. Однако времени для качественного проведения занятий катастрофически не хватало. Усиление бандитизма в северных районах Дальневосточного края и вовсе сводило внешкольные занятия к минимуму.

С лета 1931 г., т.е. после т.н. Мукденского инцидента, на Дальнем Востоке было организовано военное обучение личного состава милиционеров. Практиковался созыв семинаров сотрудников районных отделений, организовывалась проверка политических знаний рядового и начальствующего состава ${ }^{283}$. Занятия с рядовыми проводились силами младшего начальствующего состава. Слабая подготовка командиров, недостаток учебных пособий отражались на качестве проведения занятий. Поэтому, для повышения квалификации младших командиров руководство

\footnotetext{
${ }^{281}$ ГАХК. Ф. Р-384. Оп. 4. Д. 4. Л. 28, 47.

282 Там же. Л. 49.

283 Там же. Оп. 5. Д. 14. Л. 7; Оп. 8. Д. 4. Л. 59-60; Д. 5. Л. 206-207.
} 
дальневосточной милиции предлагало открыть в Хабаровске краевую школу переподготовки начальствующего состава на 100 мест с 3-месячным курсом обучения. Отсутствие финансирования не явилось поводом для отказа от намеченных мероприятий, предложение милицейского начальства было поддержано. Занятия проводились с 15 апреля по 6 июня 1932 г. прошли обучение 100 сотрудников, но успешно сдали испытания лишь $94^{284}$. Тем не менее партийным и региональным руководством результаты учебы были признаны положительными. Дальнейшее существование курсов даже не рассматривалось, ввиду отсутствия средств. Решение задач повышения подготовленности кадров целиком легло на милицейское начальство. По настоянию краевого милицейского начальства не менее 4 раз в 3 месяца с руководящим составом РКМ проводились занятия по милицейской технике, были организованы курсы по подготовке среднего начальствующего состава. Их удалось открыть в Хабаровске с контингентом обучения 50 чел., предполагали открыть межрайонные курсы для среднего начальствующего состава и курсы для оперативного состава, но отсутствие финансовых средств сделало эти планы несбыточными ${ }^{285}$.

В январе 1932 г. вопрос о состоянии кадров милиции Дальневосточного края рассматривался на заседании краевого комитета ВКП (б). В докладе начальника управления милиции был представлен анализ образовательного уровня управленческого состава рабоче-крестьянской милиции ДВК. Согласно обобщенным сведениям «из 105 человек

${ }^{284}$ ГАХК. Ф. Р-384. Оп. 4. Д. 4. Л. 168-169; 230-235.

285 Там же. Л. 1-3, 273. 
руководящего состава высшего образования никто не имеет, 17 чел. со средним образованием, 12 - низшим, а остальные вообще не имеют никакого образования» ${ }^{286}$. В резолюции доклада отмечался «слабый охват школьно-курсовой подготовки личного состава милиции» ${ }^{287}$. Представленные в отчете данные не сильно разнились с общесоюзными. Поэтому в октябре 1932 г. центральное милицейское руководство издало циркуляр «О развитии общеобразовательной работы в органах РК милиции». Согласно ему сотрудники, не имевшие школьной подготовки, обязывались ее получить. Реализация этого документа была особенно актуальной на Дальнем Востоке, где под его действие подпадало более $95 \%$ личного состава ${ }^{288}$. Стоит подчеркнуть, что в этот период сеть специальных милицейских школ, ввиду недостатка финансирования, была сокращена. Краевые (областные) милицейские школы, коих было всего 8, в 1931-1932 гг. сняты с государственного бюджета и переведены на местное финансирование.

Перипетии коснулись и дальневосточной милицейской школы. Поэтому в Дальневосточном регионе школьную подготовку предполагали компенсировать развитием самообразования сотрудников и расширением внешкольной подготовки. Не обошлось без перегибов и формализма. Даже в отдаленных районах Дальнего Востока, где практически отсутствовала возможность проведения систематических занятий с личным составом сотрудников милиции, в силу их малочисленности и территориальной разбросанности

\footnotetext{
${ }^{286}$ ГАХК. Ф. Р-384. Оп. 4. Д. 4. Л. 322.

287 Там же. Л. 8.

${ }^{288}$ Там же. Л. 51.
} 
требовали проводить занятия не менее 6 раз в месяц. При этом предписывалось соблюдать годовой, квартальный и месячные планы проведения практических занятий ${ }^{289}$. Однако в некоторых областях региона, например, в Еврейской автономной области, такие занятия не проводились «и попыток их организации не было» ${ }^{290}$. Несмотря на предпринимаемые усилия, Краевое управление милиции НКВД по Дальневосточному краю, проведя инспекцию управлений констатировало, что на местах «не осуществляется обучение навыкам службы, не практикуется созыв семинаров работников уголовного розыска и начальников отделений милиции» ${ }^{291}$. Последовавшие за выводами санкции коснулись лишь низового милицейского руководства и кардинально ситуацию не изменили.

Изменение государственных взглядов на юридическое образование привело к очередной кампании по распространению правовых знаний. В ноябре 1934 г. приказом НКВД СССР для работников рабочекрестьянской милиции введен «Общий технический минимум». Предполагалось, что изучение нормативных актов повысит образовательный уровень сотрудников и увеличит юридическую грамотность милиционеров. Сотрудники рядового и начальствующего состава милиции до 1 июня 1935 г. были обязаны изучить и сдать зачет по знанию видов и особенностей наружной милицейской службы, правилам задержания и привода в отделы милиции нарушителей порядка, правил наложения

${ }^{289}$ ГАХК. Ф. Р-384. Оп. 8. Д. 5. Л. 41-42.

${ }^{290}$ Там же. Д. 4. Л. 16.

${ }^{291}$ Там же. Оп. 5. Д. 14. Л. 7-9. 
взысканий на месте обнаружения нарушения и нарушителя, а также общих принципов паспортизации населения. Кроме того, весь личный состав обязывался изучить законодательство СССР и ведомственные правовые акты ${ }^{292}$. Участковые инспектора рабочекрестьянской милиции сдавали технический минимум на знание административного законодательства, уполномоченные уголовного розыска - знание уголовного, уголовно-процессуального кодексов, а также правил производства следствия, правила прокурорского надзора по наблюдению за производством следствия ${ }^{293}$. По итогам проведенной кампании в Дальневосточном крае технический минимум сдали лишь 111 чел., т.е. около 41\% от общего числа ${ }^{294}$. Прежде всего такой низкий процент был связан с необходимостью разноплановой подготовки, т.к. минимум включал в себя политический, военный, специальный милицейский и общий циклы. С другой стороны, - в Дальневосточном регионе специальная литература по-прежнему оставалась недоступной широкому кругу обучающихся.

При проведении занятий по техническому минимуму случались и крайности в действиях самих преподавателей. Например, в феврале 1935 г. в Уссурийской области при проведении занятий со старшим и средним начальствующим составом по теме «Убийство», начальник отделения Н.С. Попович обратился к слушателям с вопросом: «Вот убийство Кирова, как вы думаете, на

${ }^{292}$ ГАХК. Ф. Р-384. Оп. 8. Д. 4. Л. 69-70.

293 Там же.

${ }^{294}$ ГАХК. Ф. Р-1962. Оп. 1. Д. 34. Л. 106. 
какой почве оно совершено?». Далее отвечая на свой вопрос сказал: «Убийство Кирова совершено из корыстных целей». В результате полемики, не желая признавать «контрреволюционную» версию убийства, он сделал вывод, что «Киров убит на почве политической» 295 . Последствия не заставили себя долго ждать. В короткие сроки об этом инциденте узнали структуры органов безопасности, после чего начались процедуры допросов и поиска компрометирующих материалов.

В целях улучшения работы с личным составом с 1936 г. в системе НКВД СССР был образован Отдел кадров. В его задачи входили подбор, расстановка, выдвижение, перемещение и увольнение сотрудников милиции. Сотрудники кадровых отделов занимались профессиональной подготовкой и переподготовкой, повышением квалификации личного состава, регулировали вопросы материального и правового обеспечения милиционеров. Все это позволило организовать единый общесоюзный подход к расстановке, обучению, воспитанию и материальному обеспечению кадров. Повышение престижа милицейской службы было закреплено введением в 1936 г. специальных званий, присваиваемых в соответствии с наличием специального образования, стажа службы, уровнем квалификации и служебной аттестации ${ }^{296}$.

${ }^{295}$ ГАХК. Ф. Р-957. Оп. 1. Д. 8. Л. 34.

296 Собрание законов СССР. 1936. № 36, ст. 316а. Документ устанавливал и предельные сроки службы. Так, до 45 лет могли служить милиционеры в звании от сержанта до лейтенанта, до 50 лет от старшего лейтенанта до майора, а до 55 лет имеющие звание старшего майора и выше. 
В соответствии с руководящими документами НКВД СССР с лета 1936 г. с рядовыми милиционерами проводились еженедельные занятия. План их проведения и тематика утверждалась приказом наркомата внутренних дел СССР. Документами регламентировалось изучение юридического блока. Проводились занятия о служебных правах милиционеров, изучались виды административных взысканий, порядок составления административных протоколов, основания личного задержания и порядок проведения оперативных мероприятий. Особое внимание отводилось изучению темы «Борьба с преступностью и паспортизация». Внимание сотрудников обращалось на теоретические проблемы преступности, а также практические меры борьбы с хулиганством, беспризорными и безнадзорными детьми, расхитителями социалистической собственности. В условиях продолжающегося сокращения штатов милиции, имелись, хоть и кратковременные, но положительные примеры их расширения. Так, например, если в 1935 г. штат АяноМайского отделения милиции составлял 5 чел., то к 1938 г. оно было реорганизовано в Управление со штатом 15 чел. Ocобое внимание было уделено увеличению числа участковых инспекторов и младших милиционеров, работающих в сельской местности. Правда, к январю 1939 г. личный состав милиции снова достиг 9 чел. ${ }^{297}$. И все же такие случаи носили единичный характер.

В конце 1930-х гг. для усовершенствования профессиональных знаний, умений и навыков появилась новая форма проведения внешкольных занятий - лагерные

${ }^{297}$ ГАХК. Ф. Р-384. Оп. 8. Д. 43. Л. 1. 
сборы сотрудников милиции. Такие практические занятия, с начальствующим составом РКМ Хабаровского и Приморского краев состоялись весной 1940 г. На сборах руководители органов внутренних дел изучали вопросы текущей политики, организацию охраны общественного порядка и борьбы с уголовной преступностью. Проводимые мероприятия по повышению уровня профессиональных знаний сотрудников милиции без отрыва от работы не давали положительных результатов. На краевом партийном совещании, состоявшемся в конце 1940 г, отмечалось, что «милиционеры плохо знают законы, поэтому сами хулиганят и плохо ведут следствие». В резолюции указано о нецелесообразности практической работы с сотрудниками, полагали, что реальным выходом должно стать только укрепление кадров ${ }^{298}$.

Начиная со второй половины 1920-х гг. внешкольной подготовке милиционеров стало уделяться большее внимание. Одной из причин этого была необходимость обучения и повышения квалификации огромного числа дальневосточных милиционеров, а ввиду неразвитости системы школьно-курсового обучения внешкольные формы подготовки приобрели важное значение. Кроме того, невозможность организации школ и курсов милиции в отдаленных районах Дальнего Востока также выдвигала внешкольную подготовку на первый план.

Реализация внешкольной подготовки была сопряжена с некоторыми трудностями. Так как основную массу сотрудников милиции составляли представители крестьянства, зачастую имевшие низкий образовательный

${ }^{298}$ ГАКХ. Ф. П-2. Оп. 1. Д. 511. Л. 8-9; Ф. П-35. Оп. 1. Д. 511. Л. 1-27. 
уровень, качество внешкольной подготовки оставалось не высоким. Не способствовали повышению квалификации низкий уровень материального обеспечения милиционеров и высокий процент текучести кадров.

Активизация работы по развертыванию правового образования, начатая в начале 1930-х гг. по инициативе руководства наркомата юстиции РСФСР, не обошла стороной и милицейские структуры. Мероприятия, проводимые советским правительством в системе кадровой работы в органах милиции, позволили к концу 1930-х гг. несколько повысить образовательный и профессиональный уровень части сотрудников. Однако оставалась актуальной проблема правового обучения милиционеров из отдаленных и труднодоступный районов Дальнего Востока. Главной причиной слабого распространения внешкольной подготовки выступал недостаток ее финансирования.

Таким образом, организация внешкольной подготовки милиционеров была вызвана объективными условиями снижения финансирования специализированных образовательных учреждений милиции в середине 1920-х гг. Несмотря на отсутствие подготовленных кадров инструкторов, значительное количество малограмотных и неграмотных милиционеров, практика еe реализации, в основном, имела положительные результаты. Достижением проведенной работы стоит считать повышение уровня профессиональной подготовки дальневосточных милиционеров к концу 1930-х гг.

Эффективность правового воспитания зависела не только от содержания, но и от способов сообщения 
населению информации. Основными формами правового просвещения и воспитания населения являлись консультационно-информационная и экспозиционнодемонстрационная. Новыми способами правового воспитания стало использование агитационного фарфора, лаковой миниатюры, текстиля, почтовой открытки. Все это позволяло формировать у населения советскую идентичность.

В целом, работа по правовому просвещению сотрудников государственных органов и правовому воспитанию населения Дальнего Востока проведенная в 1922-1941 гг. имела свои специфические черты:

- проводилась через агитацию и пропаганду советского законодательства;

- в ее ходе применялись современные материальнотехнические средства;

- основное внимание было направлено на работу среди сельского населения;

- осуществлялась в сжатые сроки. 


\section{ЗАКЛЮЧЕНИЕ}

Период 1917-1941 гг. это уникальная эпоха складывания и развития системы правового просвещения. Специфика его содержания определялась составом населения и идеологическими ориентирами. В советский период материальная, организационная и методическая поддержка государства способствовала распространению мероприятий, направленных на формирование у населения страны правовых и моральных ценностей, стойких убеждений в необходимости следования правовым нормам.

Правовое просвещение на Дальнем Востоке России носило последовательный характер, включало в себя деятельность многих ведомств, в основном было ориентировано на сельских жителей и учитывало специфику исторического развития региона. Все это позволило к началу Великой Отечественной войны сформировать у жителей Дальневосточного региона советское правовое сознание, положительно повлиявшее на дальнейшее общественное развитие.

В целом, изучение становления и развития правового просвещения на Дальнем Востоке в 1917-1941 гг. свидетельствует, что при осуществлении реформирования системы просвещения необходимо опираться на исторический опыт, накопленный в регионе. Его учет предостерегает от слепого копирования, автоматичного переноса на региональную почву образовательных концепций реализованных или реализуемых в образовательных учреждениях центральной России и за рубежом. 


\section{СПИСОК ИСПОЛЬЗОВАННОЙ ЛИТЕРАТУРЫ}

VII Дальневосточная краевая конференция РКП (б) (16-20 XI 1925 г.): стенографический отчет. - Хабаровск, 1925.

Амфитеатров, Г. Методика подготовки и чтения лекций / Г. Амфитеатров. // Советская юстиция. - 1941. - № 5. С. 6-8; № 6. - С. 11-13.

Бакалейников, П.С. Становление камчатской милиции (1918-1922 гг.) / П.С. Бакалейников. // История социалистического строительства на Камчатке. - Владивосток : Издательство ДВНЦ АН СССР, 1979. - С. 119-122.

Бакшутов, С.Н., Орнацкая, Т.А., Шабельникова, Н.А. Дальневосточная милицейская школа в государственной системе профессионального образования (1918-2011гг.). / С.Н. Бакшутов, Т.А. Орнацкая, Н.А. Шабельникова. Владивосток : Изд-во Дальневост. федерал. ун-та, 2017. 226 с.

Беляева, Н.А., Шабельникова, Н.А., Милежик, А.В., Усов, А.В., Никонов, К.О. Информационные ресурсы фондов РГИА ДВ и ГАХК по истории полиции и милиции Дальнего Востока России (1860-1922) / Н.А. Беляева, Н.А. Шабельникова, А.В. Милежик, А.В. Усов, К.О. Никонов. - Владивосток: ВФ ДВЮИ МВД России, 2019. - 60 с.

Березкина, Н.И., Гуменюк, Ф.И., Ткалич, А.П. От неграмотности ко всеобщему среднему образованию. Исторический очерк развития образовательной и профессиональной школы в 1917-1987 годах / Н.И. Березкина, Ф.И. Гуменюк, А.П. Ткалич. - Владивосток: б.и., 1991. - 102 с.

Берман, Я. О правовом образовании / Я. Берман. // Советское государство. - 1936. - № 5. - С. 115-124. 
Блонский, П.П. Избранные педагогические сочинения в 2-х томах / П.П. Блонский. -М. : Педагогика, 1979. - Т. 1. - 304 с.

Болдырев В.Г. Из пережитого // Сибирские огни. - 1922. - №№ 5-6; 1924. - № 1.

Бранденбургский, Я. Вопросы переподготовки судебных кадров / Я. Бранденбургский. // Советская юстиция. - 1936. - № 8. - С. 70-73.

Бранденбургский, Я.Н. Просто законность или революционная законность? / Я.Н. Бранденбургский. // Еженедельник советской юстиции. - 1922. - № 31-32. - С. 1-2.

Венцов С., Белинский С. Красная гвардия. - М., 1924.

Воробьев, Р.А. Советская милиция Приамурья (1917-1925 гг.) / Р.А. Воробьев. - Хабаровск: Хабаровская высшая школа МВД CCCP, 1989. $-96 \mathrm{c}$.

Всесоюзное совещание по вопросам юридического образования // Социалистическая законность. - 1938. - № 7. - С. 99-101.

Второй Всероссийский съезд административных работников (23-30 апреля 1928 г.). Сокращенная стенограмма. - М.: Издательство НКВД РСФСР, 1929. - 135 с.

Генкина, Э.Б. Курс истории СССР / Э.Б. Генкина. - М., 1938.

Герцензон, А. Юридическое образование / А. Герензон. // Советская юстиция. - 1941. - № 2. - С. 10 - 13.

Гинс, Г.К. Сибирь, союзники и Колчак. Поворотный момент русской истории. 1918 - 1920. / Г.К. Гинс. - М.: Айрис - Пресс, 2008. - 672с.

Гойхбарг, А.Г. Основы частного имущественного права. Очерки / А.Г. Гойхбарг. - М. : Красная новь, 1924. - 136 с.

Гойхбарг, А.Г. Пролетарская революция и гражданское право / А.Г. Гойхбарг. // Пролетарская революция и право. 1918. - № 1. - С. 12-19. 
Голунский, С. Учебный план и программы юридических институтов / С. Голунский. // Советская юстиция. - 1941. - № 1. - С. 12-14.

Гольдман, В.С. Из истории организации школ и курсов милиции РСФСР в 1917-1925 годах / В.С. Гольдман. // Труды Высшей школы МООП СССР. - М: НИ и РИО ВШ МООП СССР, 1968. - Вып. 20. - С. 80-98.

Городецкий Е.Н. Рождение Советского государства. - М.: Наука, 1987. $-412 \mathrm{c}$.

Горяева, Т.М. Радио России: политический контроль советского радиовещания в 1920-1930-х гг. Документированная история / Т.М. Горяева. - М.: Проспект, 2000. - 412 с.

Гродзинский, М. К методике заочного юридического образования / М. Гродзинский. // Социалистическая законность. - 1941. - № 2. - С. 21-22.

Дальний Восток России в период революций 1917 года и гражданской войны. - Владивосток: Дальнаука, 2003. 632 с. (История Дальнего Востока России. Т. 3. Кн. 1).

История Дальнего Востока России. Т. 3. Кн. 3. Дальний Восток СССР: 1941-1945 гг. / под общ. ред. чл.корр. РАН Н.Н. Крадина, отв. ред. Г.А. Ткачева / Коллектив авторов: Крадин Н.Н., Галлямова Л.И., Беляева Н.А. и др. Владивосток : Дальнаука, 2020. - 944 с.

История Дальнего Востока России. Т. 3. Кн. 2: Дальний Восток России в эпоху советской модернизации: 1922 - начало 1941 года / Коллектив авторов: Галлямова Л.И., Сергеев О.И., Проскурина Л.И. и др. - Владивосток : Дальнаука, 2018. - 656 с.

Дальревком. Сб. постановлений. - Чита : б.и., 1922. 
Дальсовнарком. 1917-1918 гг. Сб. док. и материалов. Хабаровск : Хабаровское кн. изд-во, 1969. - 376 с.

Декреты Советской власти. - М.: Госполитиздат, 1957-1986.

Директивы ВКП (б) и постановления Советского Правительства о народном образовании. Сб. док. за 19171947 гг. : Приложение к журналу «Советская педагогика» / Сост. Н.М. Болдырев. Вып. 2. - М.-Л.: Изд-во Академии педагогических наук РСФСР, 1947. - 304 с.

Директивы ВКП (б) по вопросам просвещения: вопросы народного просвещения в Основных директивах съездов, конференций, совещаний Центрального комитета и Центральной контрольной комиссии ВКП (б). - М.-Л.: Наркомпрос РСФСР-ОГИЗ, 1931. - 496 с.

Дисциплинарный устав Рабоче-Крестьянской милиции. - М.: ОГИЗ, 1931. - 40 с.

Доклад Крыленко на VI совещании руководящих работников органов юстиции // Советская юстиция. - 1932. - № 6-7. - С. 12-27.

Долудь. Школьная и курсовая сеть юридического образования / Долудь. // Советская юстиция. - 1938. - № 5. - С. 40-42.

Евдеева, Н.В. Правосознание и правопонимание: диалектика взаимодействия / Н.В. Евдеева. // Современное право. - 2007. № 7. - C. 48-52.

Ермаков, В.Т. Исторический опыт культурной революции в СССР / В.Т. Ермаков. - М.: Наука, 1968. - 136 с.

Жуков, В.Н. Марксистская социология права первых лет советской власти : М.А. Рейснер, П.И. Стучка, Е.Б. Пашуканис / В.Н. Жуков. // Право и государство : теория и практика. - 2014. -№ 1 (109). - С. 43-53. 
Жуков, В.Н. Право, государство, закон: трактовка советских юристов 1920-х годов / В.Н. Жуков. // Аграрное и земельное право. - 2015. - № 7 (128). - С. 20-27.

Закрепить успехи избирательной кампании по выборам в Верховный Совет РСФСР. Сб. материалов в помощь пропагандисту и агитатору. Ростов -на - Дону, 1938;

Звягин, С.П. Правоохранительная политика А.В. Колчака / С.П. Звягин. - Кемерово: Кузбассвузиздат, 2001. - 352 с.

Звягинцев, Е.А. Словарь внешкольнаго образованія / Е.А Звягинцев. - М. : Издательство журнала «Народный учитель», 1918. $-80 \mathrm{c}$.

Зимина, В.Д. Белое движение и российская государственность в период Гражданской войны / В.Д. Зимина. - Волгоград: Родина, 1997. - 441 с.

Иезуитов, В., Резунов, М. Назревшая реформа / В. Иезуитов, М. Резунов // Советское государство и революция права. -1930. - № 3. - С. 142-146.

Из истории социалистического и коммунистического строительства на Дальнем Востоке СССР (1917-1975 гг.) Владивосток: ДВНЦ АН СССР, 1976. - 110 с.

Инструктивное письмо № 8 Дальневосточного краевого Отдела народного образования. - Хабаровск, 1927. - С. 40-62.

Инструкция по организации самостоятельной учебной работы студентов-заочников. - М.: НКЮ, 1938. - 4 с.

Иорданский, Н.Н. Основы и практика социального воспитания / Н.Н. Иорданский. - М. : Работник просвещения, 1923. - 190 с.

Иоффе, О.С. Развитие цивилистической мысли в СССР: в 2-х частях: Ч. 1. / О.С. Иоффе. - Л. : Издательство Ленинградского университета, 1975. - 160 с. 
Исаева, Т.С., Сонин, В.В. Из истории развития советской государственности на Дальнем Востоке. 1922-1926. / Т.С. Исаева, В.В. Сонин. - Владивосток: ДВГУ, 1974. - 80 с.

История гражданской войны в СССР / Под ред. М. Горького, В. Молотова и др. М.: Госполитиздат, 1936. -742 с.

История Дальнего Востока СССР. - Владивосток: Дальнаука, 1976. - 542 с.

История советской милиции: в 2-х тт. / Биленко С.В., Гольдман В.С., Косицин А.П. и др. / Под ред. Щелокова Н.А. Т. 1. Советская милиция в период строительства социализма. М.: б.и., 1977. - 346 с.; Т. 2. Советская милиция в период строительства социализма (1936-1977). - М. : б.и., 1977. - 338 с.

Кабаненко, М.С. Деформация теоретического (доктринального) правосознания: период становления советского права / М. С. Кабаненко. // Юридическая наука и практика. - 2011. - № 7. - С. 37-43.

Кабо, Е.О. Очерки рабочего быта (Опыт монографического исследования рабочего быта) / Е.О. Кабо - M., 1928. - 142 c.

Ким, М.П. Коммунистическая партия - организатор культурной революции в СССР / М.П. Ким. - М.: Наука, 1955. - 143 c.

Кожевина, М.А. «Неттелбалдтова система» или Чему учили первых российских правоведов / М.А. Кожевина. // Научный вестник Омской академии МВД России. - 2008. № 1. - С. 34 - 40 .

Козлов Заочное юридическое образование / Козлов. // Советская юстиция. - 1940. - № 1. - С. 12-14.

Козуров, В.В. Правовые основы организации и деятельности народной милиции Дальневосточной 
республики (1920- 1922 гг.) / В.В. Козуров. // 50 лет СССР и развитие советского государства и права (Материалы науч.-практ. конфер. декабрь 1972). - Омск: Омская ВШМ МВД СССР, 1973. - С. 153-169.

Колемасов, В.Н. Организация профессиональной подготовки сотрудников милиции России в 1920- е годы / В.Н. Колемасов. // Новый юридический журнал. - 2012. № 2. - С. 175-179.

Коммунистическая партия Советского Союза в резолюциях и решениях съездов, конференций и пленумов ЦК (1898-1986). В 16 тт. - М.: Политиздат, 1984.

КПСС во главе культурной революции в СССР. - М. : Наука, 1972. - 743 с.

Краев, М.А. Победа колхозного строя в СССР / М.А. Краев. - М.:Госполитиздат, 1954. - 152 с.

Крапивина, Н.С. Система подбора, расстановки, профессиональной подготовки и воспитания кадров советской милиции в 1930-е годы / Н.С. Крапивина. // Ученые записки Санкт-Петербургского им. В.Б. Бобкова филиала Российской таможенной академии. - 1997. - № 2 (4). - С. 220-237.

Красногорский, М. Готовить кадры юристов темпами военного времени / М. Красногорский. // Социалистическая законность. - 1941. - № 7-8. - С. 14-16.

Крупская, Н.К. Педагогические сочинения в 10 томах: Т. 2. Общие вопросы педагогики: Организация народного образования в СССР / Н.К. Крупская. - М.: Издательство Академии педагогических наук, 1958. - 735 с. 
Крыленко, Н.В. Советское правосудие. Суд и прокуратура в СССР / Н.В. Крыленко. - М.: Юридическое издательство НКЮ, 1937. - 19 с.

Кузнецов, М.С. Борьба партийных организаций Дальнего Востока за становление советской культуры (1922-1927 гг.) / М.С. Кузнецов - Томск: Академкнига, 1978. - 412 с.

Культурное строительство на Дальнем Востоке (19171941 гг.) Док. и материалы. - Владивосток: Дальнаука, 1982. - 482 c.

Лебедев, П.И. Советское искусство в период иностранной военной интервенции и гражданской войны / П.И. Лебедев. - М.-Л.: Соцгиз, 1949. - 76 с.

Лебедев, В.М. Выступление Председателя Верховного суда Российской Федерации В.М. Лебедева / В.М. Лебедев. // Российский судья. -2009. - № 1. - С. 6-13.

Ленин В.И. Задачи союзов молодежи (Речь на III Всероссийском съезде Российского Коммунистического Союза Молодежи 2 октября 1920 г.) // Полн. собр. соч. T. 41. - С. 298-318.

Ленин, В.И. Войско и революция / В.И. Ленин // Полн. собр. соч. - Т. 12. - С. 111-114.

Ленин, В.И. Две тактики социал-демократии в демократической революции / В.И. Ленин // Полн. собр. соч. - T. 11. - С. 3-131.

Ленин, В.И. Наказ по вопросам хозяйственной работы, принятый IX Всероссийским съездом Советов 28 декабря 1921 г. / В.И. Ленин // Полн. собр. соч. - Т. 44. - С. 335-338.

Ленин, В.И. Начало революции в России / В.И. Ленин // Полн. собр. соч. - Т. 9. - С. 201-204. 
Ленин, В.И. О государстве и праве: сб. произведений в 2-х тт. / В.И. Ленин. - М.: Издательство юридической литературы, 1958.

Ленин, В.И. О задачах Наркомюста в условиях новой экономической политики (письмо Д.И. Курскому) / В.И. Ленин // Полн. собр. соч. - Т. 44. - С. 396-400.

Ленин, В.И. Очередные задачи Советской власти / В.И. Ленин // Полн. собр. соч. - Т. 36. - С. 165-208.

Лобов А.А. Культурное строительство на Дальнем Востоке. / А.А. Лобов // Тихоокеанская звезда. - 1928. - 30 мая.

Лопухов, Р. Неотложные задачи юридического заочного образования / Р. Лопухов // Социалистическая законность. 1938. - № 11. - C. 58-59.

Лукин, Ю.Ф. Из истории сопротивления тоталитаризму в СССР (20-80-е годы). / Ю.Ф. Лукин - М.: Наука, 1992. - 336 с.

Луначарский, А.В. О классовой школе / А.В. Луначарский // А.В. Луначарский о народном образовании. Сборник / ред.: Н.К. Гончаров, Н.А. Константинов, Ф.Ф. Королев. - М: Академия педагогических наук РСФСР, 1958. - С. 95 - 118.

Луначарский, А.В. О воспитании и образовании : Избр. статьи / Под ред. А. М. Арсеньева / А.В. Луначарский. - М. : Педагогика,1976. - 634 с.

Лыкова, Е.А. Культурные преобразования в дальневосточной деревне в годы гражданской войны и военной иностранной интервенции (1918-1922 гг.) / Е.А. Лыкова // Социально-культурное развитие СССР (советский период): сб. науч. тр. - Владивосток, 1986. - С. 5-14.

Ляскина, Н.В. Работа по профилактике правонарушений и детской беспризорности среди несовершеннолетних в школах 
Приморского края (1941-1945 гг.) / Н.В. Ляскина // Современная научная мысль. - 2019. - № 6. - С. 103-107.

Ляскина, Н.В. Деятельность милиции Приморского края по борьбе с беспризорностью и преступностью несовершеннолетних в годы Великой Отечественной войны : историографический аспект / Н.В. Ляскина // Клио. - 2020. - № 11 (167). - С. 18-24.

Макаренко, А.С. О воспитании: сборник / А.С. Макаренко. - М. : Политиздат, 1985. - 255 с.

Макеев, А. Формирование системы профессиональной подготовки кадров милиции в 1930-е гг. особенности кадровой политики в регионах (историко-правовой аспект) / А. Макеев. // Юридическая мысль. - 2002. - № 3 (9). - С. 9 - 21.

Мартынов, М.И. Единый сельскохозяйственный налог 1926/1927 года в условиях Дальне-Восточного края (пособие для докладчиков, пропагандистов, сельской интеллигенции и беспартийного крестьянского актива). / М.И. Мартынов. Хабаровск: Издательство «ТОЗ», 1926. - 30 с.

Матузов, Н.И., Малько, А.В. Теория государства и права / Н.И. Матузов, А.В. Малько. - М. : Юрист, 2003. - 512 с.

Медынский, Е.М. Просвещение в СССР / Е.М. Медынский. -М. : Учпедгиз, 1955. - 239 с.

Мигущенко, О.Н. Материальное обеспечение деятельности милиции в 20-30-е годы XX в. / О.Н. Мигущенко. // История государства и права. - 2011. № 14. - С. 45-48.

Миловидов, А.С. Коммунистическая нравственность и военно-патриотическое воспитание / А.С. Миловидов. М. : Знание, 1979. -64 c.

Минц, И.И. История Великого Октября: в 3 тт. / И.И. Минц. - М.: Госполитиздат, 1967-1973. 
Модельный закон о просветительской деятельности: принят 20 мая 2016 г. на сорок четвертом пленарном заседании Межпарламентской Ассамблеи государств участников СНГ [электронный ресурс] // https://narodirossii.ru/ [дата обращения 4 мая 2019 г.]

Мороз, Е.В. Отечественное правопонимание в 1920-х гг. (некоторые аспекты проблемы) / Е.В. Мороз // Право и образование. - 2012. - № 1. - С. 146-155.

Мухина, Т.Г. История и перспективы развития дополнительного профессионального образования в России / Т.Г. Мухина // Приволжский научный журнал. 2013. - № 3 (27). - С. 123-128.

Народное образование в СССР. Общеобразовательная школа. Сб. док. 1917-1973. - М.: Педагогика, 1974. - 560 с.

Народное просвещение на Дальнем Востоке (Отчет ОНО Дальнего Востока за 1924/25 уч. год). - Б.м.: Б.и., 1925. - $112 \mathrm{c}$.

Николаев, П.Ф. Школы-резервы милиции СССР в 19211925 гг. / П.Ф. Николаев. // Научные труды. Научные труды Омской ВШМ МВД СССР. - 1969. - Вып. 5. - С. 347-358.

Ниязов, С. Культармейцы. Приморскому комсомолу - 50 лет. / С. Ниязов // Красное знамя. - 1970. - 27 окт.

Некрытый, В.В. История органов внутренних дел на Дальнем Востоке России в исследованиях и библиографии/ В.В. Некрытый // Россия и Китай: история и перспективы сотрудничества: материалы IX международной научно-практической конференции. Вып. 9. Ч. 1 / Отв. ред. О.А. Шеломихин. -Благовещенск : Изд- во БГПУ, 2019. - С. 200-207. 
О бесплатной юридической помощи в Российской Федерации: федер. закон № 324-ФЗ от 21 ноября 2011 г. // Российская газета. - 2011. - 23 нояб.

О выборах в Верховный Совет РСФСР. Сб. материалов. Хабаровск, 1938.

О подготовке научных и научно-педагогических работников: постановление СНК СССР от 13 января 1934 г. // Известия ЦИК и ВЦИК СССР. - 1934. - 14 янв.

О популяризации советского законодательства: постановление Агитпропотдела ЦК ВКП (б) // Еженедельник советской юстиции. - 1927. - № 16.

О работе РКП в деревне (Постановление ЦК РКП во исполнение решений ХІІ Съезда РКП) - Тюмень : Б-и, 1923. $-15 \mathrm{c}$.

О системе заочного обучения: постановление СНК РСФСР от 3 марта 1931 г. // Бюллетень Народного комиссариата по просвещению РСФСР. - 1931. - № 10, ст. 150.

Об образовании: федер. закон № 273-Ф3 от 29 декабря 2012 г. // Собрание законодательства Российской Федерации. № 53 (ч. I). - 31 дек. 2012, ст. 7598.

Об организации в органах прокуратуры Российской Федерации работы правовому просвещению и правовому информированию: приказ Генерального прокурора Российской Федерации от 2 августа 2018 г. [электронный ресурс]// Генеральная прокуратура Российской Федерации. Режим доступа: www. https://genproc.gov.ru [дата обращения 19 марта 2019 г.]

Об основах системы профилактики правонарушений в Российской Федерации: федер. закон № 182-Ф3 от 23 июня 2016 г. // Российская газета. - 2016. - 28 июня. 
Озеров, М. Просветительная работа по кооперации. / М. Озеров. - М-Л.: Центральное товарищество «Кооперативное издательство», 1926. - 64 с.

Олейник, И.И. Организация и результаты юридической подготовки работников правоохранительных органов в Советском государстве (1917-1941 гг.) / И.И. Олейник. // Вестник Владимирского юридического института. - 2008. - № 2 (7). - С. 259-264.

Орнацкая, Т.А. Особенности подготовки юристов в Приморье в первый период гражданской войны / Т.А. Орнацкая // Теория и практика общественного развития. - 2015. - № 19. - С. 139-141.

Орнацкая, Т.А. К вопросу о моральных устоях дальневосточных милиционеров в 1920-1922 гг. / Т.А. Орнацкая // Чтения памяти А.А. Сидоренко: материалы регион. заоч. науч.-практ. конфер. (Благовещенск, 30 ноября 2016 г.): периодический сборник. Вып. 3. / отв. ред. А.В. Кузин. - Благовещенск: Изд-во БГПУ, 2016. - С. 119-124.
Орнацкая,
T.A.
Кадровая
политика
B правоохранительных органах (на примере советской милиции Дальнего Востока в 1920-1930-е годы) / Т.А. Орнацкая // Исторический журнал: научные исследования. - 2016. - № 4. - С. 441-449.

Орнацкая, Т.А. Кадровое обеспечение органов милиции на Дальнем Востоке России (ноябрь 1922 - март 1926 гг.) / Т.А. Орнацкая // Научные ведомости БелГУ. Серия «История. Политология». - 2016. - № 15. - Вып. 39 (сентябрь). - С. 136-141.

Орнацкая, Т.А., Хитин М.С. Организация внешкольной работы с дальневосточными милиционерами 
в середине 1920-х - 1930-е годы / Т.А. Орнацкая, М.С. Хитин // Гуманитарные науки и образование. - 2016. - № 2 (26) (апрель-июнь). - С. 150-154.

Орнацкая, Т.А. Правовая подготовка сотрудников юстиции и милиции в 1917-1920-е годы (на материалах Восточной Сибири и Дальнего Востока) / Т.А. Орнацкая // «Революция 1917 г. и Гражданская война в УралоСибирском регионе»: материалы Всерос. круглого стола, посвященного 100-летию Великой Российской Революции и 95-летию окончания Гражданской войны (7 декабря 2017 г.) / под ред. Д.Н. Маслюженко. - Курган: Изд-во Курганского гос. ун-та, 2017. - С. 189 - 197.

Орнацкая, Т.А. К вопросу о юридической подготовке кадров правоохранительных структур «белых» правительств в Восточной Сибири и на Дальнем Востоке в 1918-1920 гг. / Т.А. Орнацкая // История: факты и символы. - 2017. - № 1 (10). - С. 118-128.

Орнацкая, Т.А. Проблемы комплектования дальневосточной милиции в 1920-е годы / Т.А. Орнацкая // Дальний Восток России на перекрестке эпох [электронное научное издание]: сборник научных трудов / редкол. : Ф.Е. Ажимов [и др.] ; отв. ред. С.М. Дударёнок, М.А. Тулиглович ; Дальневосточный юрид. ин-т МВД России. - Хабаровск: РИО ДВЮИ МВД России, 2017. - 1 электрон. опт. диск (CD-R). - C. 215-218.

Орнацкая, Т.А. Становление и развитие школьнокурсового обучения юристов на Дальнем Востоке в 19221941 гг. / Т.А. Орнацкая // Клио. - 2018. - № 1. - С. 100-108.

Орнацкая, Т.А. Правовая подготовка сотрудников милиции в 1917-1920-х годах (на материалах Восточной Сибири и 
Дальнего Востока) / Т.А. Орнацкая // 300 лет на страже закона и правопорядка [электронное научное издание]: материалы Всерос. науч.-практ. конф. (19-20 апреля) / редкол.: А.А. Андреев [и др.] ; Дальневост. юрид. ин-т МВД России. Хабаровск: РИО ДВЮИ МВД России, 2018. Режим доступа: https://mvd.ru/upload/site134/folder_page/012/627/311/300_let_na _strazhe_zakona_i_pravoporyadka_ENI.pdf - C. 86-90.

Орнацкая, Т.А. Становление кадровой работы в милиции Дальневосточной республики / Т.А. Орнацкая // Девятые Гродековские чтения. Материалы межрегион. науч.-практ. конфер, посвящённой 100 -летию начала Гражданской войны в России. - Хабаровск: Хабаровский краевой музей им. Н.И. Гродекова, 2018. - Т. ІІ. - С. 78-82.

Орнацкая, Т.А. Флагман подготовки милицейских кадров на Дальнем Востоке (об обучении юристов в начале 1920-х гг.) / Т.А. Орнацкая // Гуманитарные науки и образование. - 2018. - № 1. - С. 148-153.

Орнацкая, Т.А. Юридическая подготовка на Дальнем Востоке в 1917-1938 гг.: современная историография (на материалах по истории антибольшевистских сил) / Т.А. Орнацкая // Вестник Хакасского государственного университета им. Н.Ф. Катанова. - 2018. - № 23. - С. 81-83.

Орнацкая, Т.А., Цуканов, С.С., Судебные учреждения Дальневосточной республики: организационное строительство и подбор кадров / Т.А. Орнацкая, С.С. Цуканов // Клио. - 2019. - № 1. - С. 60-64.

Орнацкая, Т.А. Организационные основы строительства органов советской милиции и проблемы их реализации на Дальнем Востоке (октябрь 1917 - начало 1920 гг.) / T.А. Орнацкая // Гуманитарий: актуальные проблемы 
гуманитарной науки и образования. - 2019. - Т. 19. - № 3 (47). - C. 274-282.

Орнацкая, Т.А. Правовое просвещение дальневосточников в ходе предвыборной кампании 1938 г. / Т.А. Орнацкая // Чтения памяти профессора Александра Александровича Сидоренко: материалы регион. заоч. науч.-практ. конфер. (Благовещенск, 30 ноября 2019 г.): периодический сборник. Вып. 6 / отв. ред. А. В. Кузин. Благовещенск: Издательство БГПУ, 2019. - С. 217-221.

Орнацкая, Т.А. Категории «просвещение» и «образование» в отечественной юридической науке / Т.А. Орнацкая // Проблемы высшего образования: материалы XVII междунар. науч.-метод. конфер. Хабаровск: Тихоокеанский государственный университет, 2019. - C. 122-124.

Орнацкая, Т.А. Милиция Дальнего Востока начала 1920-х гг.: от революционного правосознания к правовому просвещению / Т.А. Орнацкая // Первые гуманитарные чтения. - Владивосток: ВФ ДВЮИ МВД России, 2020. C. 262-269.

Парфенов (Алтайский), П.С. Гражданская война в Сибири. 1918-1920 / П.С. Парфенов. - М. : Новь, 1925. - 142 с.

Пасечник, А.Ф. Профессиональное обучение и материальное обеспечение личного состава камчатской милиции в 1920-х гг. / А.Ф. Пасечник. // Вопросы истории Камчатки. - Вып. 6. - Петропавловск-Камчатский: «Новая книга», 2012. - С. 416-447.

Певцова, Е.А. Правовое воспитание и формирование правового сознания в России: история и современность / Е.А. Певцова. // Журнал российского права. -2003. - № 9. - С. 39-44. 
Певцова, Е.А. Правовое воспитание: вопросы теории и практики / Е.А. Певцова. - М.: Международный юридический институт, 2013. - 296 с.

Певцова, Е.А. Современные подходы юристов к вопросу соотношения дефиниций «правовая культура», «правовое воспитание», «правовое образование» / Е.А. Певцова. // Основы государства и права. -2001. - № 6. - С. 61-69.

Певцова, Е.А. Юридическое образование: формирование правовой культуры общества / Е.А. Певцова. // Фундаментальные и прикладные исследования кооперативного сектора экономики. -2012. - № 5. - С. 119-122.

Певцова, Е.А., Соколов, Н.Я. Правовое просвещение в России: состояние, проблемы и перспективы развития / Е.А. Певцова, Н.Я. Соколов. - М. : Проспект, 2019. - 272 с.

Педагогическая энциклопедия / Под ред. А.Г. Калашникова. Тт. 1,3. - М., 1930.

Первый Совдеп: документы и материалы о Петропавловском Совете рабочих и крестьянских депутатов. - Петропавловск-Камчатский: Дальневосточное книжное издательство, 1967. - 143 с.

Петров, А.В. К вопросу о правовом обеспечении организации и деятельности милиции Временного правительства и «белых» правительств Урала и Сибири / А.В. Петров. // Вестник Пермского университета. Юридические науки. - 2012. - № 1. - С.35-41.

Пинкевич, А.П. Педагогика: в 2 тт. / А. П. Пинкевич. М. : Работник просвещения, 1924-1925.

Пишон. Союзническая интервенция на Дальнем Востоке и в Сибири. - М.-Л., 1925. 
Покровский, М.Н. Русская история в самом сжатом очерке / М.Н. Покровский. - М., 1920-1923.

Покровский, М.Н. Избранные произведения в четырех книгах / М.Н. Покровский. - Кн. 4. - М. : Мысль, 1967. - 640 с.

Постановление Агитационно-пропагандистского бюро ЦК ВКП (б) о популяризации советского законодательства // Еженедельник советской юстиции. - 1927. - 28 апр.

Постановления IX Всероссийского съезда Советов. М.: Гос. Изд-во юридической литературы, 1921. - 364 с.

Правила приема в правовые школы - М.: Издательство НКЮ СССР, 1938. - 8 c.

Правила приема во Всесоюзную заочную правовую академию на 1938/1939 учебный год - М.: НКЮ СССР, 1938. $-24 \mathrm{c}$.

Правила приема во Всесоюзную заочную правовую академию на 1939/1940 учебный год - М. : НКЮ СССР, 1939. $-16 \mathrm{c}$.

Примерная программа бесед для изучения «Положения о выборах» в краевые, окружные, районные, городские, сельские и поселковые Советы депутатов трудящихся РСФСР. - Омск, 1939.

Пропаганда и агитация в решениях и документах ВКП(б). (1900-1946 гг.) / Сост. Е. Д. Ворошилова, С. М. Зорина - М.: Госполитиздат, 1947. - 590 с.

Протоколы III Всероссийского съезда деятелей советской юстиции, с приложениями резолюций Съезда. М.: Народный комиссариат юстиции, 1927. - 156 с.

Резолюции V Всероссийского съезда деятелей советской юстиции. 10-15 марта 1924 г-М.: НКЮ, 1924. - 20 с. 
Резолюция VI совещания руководящих работников юстиции по докладу Н.В. Крыленко «Об очередных задачах органов юстиции и содокладу т. Нюриной «О методах работы, контроле исполнения и служебной дисциплине» утвержденная коллегией НКЮ 25. II. 1932 г. // Советская юстиция. - 1932. - № 6-7. - С. 27-34.

Резолюция пленарного заседания Всесоюзного совещания по подготовке кадров при Институте советского строительства и права от 12 января 1930 г. // Советское государство и революция права. - 1930. - № 2. - С. 159-161.

Рейснер, М.А. Право. Наше право. Чужое право. Общее право / М.А. Рейснер. - М.-Л.: Госиздат, 1925. - 276 с.

Решения партии и правительства по хозяйственным вопросам (1917-1967 гг.) - М: Политиздат, 1967. - 783 с.

Ройблат, О.В. От всеобщего образования «взрослых» к неформальному образованию взрослых в современный период / О.В. Ройблат. // Социальные отношения. - 2012. № 1 (4). - С. 5-10.

Ростовский, И. Правовое просвещение и изба-читальня: материалы и их проработка для шести занятий (руководство для юридических бюро, кружков и справочных столов). / И. Ростовский. - М. : Юридическое издательство НКЮ РСФСР, 1927. - 84 с.

Сакач Пять лет работы Московского Краснознаменного юридического института им. П.И. Стучка / Сакач. // Советская юстиция. - 1936. -№ 28. - С. 12-13.

Санчев, В. Очередная задача Наркомюста / В. Санчев. // Еженедельник советская юстиция. - 1922. - № 11. - С. 7. 
Сборник декретов и постановлений рабочекрестьянского правительства по народному образованию М. : Наркомпрос, 1920. - 26 см.

Сборник приказов и циркуляров Главного управления рабоче-крестьянской милиции при Совете народных комиссаров РСФСР. 1931-1932. - М. : б.и., 1932.

Сборник приказов прокуратуры Союза ССР, действующих на 1 декабря 1938 г. / Сост.: Д.И.Орлов, Б.И. Солерс; Под ред.: А.Я. Вышинского - М.: Юрид. издво НКЮ СССР, 1939. - 279 с.

Семенов, Г.М. О себе. Воспоминания, мысли и выводы. 19041921 гг. / Г.М. Семенов. - М.: Центрполиграф, 2007. - 304 с.

Сизонов, К.П. Основы советского права и этапы его развития / К.П. Сизонов. - М. : Государственное издательство «Советское законодательство», 1933. - 64 с.

Синиченко, В.В., Карнович, С.А. Становление милицейского образования в Восточной Сибири в 20-х годах XX века / В.В. Синиченко, С.А. Карнович // Социально-гуманитарные проблемы деятельности ОВД. 2015. - № 1 (72). - С. 65-76.

Снигирева, М.В. Общественные ресурсы в педагогических технологиях правового просвещения. Автореф. дис. ... кандидата пед. наук. / М.В. Снегирева. Екатеринбург, 2009.

Собрание постановлений правительства СССР. - М. : б.и., 1938-1991 гг.

Собрание постановлений правительства СССР. - М.: б.и., 1938-1941 гг.

Собрание постановлений правительства СССР. - М., 19381991 гг. 
Собрание узаконений и распоряжений правительства ДВР.- Чита :б.и., 1921- 1922. - Ч.1.- 1921; Ч.2. - 1922.

Собрание узаконений и распоряжений правительства за 1917-1918 гг. - М.: б.и., 1942. - 1483 с.

Собрание узаконений и распоряжений правительства за 1919 г. - М.: Книга по требованию, 2011. - 886 с.

Собрание узаконений и распоряжений Рабочего и Крестьянского правительства РСФСР. - М.: Управление делами СНК СССР, 1917-1938.

Собрание узаконений и распоряжений РабочеКрестьянского Правительства СССР. - М.: Управление делами СНК СССР, 1922-1937.

Совещание в Прокуратуре Союза ССР с районными следователями // Социалистическая законность. - М., 1936. № 7 (июль). - С. 73-83.

Сонин, В.В. Великий Октябрь и становление советской государственности на Дальнем Востоке (1917-1922) / В.В. Сонин. - Владивосток: Издательство ДВГУ, 1987. - 264 с.

Сонин, В.В. Становление Дальневосточной республики, 1920-1922 / В.В. Сонин. - Владивосток: Издательство Дальневосточного университета, 1990. - 347 с.

Спешилова, Е.В. Деятельность сельских культурнопросветительных учреждений Приморья в 1923-1925 гг. / Е.В. Спешилова // Гуманитарные исследования в Восточной Сибири и на Дальнем Востоке. - 2018. - № 1. - С. 73-77.

СССР в период восстановления народного хозяйства (19211925 гг.) / Под ред. А.П. Кучкина. - М.: Наука, 1955. - 440 с.

Статистический ежегодник 1923-25 гг. Ч. 1. Хабаровск: Б.и., 1925. 
Степанов, M.M. Особенности милицейского образования в России в годы гражданской войны (19181920 гг.) / М.М. Степанов. // Ленинградский юридический журнал. - 2011. - № 1. - С. 101-108.

Строгович, М. О юрминимуме и юридической грамотности / М. Строгович. // Социалистическая законность. -1936 . - № 2. - С. 67-68.

Стучка, П. Постановка нашей работы / П. Стучка. // Советское государство и революция прав. -1930 . - № 1112. - C. 50-57.

Стучка, П. Старый и новый суд / П. Стучка. // Правда. 1918. - 2 янв.

Судариков, Н., Финкельштейн, Б. Пути юридического образования / Н. Судариков, Б. Финкельштейн. // Советская юстиция. - 1941. - № 3. - С. 12-15.

Тарасов - Родионов, И. Повышение квалификации народных следователей / И. Тарасов-Родионов. // Социалистическая законность. - 1936. - № 11. - С. 50-54.

Токарева, С.Н. Общеюридическая подготовка советских милиционеров в 1920-е годы / С.Н. Токарева. // Вестник Воронежского институга МВД России. - 2013. - № 3. - С. 199-202.

Трайнин, А.Н. О революционной законности / А.Н. Трайнин. // Право и Жизнь. - 1922. - № 1. - С. 5-8.

Три года советского строительства в Дальневосточном крае. К первому дальневосточному краевому съезду советов рабоче-крестьянских и красноармейских депутатов: отчет Дальревкома за 1922-25 год / Под ред. М.П. Копытина. - Хабаровск: Б.и., 1926. - 120 с.

Ундервич, В. Борьба за суд пролетарской диктатуры в первые месяцы Октябрьской революции / В. Ундервич. // 
Советское государство и революция права. -1931 . - № 7. С. $58-76$; -№ 8 . - С. $58-79$.

Устрялов, Н.В. 1919-й год. Из прошлого. / Н.В. Устрялов // Русское прошлое. Историкодокументальный альманах. - 1993. - № 4. - С. 194-288.

Филиппова, Л.Е. Формирование образовательных учреждений НКВД в период становления советской власти как часть общей кадровой политики правоохранительных органов / Л.Е. Филиппова. // Вестник Владимирского юридического института. - 2007. - № 1 (2). - С. 104-107.

Флеров, В.С. Дальний Восток в период восстановления народного хозяйства / В.С. Флеров. - Томск: СО РАН, 1973. -146 с.

Ходасевич, А.П. Милиция таежного края. Очерк. / А.П. Ходасевич. - Хабаровск: Хабаровское книжное издательство, 1969. - 159 с.

Центральные заочные курсы по правовому образованию при Московском институте Советского права: положение и правила приема на заочное обучение на 1932 учебный год. - М.: НКЮ РСФСР, 1932. - 13 с.

Ципкин, Ю.Н. Антибольшевистские режимы на Дальнем Востоке России в период гражданской войны (1917-1922 гг.) / Ю.Н. Ципкин - Хабаровск: Изд-во ХГПУ, 2003. - 68 с.

Цуканов, С.С. Дальневосточный революционный комитет: цели, задачи, структура / С.С. Цуканов, Т.А. Орнацкая // История государства и права. - № 3. - 2010. - С. 31-35.

Цуканов, С.С. Военно-политическая обстановка на Дальнем Востоке в 1923-1926 гг. / С.С. Цуканов, Т.А. Орнацкая // Исторические, философские, политические и юридические науки, культурология и искусствоведение. Вопросы теории и практики. - 2011. - № 8 (14) - С. 207-209. 
Цуканов, С.С. Военная реформа 1924-1925 гг. глазами японского разведчика / С.С. Цуканов // Военно-исторический журнал. - 2011. - № 4. - С. 29-37.

Цуканов, С.С. Деятельность Дальневосточного революционного комитета и его роль в развитии региона (1922-1926 гг.) / С.С. Цуканов. - Хабаровск : ХПИ ФСБ России, 2011. - 178 с.

Цуканов, С.С. Социально-политическая обстановка на Дальнем Востоке России после гражданской войны и интервенции / С.С. Цуканов // Чтения памяти профессора А.А. Сидоренко: материалы регион. науч.-практ. конфер. Благовещенск: Изд-во БГПУ, 2015. - С. 148-154.

Цуканов, С.С. Аспекты нормативно-правового регулирования патриотического воспитания в системе Вооруженных Сил РФ / С.С. Цуканов // Общество: политика, экономика, право. 2016. - № 4. - С. 92-94.

Шабанова, И.К. От права пролетарского к праву социалистическому: метаморфоза советских правовых установок / И.К. Шабанова. // Академический вестник. 2013. - № 1 (23). - С. 78-87.

Шабельникова, Н.А. Милиция в борьбе с преступностью на Дальнем Востоке России (1922-1930 гг.) / Н.А. Шабельникова. - Владивосток: Издательство Дальнаука, 2002. - 544 с.

Шабельникова, Н.А., Бакшутов, С.Н. Формирование системы профессионального обучения кадров милиции на Дальнем Востоке России в 1920-е гг. / Н.А. Шабельникова, С.Н. Бакшутов // Теория и практика общественного развития. -2015 . - № 21. - С. 182-185. 
Шабельникова, Н.А. Деятельность правоохранительных органов по борьбе с преступностью на дальнем Востоке России в 1920-е гг. / Н.А. Шабельникова. - М.: Проспект, 2016. - 144 с.

Шабельникова, Н.А. Правоохранительные органы в системе правопорядка на Дальнем Востоке России в 1922-1930 гг. / Н.А. Шабельникова. // Вестник Дальневосточного юридического институга МВД России. - 2017. - № 3 (40). - С. 10-18.

Шабельникова, Н.А. Финансовое и материальное обеспечение сотрудников дальневосточной милиции в 1920-е гг. (к 100-летию образования рабоче-крестьянской милиции) / Н.А. Шабельникова. // Клио. - 2018. - № 1 (133). - С. 60-68.

Шабельникова, Н.А. Милиция Дальнего Востока России (1922-1930-е гг.): исторический опыт организации и деятельности / Н.А. Шабельникова. - Хабаровск : ДВЮИ МВД России, 2018. - 354 с.

Шабельникова, Н.А., Жадан, А.В. На страже закона: дальневосточная милиция в годы Великой Отечественной войны / Н.А. Шабельникова, А.В. Жадан // Исторические чтения на Лубянке: отечественные спецслужбы в войнах и вооруженных конфликтах XX в.: материалы XXIII междунар. науч. конфер. - М., 2019. - С. 343-350.

Шабельникова, Н.А. Великая Победа в памяти поколений: Вторая мировая война в современной дальневосточной историографии / Н.А. Шабельникова. // Клио. 2019. № 1 (145). C. $36-42$.

Шабельникова, Н.А. На страже правопорядка: история органов внутренних дел России в современной дальневосточной историографии / Н.А. Шабельникова. // Клио. 2020. № 5 (161). С. 20-27. 
Шабельникова, Н.А., Миилежик, А.В., Усов, А.В. Формирование профессионального образования сотрудников органов внутренних дел на Дальнем Востоке России: учебное пособие. / Н.А. Шабельникова, А.В. Милежик, А.В. Усов. - Владивосток: Изд-во Дальневост. Федерал. ун-та, 2020. - 92 с.

Шапиро, М.Л. Харбин, 1945 / М.Л. Шапиро // Память : Ист. сб. - Нью-Йорк, 1978. - Вып. 1. - С. 3-92.

Шарапова, Э.А. От внешкольного к дополнительному образованию: историко-педагогический аспект / Э.А. Шарапова. // Профессиональный проект: идеи, технологии, результаты. - 2015. - № 1 (8). - С. 97-101.

Шеронов, В.С. Становление профессиональной подготовки кадров милиции / В.С. Шеронов. - Хабаровск : ДВЮИ МВД РФ, 2000. - 28 с.

Шиндялов, Н.А. Первые шаги по пуги социализма (1922-1926) / Н.А. Шиндялов. - Благовещенск: Кн. изд-во, 1972. - 142 с.

Эратов, Л. К ликвидации правовой безграмотности / Л. Эратов. // Еженедельник советской юстиции. - 1922. - № 8. - С. 8-9.

Юридическое образование в СССР // Советская юстиция. - 1941. - № 16. - С. 1-4.

Янковский, М. За нового человека. (О борьбе молодежи за культуру) / М. Янковский. - Л.: Новь, 1928. - 142 с. 


\section{СПИСОК СОКРАЩЕНИЙ}

ВП ПОЗУ - Временное правительство Приморской областной земской управы

ВЦИК - Всероссийский центральный исполнительный комитет

ГПО (Госполитохрана) - Государственная политическая охрана Дальневосточной республики

ГУ РКМ (Главмилиция) - Главное управление Рабоче-Крестьянской милиции

Дальбюро ЦК РКП (б) - Дальневосточное бюро Центрального комитета Российской коммунистической партии (большевиков)

ДВК - Дальневосточный край

ДВР - Дальневосточная республика

ДРК (Дальревком) - Дальневосточный революционный комитет

ДСНК (Дальсовнарком) - Дальневосточный совет народных комиссаров

МВД - Министерство внутренних дел

Наркомпросс - Народный комиссариат по просвещению

НКВД - Народный комиссариат внутренних дел

НКЮ - Народный комиссариат юстиции

НРА ДВР - Народно-революционная армия Дальневосточной республики

ОГПУ - Объединенное государственное политическое управление

РККА - Рабоче-крестьянская Красная армия

РКМ - Рабоче-Крестьянская милиция 
РЛКСМ - Российский ленинский коммунистический союз молодежи

РСФСР - Российская Советская Федеративная Социалистическая Республика

СМИ - средства массовой информации

СНК - Совет народных комиссаров

СССР - Союз Советских Социалистических Республик

СУ РСФСР - Собрание узаконений Российской Советской Социалистической Республики

ЦАУ НКВД - Центральное административное управление Народного комиссариата внутренних дел

ЦК ВКП(б) - Центральный комитет Всероссийской коммунистической партии (большевиков)

ЦК РКП(б) - Центральный комитет Российской коммунистической партии (большевиков) 


\section{ОГЛАВЛЕНИЕ}

Введение

Глава 1. Правовое просвещение: теоретический аспект 35

Глава 2. Этапы становления советской системы 44 правового просвещения

Глава 3. Организационные формы и содержание правового просвещения населения Дальнего Востока Глава 4. Правовое просвещение в системе профессиональной подготовки сотрудников дальневосточных государственных органов

Глава 5. Формирование правовой культуры дальневосточных милиционеров

Заключение

Список литературы

Список сокращений 


\title{
ИСТОРИЧЕСКИЙ ОПЫТ ПРАВОВОГО ПРОСВЕЩЕНИЯ НА ДАЛЬНЕМ ВОСТОКЕ РОССИИ (1917-1941 гг.)
}

\author{
Монография
}

\author{
Подписано в печать 21.11.2020 г. \\ Формат 60×84 / 16. Усл. печ. л.11,04. \\ Тираж 500 (1-й завод 1-30). Заказ 21-11.
}

Дальневосточный федеральный университет

690922, Приморский край, г. Владивосток, о. Русский, п. Аякс, 10.

Отпечатано в Дальневосточном федеральном университете 690922, Приморский край, г. Владивосток, о. Русский, п. Аякс, 10.

(Типография Издательства ДВФУ, 690091, г. Владивосток, ул. Пушкинская, 10) 